\title{
The Potential for Distributed Generation in Japanese Prototype Buildings: A DER-CAM Analysis of Policy, Tariff Design, Building Energy Use, and Technology Development (English Version)
}

\author{
(この報告書の日本語版は「LBNL-56359 Japanese」で閲覧できる)
}

Principal Authors

Nan Zhou, Chris Marnay, Ryan Firestone, Weijun Gao, Masaru Nishida

Ernest Orlando Lawrence Berkeley National Laboratory

1 Cyclotron Road, MS 90R4000

Berkeley CA 94720-8136

October 2004

This work was supported by the Japan Kyushu Industrial Technology Center. 



\section{Preface}

This effort represents a first application of methods and tools developed to chart a path that can lead us to a robust distributed power system. While these tools have been crafted in the U.S., the paradigm shift that is reinventing power systems is global, and with this effort the first step is taken towards applying skills developed here internationally. 



\section{Table of Contents}

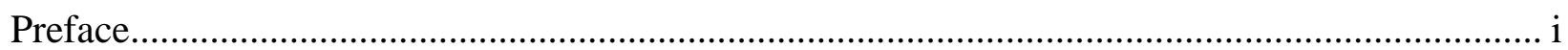

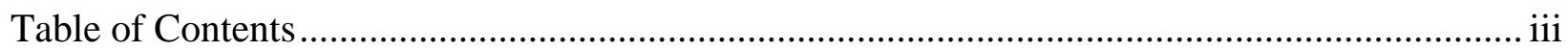

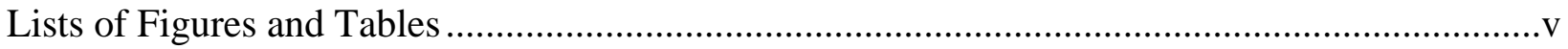

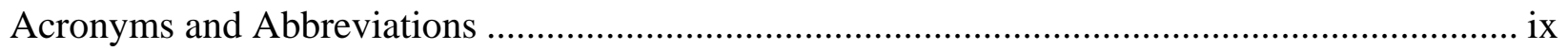

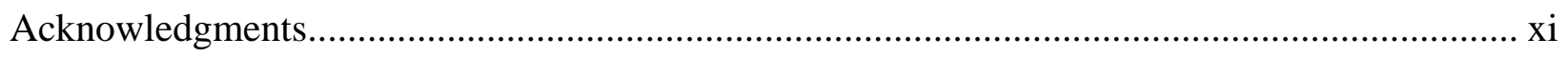

Executive Summary ........................................................................................................ xiii

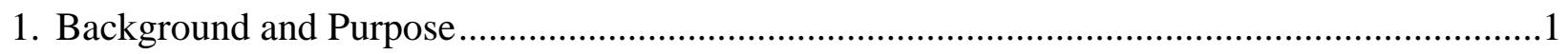

2. Distributed Energy Resources Customer Adoption Model ...................................................3

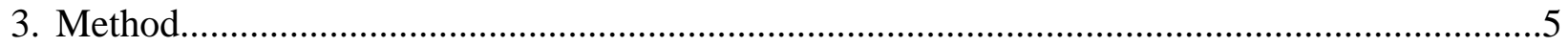

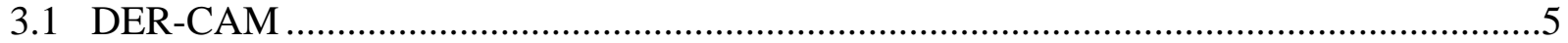

3.2 Estimation of Hourly Energy Consumption ................................................................5

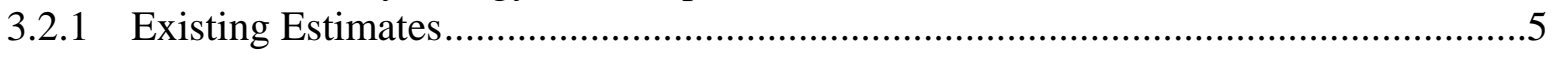

3.2.2 Building Loads from DOE-2 Simulation......................................................6

3.2.3 Comparison of Three Load Data Sources...........................................................

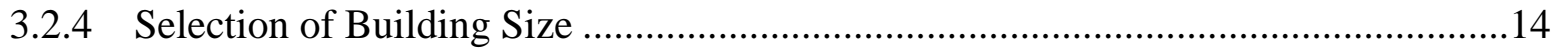

3.3 Comparison of Utility Tariffs in Japan and the U.S. ..............................................15

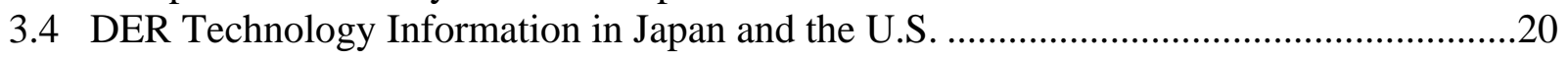

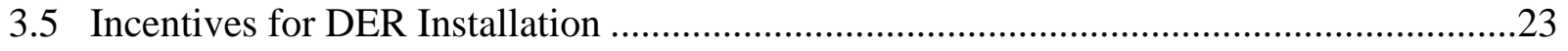

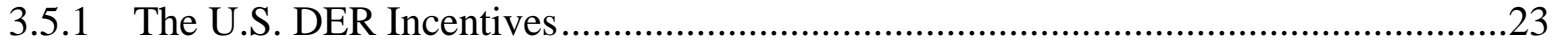

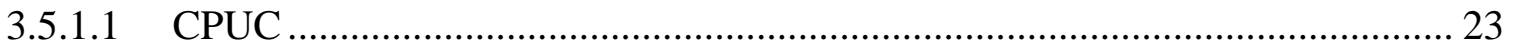

3.5.1.2 New York State Funding for Energy Efficiency and DER ............................ 24

3.5.1.3 Climate Change Fuel Cell program .......................................................... 25

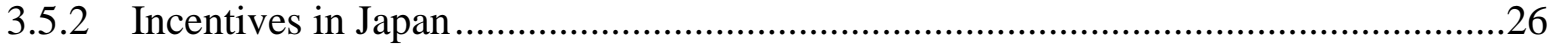

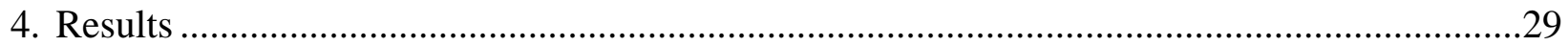

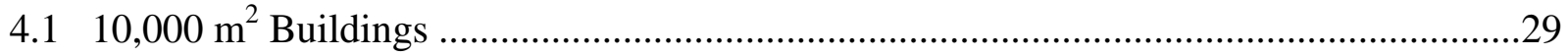

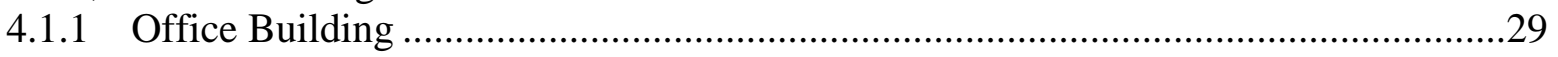

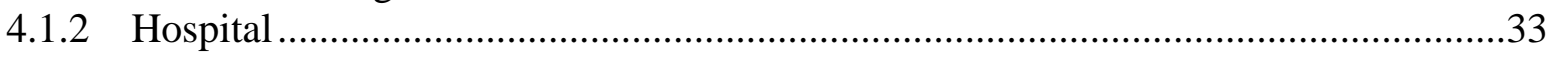

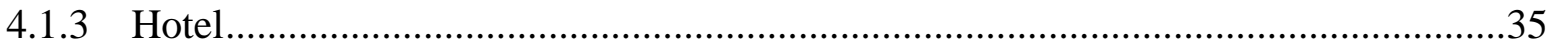

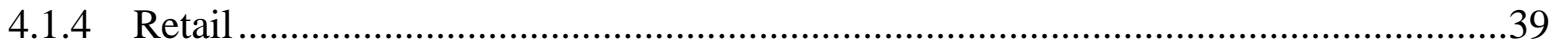

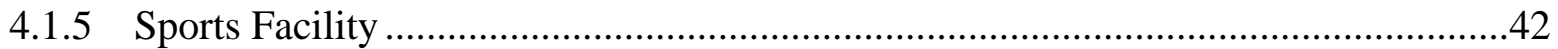

4.1.6 Conclusions for $10,000 \mathrm{~m}^{2}$ Buildings .........................................................45

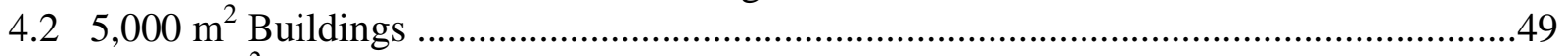

4.3 10,000 $\mathrm{M}^{2}$ Buildings with Unsubsidized Technology Costs ..........................................52

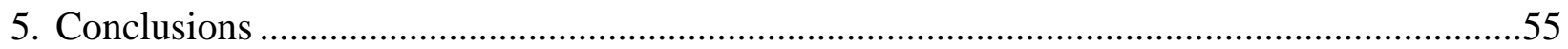


The Potential for Distributed Generation in Japanese Prototype Buildings: English Version

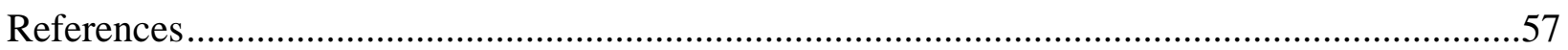




\section{Lists of Figures and Tables}

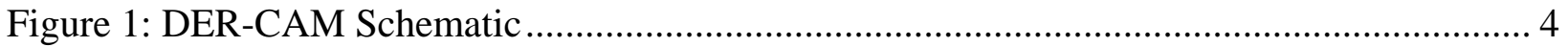

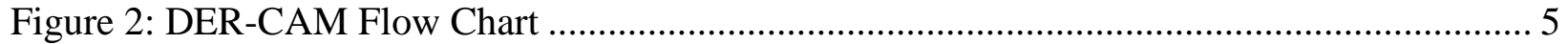

Figure 3: Office July Electricity Load from DOE-2 Simulation ................................................ 8

Figure 4: Office July Cooling Electricity Load from DOE-2 Simulation ................................... 8

Figure 5: Office January Space Heating Load from DOE-2 Simulation ..................................... 8

Figure 6: Office January Hot Water Load from DOE-2 Simulation ....................................... 8

Figure 7: Electricity Only Loads from DOE-2 Simulation.................................................... 9

Figure 8: Electricity Only Loads from Kyushu Intensity (1997) ........................................... 9

Figure 9: Electricity Only Loads from Japan Intensity (2002) ............................................. 9

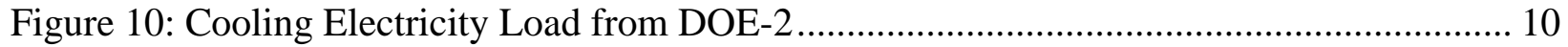

Figure 11: Cooling Electricity Load from Kyushu Intensity (1997) ........................................ 10

Figure 12: Cooling Electricity Load from Japan Intensity (2002) ........................................... 11

Figure 13: Heating Load from DOE-2 ........................................................................... 11

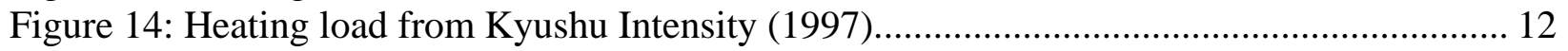

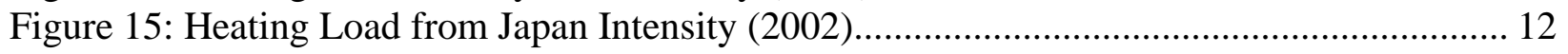

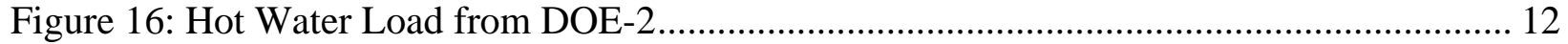

Figure 17: Hot Water Load from Kyushu Intensity (1997) ................................................... 13

Figure 18: Hot Water Load from Japan Intensity (2002) ........................................................ 13

Figure 19: Distribution of Average Construction Floor Area by Building Type ........................ 15

Figure 20: Characteristics of Buildings in the Kyushu Area ................................................... 15

Figure 21: Japanese Electric Utility Service Territories ....................................................... 16

Figure 22: Comparison of turnkey CHP costs in Japan and the U.S. ..................................... 22

Figure 23: Office Building January Electricity Loads ........................................................ 30

Figure 24: Office Building January Electricity Provisions with CHP System .......................... 30

Figure 25: Office Building July Electricity Loads.............................................................. 31

Figure 26: Office Building July Electricity Provision with CHP ......................................... 31

Figure 27: Office Building January Natural Gas Loads ...................................................... 31

Figure 28: Office Building January Natural Gas Load Provisions with CHP ............................ 31

Figure 29: Office Building Annual Carbon Emissions for the Three DER-CAM Scenarios ....... 32

Figure 30: Office Building Annual Fuel Consumption for the Three DER-CAM Scenarios ...... 32

Figure 31: Hospital January Electricity Load .................................................................. 34

Figure 32: Hospital January Electricity Load Provision with CHP ......................................... 34

Figure 33: Hospital July Electricity Load...................................................................... 34

Figure 34: Hospital July Electricity Load Provision with CHP .............................................. 34

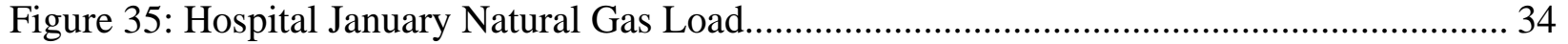

Figure 36: Hospital January Natural Gas Load Provision with CHP ........................................ 34

Figure 37: Hospital Annual Carbon Emissions ................................................................. 35

Figure 38: Hospital Annual Fuel Consumption ................................................................. 35

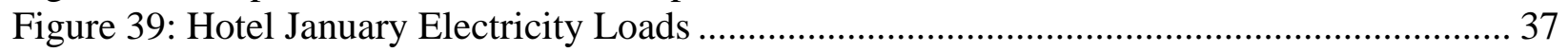

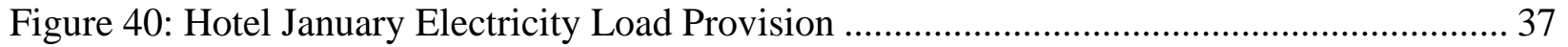

Figure 41: Hotel July Electricity Loads .......................................................................... 37

Figure 42: Hotel July Electricity Load Provision with CHP .............................................. 37

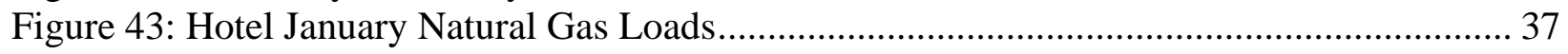

Figure 44: Hotel January Natural Gas Load Provisions with CHP ......................................... 37

Figure 45: Hotel Annual Carbon Emissions ................................................................. 38 
Figure 46: Hotel Annual Fuel Consumption................................................................................. 38

Figure 47: Retail January Weekday Electricity Loads ................................................................. 39

Figure 48: Retail January Weekday Electricity Load Provision...................................................... 39

Figure 49: Retail July Weekday Electricity Loads ......................................................................... 40

Figure 50: Retail July Weekday Electricity Load Provision with CHP........................................ 40

Figure 51: Retail January Weekday Natural Gas Loads ............................................................... 40

Figure 52: Retail January Weekday Natural Gas Load Provision with CHP ............................... 40

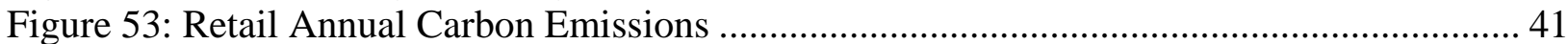

Figure 54: Retail Annual Fuel Consumption......................................................................... 41

Figure 55: Sports Facility January Electricity Loads....................................................................... 43

Figure 56: Sports Facility January Electricity Load Provision with CHP ..................................... 43

Figure 57: Sports Facility July Electricity Loads ............................................................................ 43

Figure 58: Sports Facility July Electricity Load Provision with CHP............................................ 43

Figure 59: Sports Facility January Natural Gas Loads .................................................................... 43

Figure 60: Sports Facility January Natural Gas Load Provision with CHP ................................. 43

Figure 61: Sports Facility Annual Carbon Emissions................................................................... 44

Figure 62: Sports Facility Annual Fuel Consumption ................................................................... 44

Figure 63: The Peak Load Shift Effect of Prototype Building ...................................................... 46

Figure 64 :The Effect of Prototype Building Carbon Emission Reduction..................................... 46

Figure 65: The Economic Effect of Prototype Building ...................................................... 47

Figure 66: 5,000 $\mathrm{m}^{2}$ Building Total Annual Fuel Costs .................................................... 50

Figure 67: 5,000 m² Building Total Annual Energy Costs ........................................................ 50

Figure 68 : 5,000 $\mathrm{m}^{2}$ Building Fuel Consumption................................................................ 51

Figure 69: 5,000 $\mathrm{m}^{2}$ Building Carbon Emissions .................................................................. 51

Figure 70: Total Annual Fuel Costs with Unsubsidized DER Capital Costs ................................ 53

Figure 71: Total Annual Energy Costs with Unsubsidized DER Capital Costs ............................ 53

Figure 72: Total Annual Fuel Consumption with Unsubsidized DER Capital Costs..................... 54

Figure 73: Total Annual Carbon Emissions With Unsubsidized DER Capital Costs ................... 54

Table 1 Description of Simulated Office Building ..................................................................... 7

Table 2: Distribution of Average Construction Floor Area by Building Type in Japan (\%)........ 14

Table 3: Kyushu Only Distribution of Average Floor Area by Building Type ............................. 14

Table 4: Electricity Tariffs at Several Facilities in the U.S. ..................................................... 17

Table 5: Electricity Tariffs in Several Facilities in Two Japanese Utilities ................................. 18

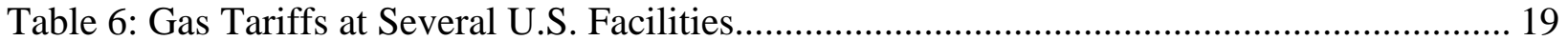

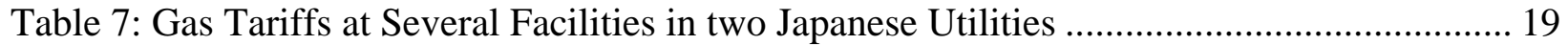

Table 8: DER Technology Information for the U.S. ................................................................... 21

Table 9: Japanese DER Technology Information (Only With Waste Heat Recovery) .................. 22

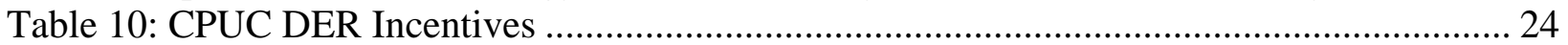

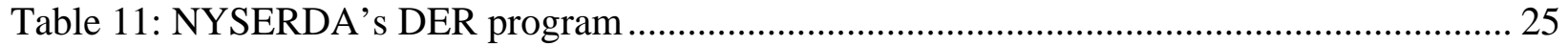

Table 12: Grants for DG in Selected Site in the U.S. ................................................................. 27

Table 13 Financial Loan for CHP Installation in Japan.............................................................. 27

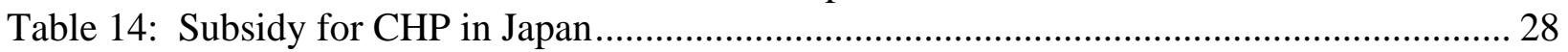

Table 15: Office Building DER-CAM Results............................................................................ 30

Table 16: Office Building Annual Carbon Emissions and Fuel Consumption............................. 32

Table 17: Office Building System Efficiency............................................................................ 32 


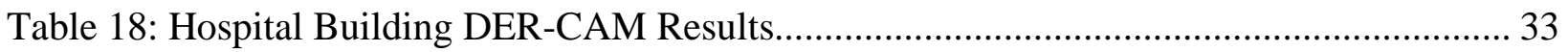

Table 19: Hospital Annual Carbon Emissions and Fuel Consumption .......................................... 35

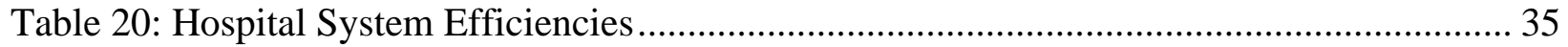

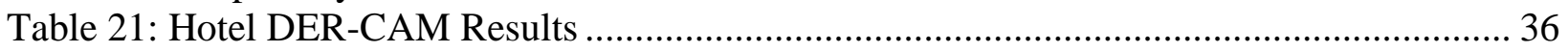

Table 22: Hotel Annual Carbon Emissions and Fuel Consumption ............................................... 38

Table 23: Hotel System Efficiencies...................................................................................... 38

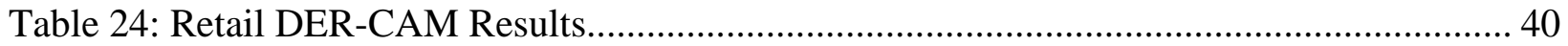

Table 25: Retail Annual Carbon Emissions and Fuel Consumption .............................................. 41

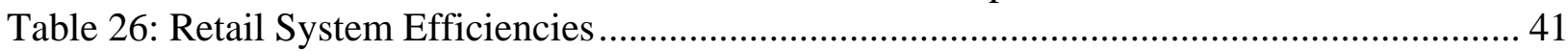

Table 27: Sports Facility DER-CAM Results.............................................................................. 42

Table 28: Sports Facility Annual Carbon Emissions and Fuel Consumption ............................... 44

Table 29: Sports Facility System Efficiencies ........................................................................ 44

Table 30: Economic Results for $5000 \mathrm{~m}^{2}$ Prototype Buildings .................................................... 49

Table 31: Fuel Consumption and Carbon Emissions for $5000 \mathrm{~m}^{2}$ Buildings ................................. 51

Table 32: The Economic Results For Unsubsidized Technology Costs........................................ 52

Table 33: Total Annual Fuel Consumption and Carbon Emission for the $10,000 \mathrm{~m}^{2}$ Buildings with Unsubsidized DER Capital Costs........................................................................ 54 



\section{Acronyms and Abbreviations}

\begin{tabular}{|c|c|}
\hline ANRE & Agency for Natural Resources and Energy \\
\hline ABSHX & DER with heat recovery for heating and absorption cooling \\
\hline $\mathrm{ACH}$ & Air Changes per Hour \\
\hline AMeDAS & Japan Automated Meteorological Data Acquisition System \\
\hline BECS & a HVAC simulation program in Japan \\
\hline CEC & California Energy Commission \\
\hline CERL & US Army Corps of Engineers Construction Engineering Research Lab \\
\hline CERTS & Consortium for Electric Reliability Technology Solutions \\
\hline CHP & Combined Heat and Power \\
\hline CPUC & California Public Utilities Commission \\
\hline DER & Distributed Energy Resources \\
\hline DER-CAM & Distributed Energy Resources Customer Adoption Model \\
\hline DOD & US Department of Defense \\
\hline DG & Distributed Generation \\
\hline Disco & distribution company \\
\hline DOE & U.S.Department of Energy \\
\hline DOE-2 & building energy simulation model developed at Berkeley Lab \\
\hline EPA & U.S.Environmental Protection Agency \\
\hline FC & fuel cell \\
\hline FERC & Federal Energy Regulatory Committee \\
\hline GT & gas turbine \\
\hline HASP & HVAC simulation program in Japan \\
\hline $\mathrm{HX}$ & DER with heat recovery for heating \\
\hline HVAC & Heating, Ventilation and Air Conditioning \\
\hline LBNL & Lawrence Berkeley National Laboratory \\
\hline LIPA & Long Island Power Authority \\
\hline METI & the Ministry of Economy, Trade and Industry, Japan \\
\hline MT & microturbine \\
\hline NEGA & Japan Engine Generator Association \\
\hline NG & gas engine \\
\hline NYPSC & New York State the Public Service Commission \\
\hline NYSERDA & New York State Energy Research and Development Authority \\
\hline O\&M & operation and maintenance \\
\hline PG\&E & Pacific Gas and Electric \\
\hline PV & photovoltaic \\
\hline PURPA & Public Utilities Regulatory Policies Act \\
\hline QFs & qualifying facilities \\
\hline SBC & system benefits charge \\
\hline SC & Shading Coefficient \\
\hline SCAQMD & South Coast Air Quality Management District \\
\hline SCE & Southern California Edison \\
\hline SDG\&E & San Diego Gas and Electric \\
\hline SDREO & San Diego Regional Energy Office \\
\hline SMASH & HVAC simulation program in Japan \\
\hline SoCalGas & Southern California Gas Company \\
\hline
\end{tabular}





\section{Acknowledgments}

The authors would like to particularly thank Joe Huang (LBNL) for his contribution to several important aspects of the modeling for this project. We would also like to thank Kazunari Shiraki (Osaka Gas Co.) and Atsushi Sakakura (Tokyo Gas Co.) for providing useful data, and Jennifer L. Edwards, Owen Bailey, and Peter Chan for their advice and editing that helped shape many of the concepts presented here.

The authors would also like to thank the Japan Kyushu Industrial Technology Center for its support of this work. Also, the prior and ongoing development of the methods and tools used in this study has been supported by the U.S. Department of Energy(DOE) and the California Energy Commission. Assistance from DOE has come from both the Distributed Energy Program and the office of Electric Transmission and Distribution.

Finally, the following Berkeley Lab researchers have contributed to DER research at Berkeley Lab in the past: Afzal Siddiqui, Michael Stadler, and Kristina Hamachi LaCommare. 



\section{Executive Summary}

The August 2003 blackout of the northeastern U.S. and CANADA caused great economic losses and inconvenience to New York City and other affected areas. The blackout was a warning to the rest of the world that the ability of conventional power systems to meet growing electricity demand is questionable. Failure of large power systems can lead to serious emergencies. Introduction of on-site generation, renewable energy such as solar and wind power and the effective utilization of exhaust heat is needed, to meet the growing energy demands of the residential and commercial sectors.

Additional benefit can be achieved by integrating these distributed technologies into distributed energy resource (DER) systems. This work demonstrates a method for choosing and designing economically optimal DER systems.

An additional purpose of this research is to establish a database of energy tariffs, DER technology cost and performance characteristics, and building energy consumption for Japan. This research builds on prior DER studies at the Ernest Orlando Lawrence Berkeley National Laboratory (LBNL) and with their associates in the Consortium for Electric Reliability Technology Solutions (CERTS) and operation, including the development of the microgrid concept, and the DER selection optimization program, the Distributed Energy Resources Customer Adoption Model (DER-CAM). DER-CAM is a tool designed to find the optimal combination of installed equipment and an idealized operating schedule to minimize a site's energy bills, given performance and cost data on available DER technologies, utility tariffs, and site electrical and thermal loads over a test period, usually an historic year. Since hourly electric and thermal energy data are rarely available, they are typically developed by building simulation for each of six end use loads used to model the building: electric-only loads, space heating, space cooling, refrigeration, water heating, and natural-gas-only loads. DER-CAM provides a global optimization, albeit idealized, that shows how the necessary useful energy loads can be provided for at minimum cost by selection and operation of on-site generation, heat recovery, cooling, and efficiency improvements.

This study examines five prototype commercial buildings and uses DER-CAM to select the economically optimal DER system for each. The five building types are office, hospital, hotel, retail, and sports facility. Each building type was considered for both 5,000 and 10,000 square meter floor sizes. The energy consumption of these building types is based on building energy simulation and published literature. Based on the optimization results, energy conservation and the emissions reduction were also evaluated. Furthermore, a comparison study between Japan and the U.S. has been conducted covering the policy, technology and the utility tariffs effects on DER systems installations.

This study begins with an examination of existing DER research. Building energy loads were then generated through simulation (DOE-2) and scaled to match available load data in the literature. Energy tariffs in Japan and the U.S. were then compared: electricity prices did not differ significantly, while commercial gas prices in Japan are much higher than in the U.S. For smaller DER systems, the installation costs in Japan are more than twice those in the U.S., but this difference becomes smaller with larger systems. In Japan, DER systems are eligible for a 
$1 / 3$ rebate of installation costs, while subsidies in the U.S. vary significantly by region and application.

For $10,000 \mathrm{~m}^{2}$ buildings, significant decreases in fuel consumption, carbon emissions, and energy costs were seen in the economically optimal results. This was most noticeable in the sports facility, followed the hospital and hotel. This research demonstrates that office buildings can benefit from CHP, in contrast to popular opinion. For hospitals and sports facilities, the use of waste heat is particularly effective for water and space heating. For the other building types, waste heat is most effectively used for both heating and cooling.

The same examination was done for the 5,000 $\mathrm{m}^{2}$ buildings. Although CHP installation capacity is smaller and the payback periods are longer, economic, fuel efficiency, and environmental benefits are still seen. While these benefits remain even when subsidies are removed, the increased installation costs lead to lower levels of installation capacity and thus benefit. 


\section{Background and Purpose}

Energy consumption in Japan has been following a consistent rising trend, except for periods during the two oil crises. From 1990 to 2000 energy consumption by the residential/commercial sector increased $26.4 \%{ }^{1}$, reflecting changes in lifestyle and desire for comfort (METI, 2004; ANRE, 2004). In Japan, a country that depends on imports for most of its primary energy supply, on-site distributed energy systems, including combined heat and power (CHP) systems and renewables, such as photovoltaics and wind turbines have grown more important and are widely expected to spread to increase the efficiency of energy consumption and to address global environmental problems. Additional benefit may be gained from distributed systems through clusters of DER and loads in the same geographic area.

The Ministry of Economy, Trade and Industry (METI) is laying down a new Long-Term Energy Supply and Demand Outlook to 2030 and an interim report was released in June 2004. The Japanese government suggests more decentralized energy systems, and the new outlook includes a distributed generation development scenario where in the share of self generation in total electricity supply exceeds 20\% in 2030 (METI, 2004).

While economics is a key to the implementation of DER, an economic optimization design tool based on technology information and current tariffs and policy has not yet been developed in Japan. This research conducts a survey of the potential for DER utilization and the installation of renewable energy in Japan. As part of this research, a database of DER technologies, Japanese energy tariffs, and prototypical building energy loads has been developed and can be used for energy conservation research.

The Distributed Energy Resources Customer Adoption Model (DER-CAM), developed by the Lawrence Berkeley National Laboratory (LBNL) of the United States is an optimization tool for DER technology selection. DER-CAM minimizes the annual energy cost of a given customer, including DER investment costs, based on input data consisting of DER technology cost and performance, electricity and natural gas tariffs, and end-use energy loads such as space heating, cooling, hot water, and electricity only. DER-CAM reports the optimal technology selection and operation schedule to meet the end-use loads of the customer.

Using DER-CAM, an investigation was conducted of economically optimal DER investments for different prototype buildings in Japan. The potential for DER in Japan and the resulting energy savings and environmental effects has been determined. Additionally, a comparison of the DER investment climate in Japan to that in the United States has been conducted.

\footnotetext{
1 Trend of energy consumption in residential and commercial sector, The Ministry of Economy, Trade and Industry (METI), http://www.enecho.meti.go.jp/english/energy/index.html and Energy and Resources Today, Agency for Natural Resources and Energy (ANRE), http://www.meti.go.jp/report/downloadfiles/g01011gj.pdf
} 



\section{Distributed Energy Resources Customer Adoption Model}

There are several DER assessment software programs available in the United States, including Washington State University Energy Program's Heatmap, and LBNL's DER-CAM. Heatmap assess the performance and economics of predetermined regional energy systems, including DER. The user specifies the DER capacity and operation schedule, pipe sizes in the CHP network, and end-use loads. Heatmap reports the total system cost, system performance statistics and environmental effects. The optimal technology for different scale buildings cannot be found automatically.

In Japan, much research on energy conservation and the environmental effects of DER has been conducted, relatively little on the economics of DER; however in many cases, DER economics will determine its potential, The assessment program CASCADE (Computer Aided Simulation for Cogeneration Assessment Design), developed by the Air Condition and Sanitation Institute of Japan has load data for five prototype buildings including: hotel, hospital, office, sports facility and factory. It can also assess total energy consumption, environmental effects, and economics of CHP. However, CASCADE has several weaknesses:

- $\quad$ It is only available as mainframe software.

- $\quad$ The data is averaged over all of Japan; i.e. it does not consider regional and climate differences.

- $\quad$ The load data is averaged, and thus does not consider load variation between days, such as between weekdays and weekend days.

- $\quad$ DER economics are not considered.

Yamaguchi Yoheh has conducted both energy saving and economic analyses for DER systems used by two office buildings and places in between the two (Yamaguchi, 2003). Okuda Hidenobu of Tokyo University has characterized the performance of the P15-07 micro gas turbine and determined economically optimized operation strategies for P15-07 CHP systems. Other DER technologies were not considered (Okuda, 2002).

Japan has several assessment tools for CHP installation but none address the economically optimal technology choice or system design. In the United States, however, there are several economic assessment tools for DER. DER-CAM is a tool for determining economically optimal DER investments for a specific site. DER-CAM determines the appropriate technology combination and operation schedule. Figure 1 shows this graphically. 


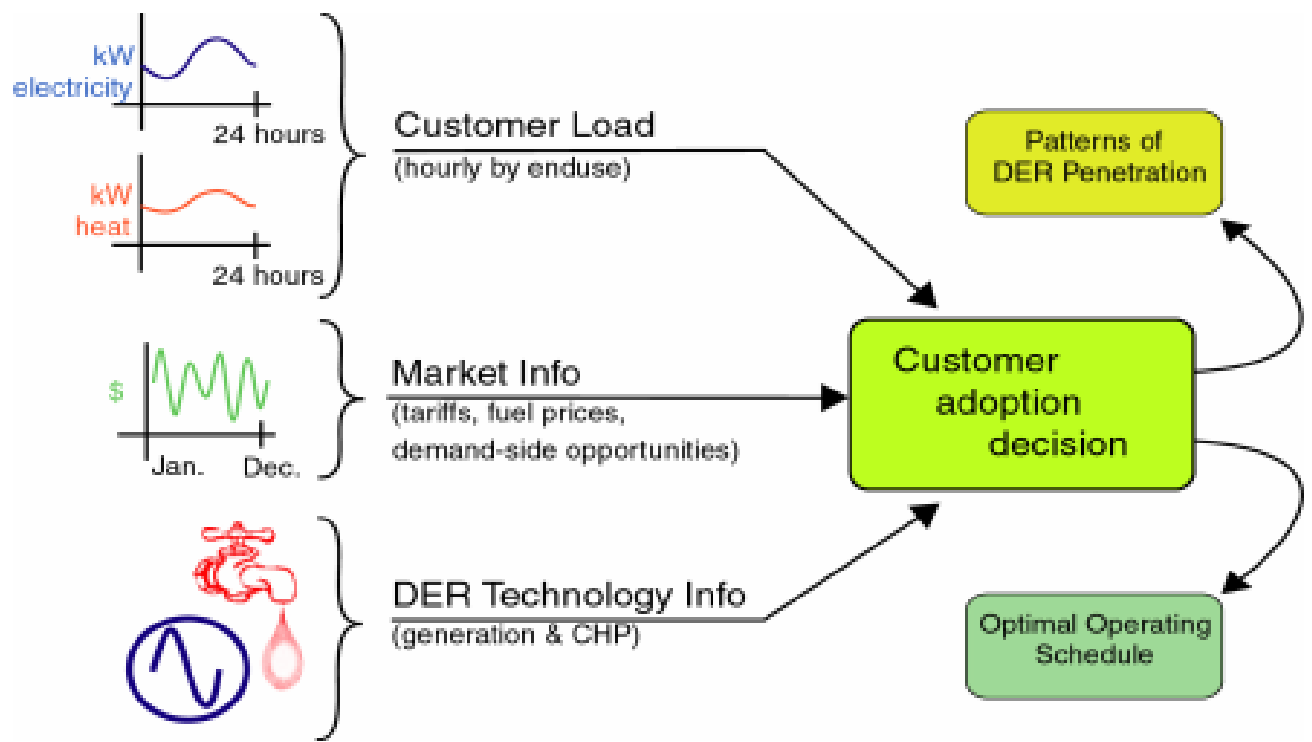

Figure 1: DER-CAM Schematic

This research uses DER-CAM to examine the potential for DER in Japan. A comparison to the climate for DER adoption in the United States is also made. 


\section{Method}

\subsection{DER-CAM}

Figure 2 is a flow chart illustrating the structure of DER-CAM. DER-CAM requires the detailed structures and rates of electricity and natural gas tariffs; hourly end-use load data for each building type; and DER technology cost and performance data. DER-CAM, in turn, determines the economically optimal DER installation and operation schedule, as well as system performance statistics. This chapter describes the development of DER-CAM input data suitable to prototype Japanese buildings.

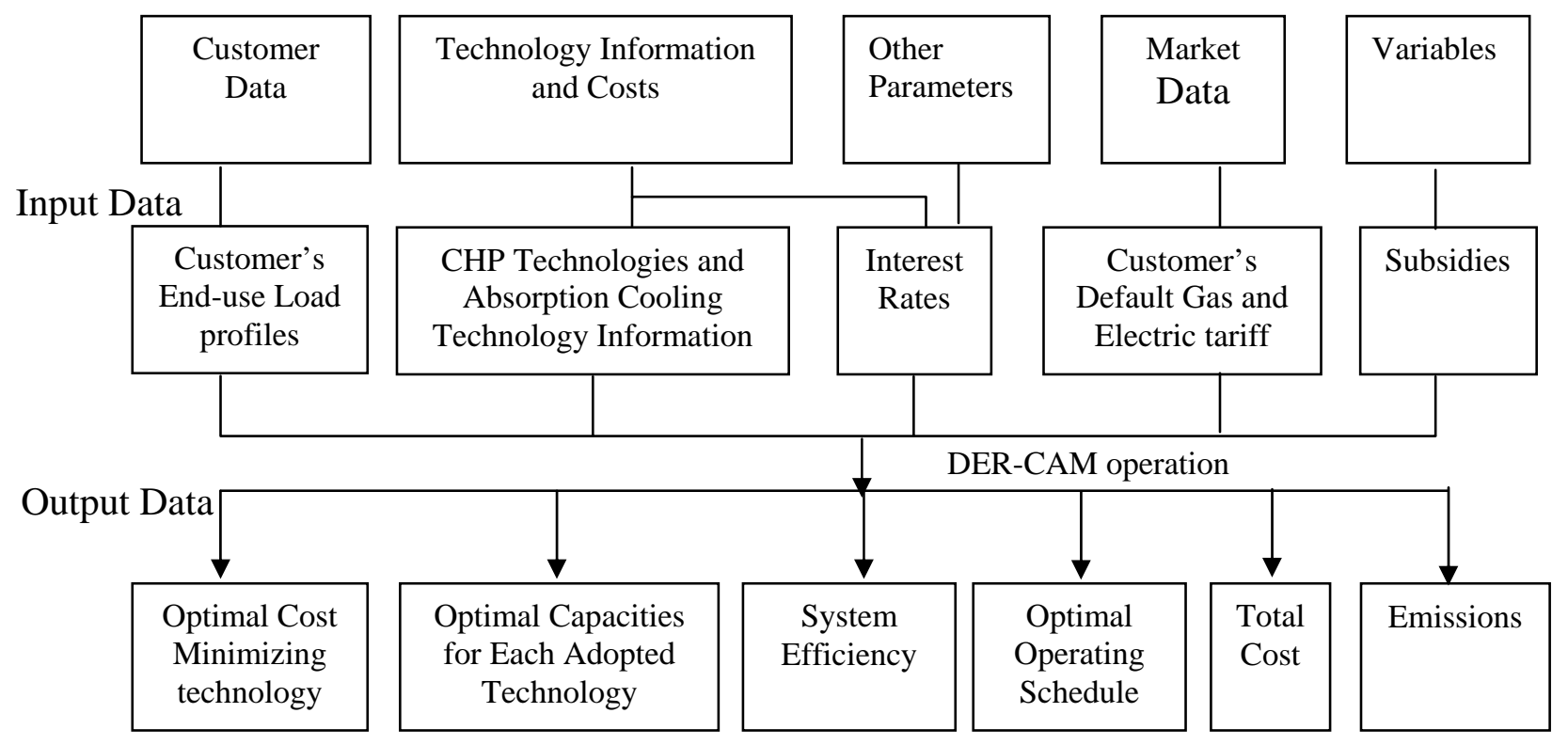

Figure 2: DER-CAM Flow Chart

Utility tariffs for commercial buildings were collected from various Japanese utilities. Financial details such as grants and taxes concerning DER installation were also obtained. DER technology data was collected from manufacturers and distributors. This data includes rated capacity, efficiency, turnkey capital cost, and operation and maintenance costs.

\subsection{Estimation of Hourly Energy Consumption}

\subsubsection{Existing Estimates}

Detailed knowledge of energy end-use loads is important for selecting an appropriate DER system. In Japan, when designing CHP systems, estimates of energy consumption intensities of various building types are typically obtained from the Natural Gas Cogeneration Plan/ Design Manual 2002 (Kashiwagi, 2002). This manual reports annual energy consumption and proportion of consumption by month and hour. Hourly loads can be estimated from this data. However this is average data for all of Japan; neither regional characteristics nor variations in load patterns by day type are considered. 
Energy consumption data of various building types in the Kyushu area was collected for the Comprehensive Research on the Utilization of Un-utilized Energy in Building and Urban Scale in Kyushu Area (Nishida, 1997). From this report, building energy consumption for buildings in Kyushu is known in great detail, although load data is not differentiated by day type, and this data is no longer current.

Several building energy simulation programs have been developed in Japan. These include:

- SMASH: developed for residential building thermal simulation by the Housing and Building Energy Conservation Organization of Japan.

- BECS: developed for calculating and simulating air conditioning equipment under Energy Conservation Law by The Society of Heating, Air-Conditioning and Sanitary Engineers of Japan

- HASP: developed for non-residential building by The Society of Heating, Air-Conditioning and Sanitary Engineers of Japan

Building energy simulation programs for other building types in Japan are not widely available.

Current, detailed load data and simulation tools for Japanese buildings of various type and in various regions is lacking. However, in the United States, the building energy simulation program, DOE-2, developed by the Department of Energy, is used in a variety of commercial packages to model various building types and determine hourly building energy loads. Heatmap incorporates DOE-2 to estimate building energy loads. DER-CAM analyses are often preceded by the use of DOE-2 to obtain end-use energy load data. In this research, a version of DOE-2 suitable to Kyushu area office buildings was developed and used to simulate office building loads. These results were checked against available energy consumption data for generalized Japanese office buildings and Kyushu office buildings.

\subsubsection{Building Loads from DOE-2 Simulation}

In Japan, An Introduction to Calculations for HVAC Dynamic Thermal Load (Matso, 1980) is widely used for building simulation. Typical office building structure, material, and HVAC operation schedule are determined based on the guidance of this book and Optimized HVAC Operation Considering Building Thermal Storage and Analysis of the Effect on Energy Consumption (Nagai, 2001)

Table 1 shows the office building condition used for the simulation and for the climate data for Tokyo from the AMeDAS database is used. 


\section{Table 1 Description of Simulated Office Building}

\begin{tabular}{|c|c|}
\hline \multicolumn{2}{|c|}{ Building description } \\
\hline \multicolumn{2}{|c|}{$\begin{array}{l}\text { Type :office } \\
\text { Floors }: 5 \text { aspect_ratio: } 0.6\left(36 \mathrm{~m}^{*} 60 \mathrm{~m}\right) \text { wall_height: } 2.6 \mathrm{~m} \text { perim_width } 6 \mathrm{~m} \\
\text { Glass ratio } 0.45 \\
\text { Area : } 10800 \mathrm{~m}^{2}\end{array}$} \\
\hline \multicolumn{2}{|c|}{ Construction and Shell Characteristics } \\
\hline \multicolumn{2}{|c|}{$\begin{array}{l}\text { Exterior Floors : preformed mineral board, air-space, } 130 \mathrm{~mm} \text { conc.,stacco,Asphalt tile } \\
\text { Interior Floors : preformed mineral board, air-space, } 130 \mathrm{~mm} \text { conc.,stacco,Asphalt tile } \\
\text { Exterior walls : tile,stacco,concrete,stacco,gyp-board thickness }=(8 \mathrm{~mm}, 25 \mathrm{~mm}, 120 \mathrm{~mm}, 20 \mathrm{~mm}, 3 \mathrm{~mm}) \\
\text { Interior walls : gyp-board,stacco,concrete,stacco,gyp-board thickness }=(3 \mathrm{~mm}, 15 \mathrm{~mm}, 100 \mathrm{~mm}, 15 \mathrm{~mm}, 3 \mathrm{~mm}) \\
\text { Roof : Asphalt tile,stacco, } 130 \mathrm{~mm} \text { conc.,air-space,preformed mineral board } \\
\text { Windows : Absorbtion Glass } 8 \mathrm{~mm} \text {, window_R } 0.92 \mathrm{U}=6.18 \mathrm{~W} / \mathrm{m}^{2} \mathrm{~K}, \mathrm{SC}=0.92\end{array}$} \\
\hline \multicolumn{2}{|l|}{ Space Conditions } \\
\hline No. of People & $\begin{array}{c}6.7 \mathrm{~m}^{2} / \text { person } \\
\left(0.15 \text { persons } / \mathrm{m}^{2}\right)\end{array}$ \\
\hline People Schedule & $\begin{array}{l}1.00 \text { working hrs, } 0.1 \text { otherwise } \\
\text { Weekend } 0.90 \text { and } 0.05\end{array}$ \\
\hline Lighting Use Intensity $\left(\mathrm{W} / \mathrm{m}^{2}\right)$ & 20 \\
\hline Lighting Schedule & 0.90 working hrs, 0.30 otherwise. Weekend 0.90 and 0.20 \\
\hline Equipment Use Intensity $\left(\mathrm{W} / \mathrm{m}^{2}\right)$ & $10\left(0.92 \mathrm{~W} / \mathrm{ft}^{2}\right)$ \\
\hline Equipment Schedule & 1.00 working hrs, 0.17 otherwise. Weekend 0.17 and 0.17 \\
\hline Infiltration & $0.3 \mathrm{ACH}$ working hours \\
\hline \multicolumn{2}{|l|}{ HVAC System and Control } \\
\hline HVAC System Type & Variable-Air Volume with Economizer \\
\hline Heating Temperature & $22^{\circ} \mathrm{C}$ \\
\hline Heating Schedule & $\begin{array}{l}\text { All Year Workdays } 8 \mathrm{am}-7 \mathrm{pm} \\
\text { Weekends } 8 \mathrm{am}-1 \mathrm{pm}\end{array}$ \\
\hline Cooling Temperature & $26^{\circ} \mathrm{C}$ \\
\hline Cooling Schedule & $\begin{array}{l}\text { All Year Workdays } 8 \text { am }-7 \text { pm } \\
\text { Weekends } 8 \text { am }-1 \text { pm }\end{array}$ \\
\hline Fan Schedule & On during working hours \\
\hline Outside air / person & $25 \mathrm{~m}^{3} / \mathrm{h}\left(14.7 \mathrm{ft}^{3} / \mathrm{min} /\right.$ person $)$ \\
\hline \multicolumn{2}{|l|}{ Service Equipment } \\
\hline Elevator Intensity & $14 \mathrm{~kW}$ \\
\hline Elevator Schedule & 1.00 working hrs, 0.17 otherwise \\
\hline Service Hot Water Intensity & $11.6 \mathrm{~L} / \mathrm{min}\left(0.00152 * 7650 \mathrm{~m}^{2}\right) / 0 *$ \\
\hline Service Hot Water Schedule & 1.00 working hrs, 0 otherwise \\
\hline
\end{tabular}

Reference: Matsuo, 1985; Nagai, 2001; and US. DOE-2 Manual, 2000

Figure 3 to Figure 6 show the July Tokyo office building simulation results of the electricity, space heating, hot water heating, and space cooling loads. Each shows peak weekday, typical weekday, and weekend loads. The cooling load is expressed as the electricity required to perform the cooling. 


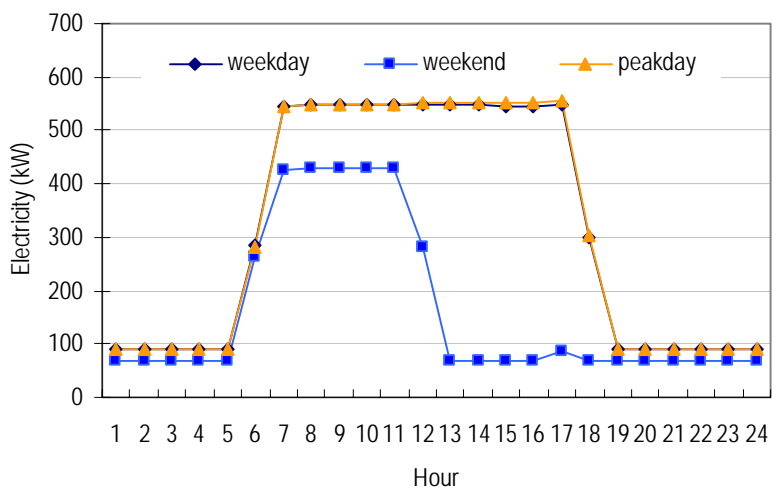

Figure 3: Office July Electricity Load from DOE-2 Simulation

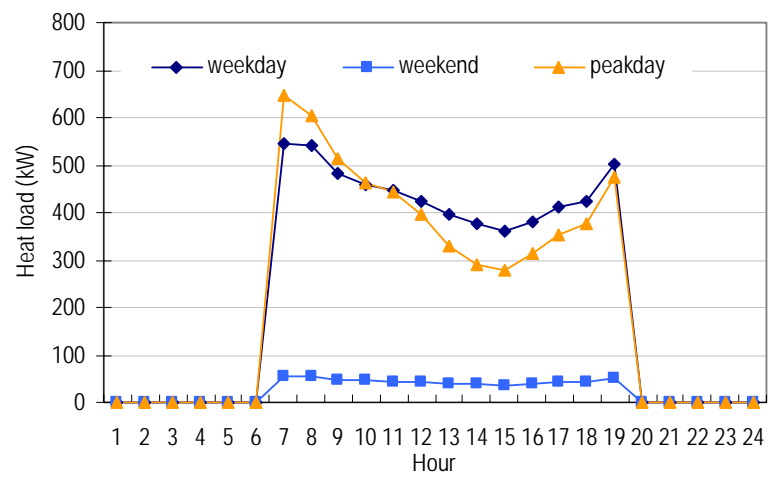

Figure 5: Office January Space Heating Load from DOE-2 Simulation

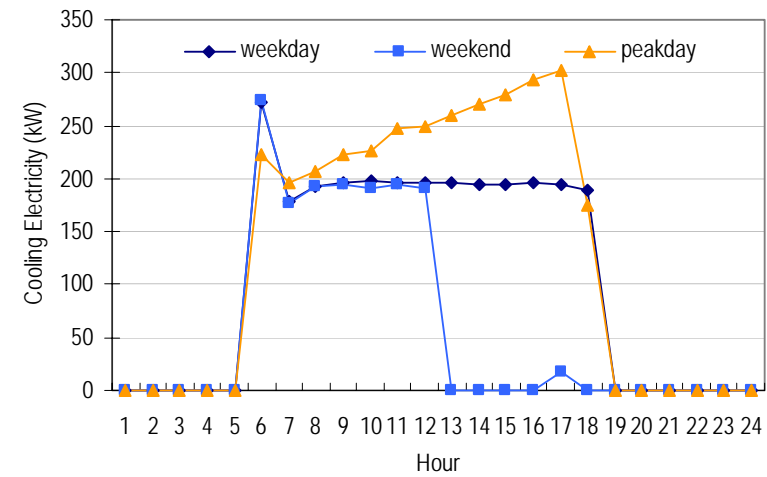

Figure 4: Office July Cooling Electricity Load from DOE-2 Simulation

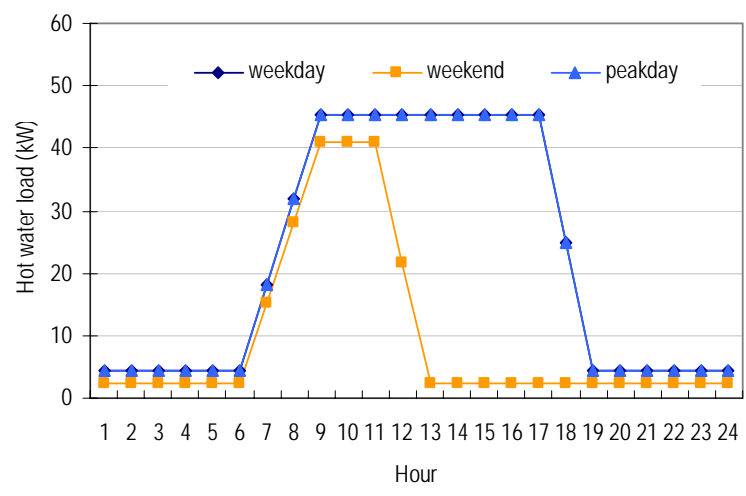

Figure 6: Office January Hot Water Load from DOE-2 Simulation

July non-cooling electricity use increases rapidly as the workday begins and is approximately $550 \mathrm{~kW}$ during the daytime. On Saturdays, there is a half-day of work with electricity consumption of approximately $430 \mathrm{~kW}$. Sundays are not represented here. July cooling electricity loads are approximately $200 \mathrm{~kW}$ for both weekdays and weekends with a peak load of approximately $300 \mathrm{~kW}$ at 5 P.M. The space heating load in January weekdays typically ranges from $360-540 \mathrm{~kW}$ and the peak load is $650 \mathrm{~kW}$. On Saturdays, the range is from $36-54 \mathrm{~kW}$. The hot water load is small, around $45 \mathrm{~kW}$.

\subsubsection{Comparison of Three Load Data Sources}

Figure 7 through Figure 9 show hourly electricity-only load data for a 10,000 $\mathrm{m}^{2}$ office building in Kyushu area. Figure 7 is the result of a DOE-2 simulation using Fukuoka climate, Figure 8 shows an estimate from the Kyushu Area Energy Consumption Intensities (Nishida, 1997), and Figure 9 load data derived from energy consumption data in Natural Gas Cogeneration Plan/ Design Manual 2002 (Kashiwagi, 2002). Below each are represented as Kyushu and Japan intensities respectively. 


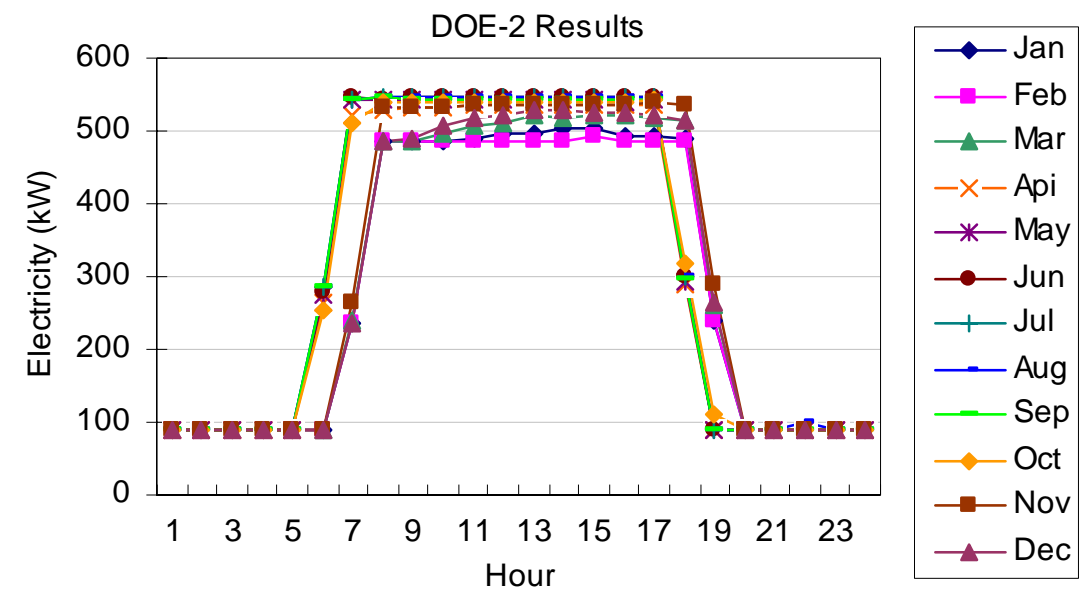

Figure 7: Electricity Only Loads from DOE-2 Simulation

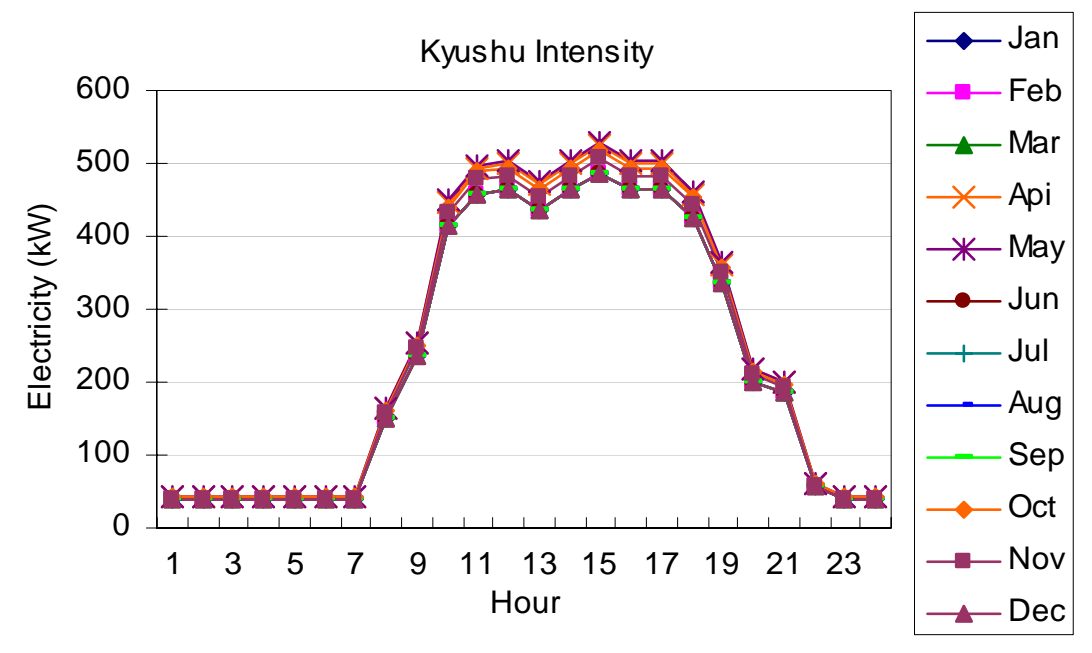

Figure 8: Electricity Only Loads from Kyushu Intensity (1997)

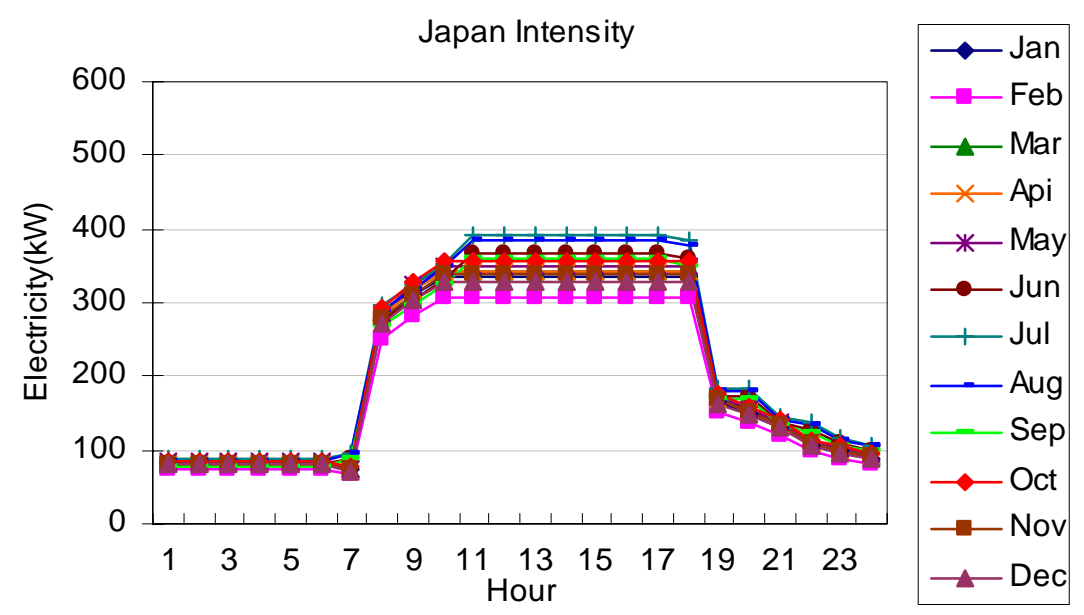

Figure 9: Electricity Only Loads from Japan Intensity (2002) 
Non-cooling electricity loads from DOE-2 and Kyushu intensity (1997) have a flat daytime profile with a daytime load of approximately $500 \mathrm{~kW}$ year round. Day-time electricity loads from Japan intensity (2002) are also flat, but are approximately $150 \mathrm{~kW}$ smaller.

The cooling electricity loads are shown in Figure 10 through Figure 12. From the data of Kyushu intensity (1997), loads are $150 \mathrm{~kW}$ during the summer and $30 \mathrm{~kW}$ during the fall and spring. The data from Japan intensity (2002) is higher with this: $150-200 \mathrm{~kW}$ during the summer and 50 - $70 \mathrm{~kW}$ during fall and spring. From DOE-2, summer loads are approximately $200 \mathrm{~kW}$. Both the shape and magnitudes of the load profiles vary significantly among the three sources.

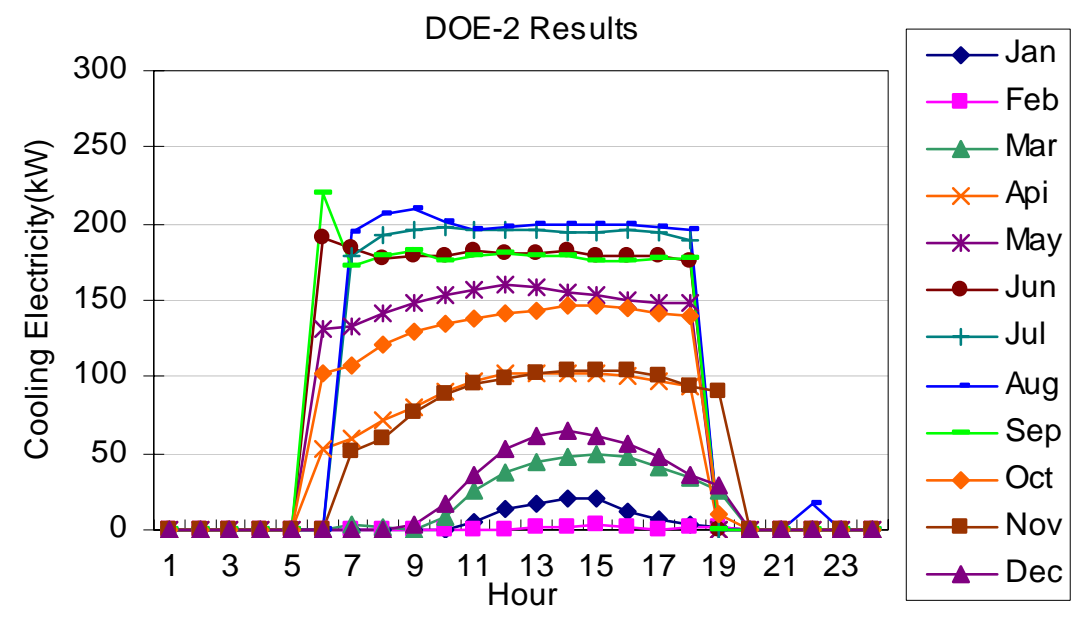

Figure 10: Cooling Electricity Load from DOE-2

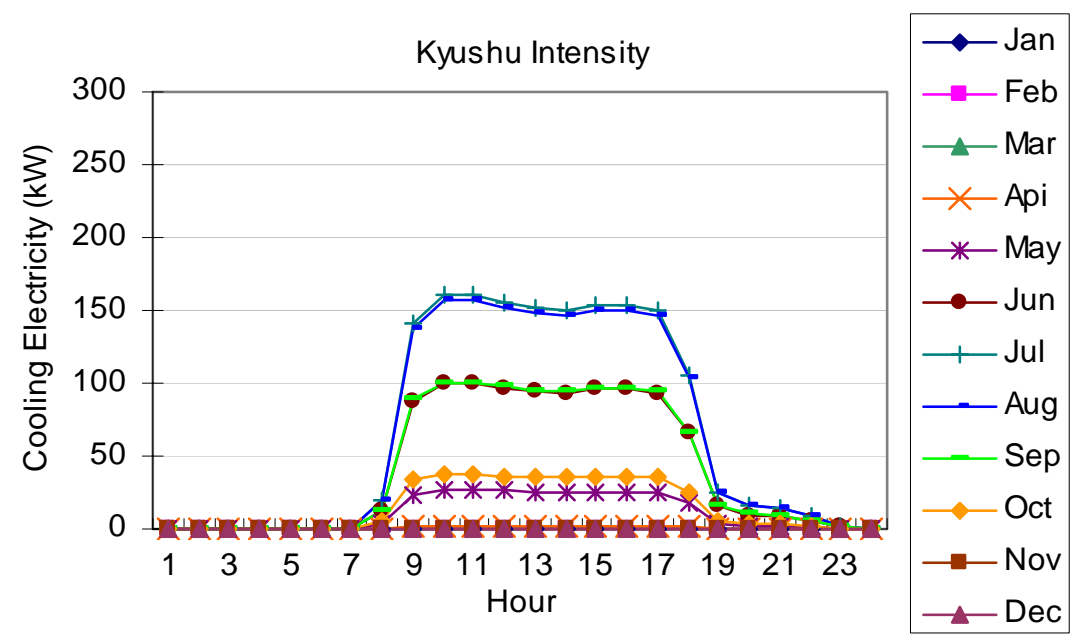

Figure 11: Cooling Electricity Load from Kyushu Intensity (1997) 


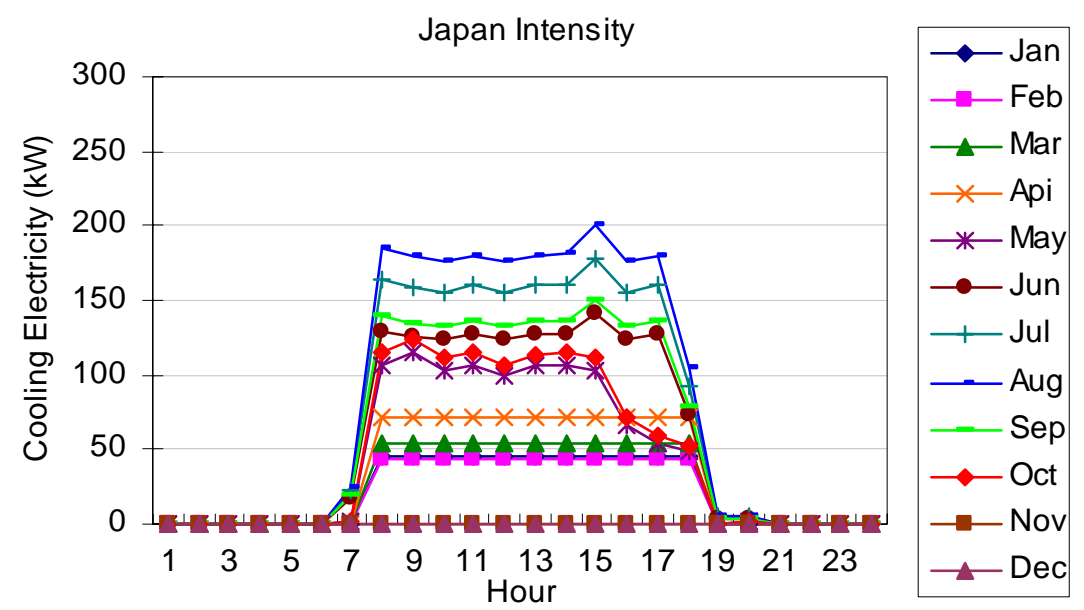

Figure 12: Cooling Electricity Load from Japan Intensity (2002)

The space heating and hot water loads are shown in Figure 13 through Figure 18. For space heating, the Kyushu intensity (1997) and Japan intensity (2002) show similar patterns while the DOE-2 data is higher. The loads are approximately 500-600 kW with a peak load of $974 \mathrm{~kW}$. The Kyushu intensity (1997) has a peak load of $700 \mathrm{~kW}$ at 8 A.M. The DOE-2 data has loads varying from 400 to $600 \mathrm{~kW}$ during the workday.

For hot water loads, DOE-2 data shows a flat profile during the day which is 20 to $30 \mathrm{~kW}$ higher than the other two data sources. The Japan intensity (2002) data has the lowest values, with a peak load at 12 P.M., but the Kyushu intensity (1997) has a peak load at the beginning of the workday.

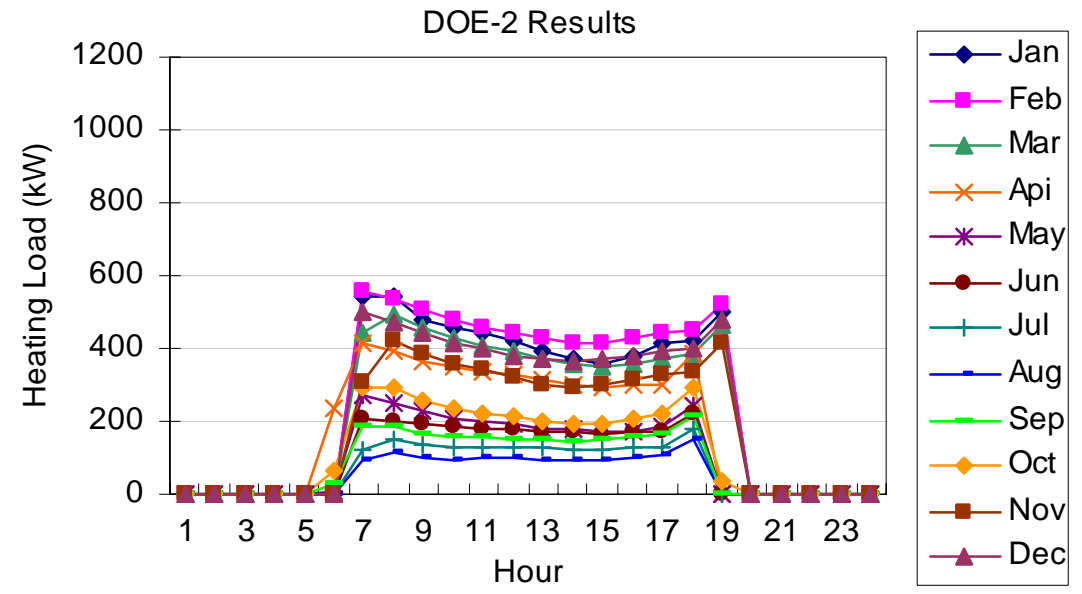

Figure 13: Heating Load from DOE-2 


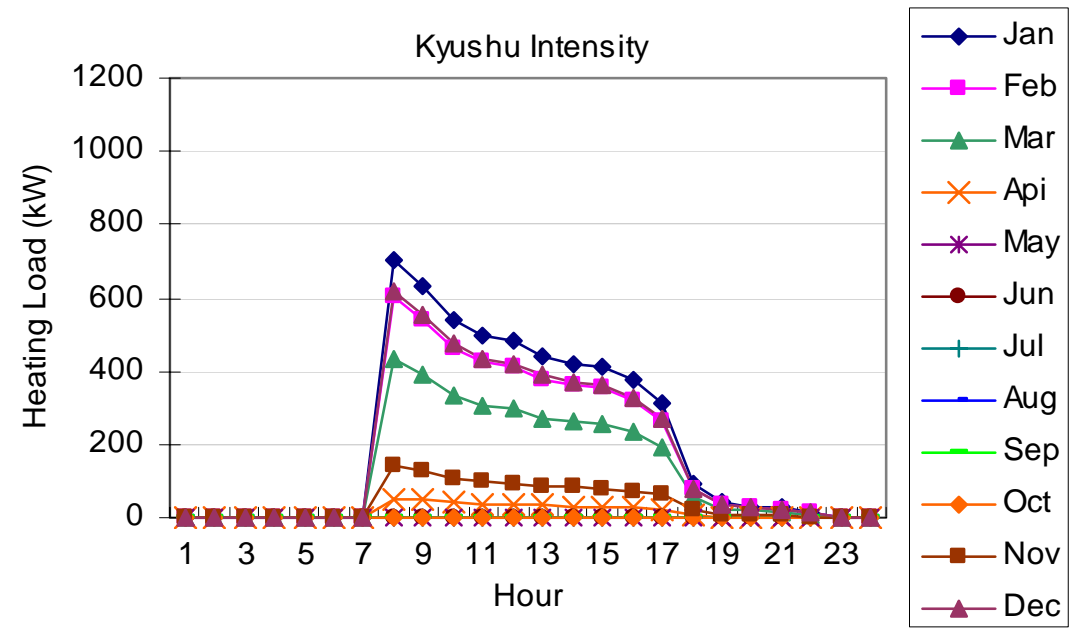

Figure 14: Heating load from Kyushu Intensity (1997)

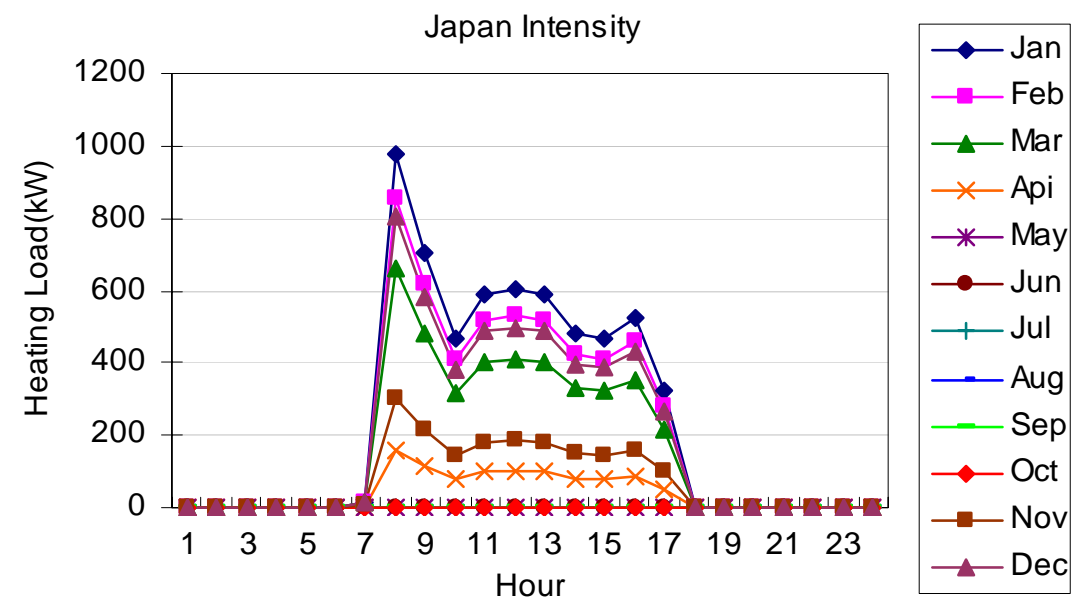

Figure 15: Heating Load from Japan Intensity (2002)

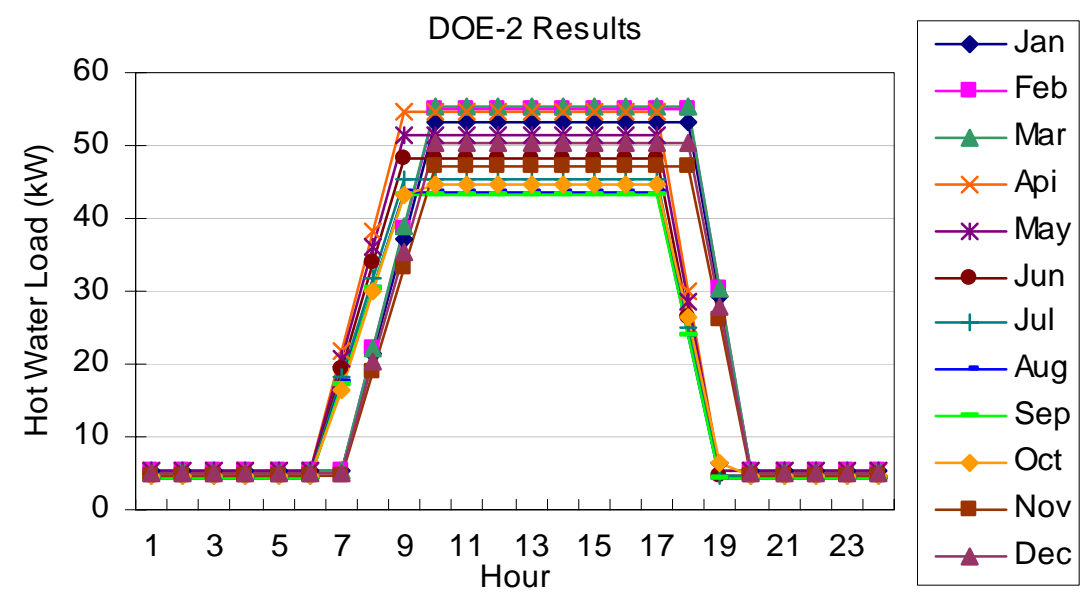

Figure 16: Hot Water Load from DOE-2 


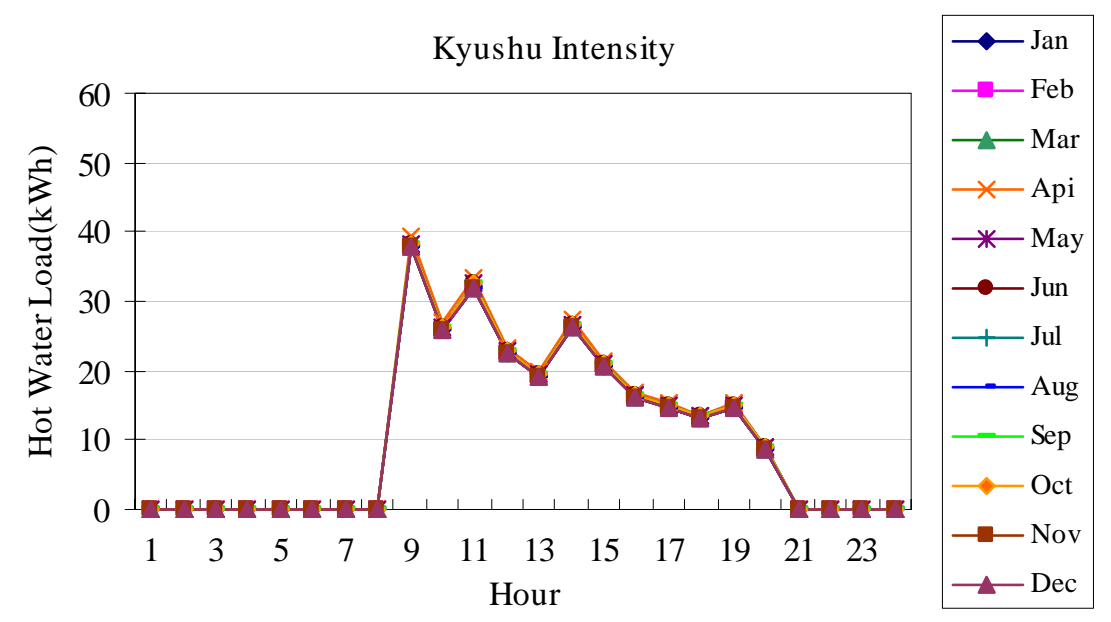

Figure 17: Hot Water Load from Kyushu Intensity (1997)

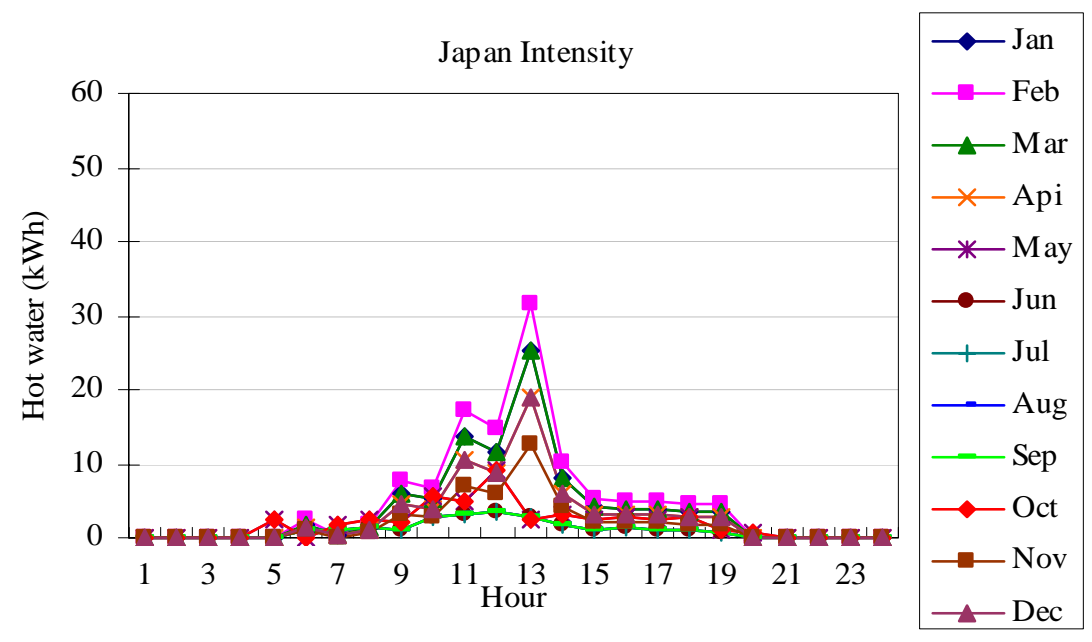

Figure 18: Hot Water Load from Japan Intensity (2002)

Discrepancies in the data sources shown above suggest that additional information is needed to accurately determine the energy load profiles of actual buildings. For this research, the most conservative (smallest) estimates of loads were used for all enduses so that economic savings would not be overstated. DOE-2 was used to model office buildings only because building data required for DOE-2 models was not available for the other building types considered here. Data from Japan intensity (2002) is commonly used for DER planning and design. It is derived from actual buildings throughout Japan and although not differentiated by climate it was used for this research. 


\subsubsection{Selection of Building Size}

The five prototype buildings considered in this study are:

- office building

- hospital

- hotel

- retail

- sports facility

Table 2 and Figure 19 show the average distribution of construction floor area distribution for various building types in Japan. This data is from The Ministry of Construction's (present Ministry of Land, Infrastructure and Transport) "Construction Data and Statistics Annual Report”. Most office buildings are below 5,000 $\mathrm{m}^{2}$ but there are many above $10,000 \mathrm{~m}^{2}$ and under 2,000 $\mathrm{m}^{2}$. The results of a survey of Kyushu area buildings is shown in Table 3 and Figure 20 (Nishida,1997). Most sports facilities in this survey are between 3,000 and 5,000 $\mathrm{m}^{2}$. Most hotels are larger than $10,000 \mathrm{~m}^{2}$, and most hospitals are smaller than $7,500 \mathrm{~m}^{2}$, but there are also many buildings over $20,000 \mathrm{~m}^{2}$. There are similar numbers of commercial buildings from 5,000 to $10,000 \mathrm{~m}^{2}$ and over $10,000 \mathrm{~m}^{2}$. Research has shown that buildings are smaller in Kyushu than in other areas. The appropriate building scale to consider for DER is discussed below.

Table 2: Distribution of Average Construction Floor Area by Building Type in Japan (\%)

\begin{tabular}{lcccc}
\hline & $<2,000 \mathrm{~m}^{2}$ & $2,000-4,999 \mathrm{~m}^{2}$ & $5,000-9,999 \mathrm{~m}^{2}$ & $>10,000 \mathrm{~m}^{2}$ \\
\hline Office & 55.4 & 14.9 & 11.1 & 18.6 \\
Retail & 39.3 & 15.4 & 13.6 & 31.7 \\
Restaurant & 39.3 & 24.1 & 18.9 & 17.7 \\
Hotel & 39.3 & 15.4 & 13.6 & 31.7 \\
Hospital & 23.7 & 26.8 & 26.7 & 22.8 \\
school & 33.5 & 27.5 & 30.3 & 8.7 \\
others & 39.3 & 24.1 & 18.9 & 17.7 \\
\hline
\end{tabular}

Table 3: Kyushu Only Distribution of Average Floor Area by Building Type

\begin{tabular}{lccc}
\hline & Number of Buildings & Average Floor Area $\left(\mathrm{m}^{2}\right)$ & Average Stories \\
\hline Office & 367 & 9,039 & 8.5 \\
Commercial Building & 133 & 11,658 & 5.4 \\
Hospital & 68 & 8,737 & 5.2 \\
Hotel & 50 & 11,970 & 11 \\
Educational Facility & 68 & 6,175 & 5.1 \\
Cultural Facility & 45 & 6,680 & 5.1 \\
Sports Facility & 34 & 5,096 & 2.9 \\
Average & & 8,853 & 6.9 \\
\hline
\end{tabular}




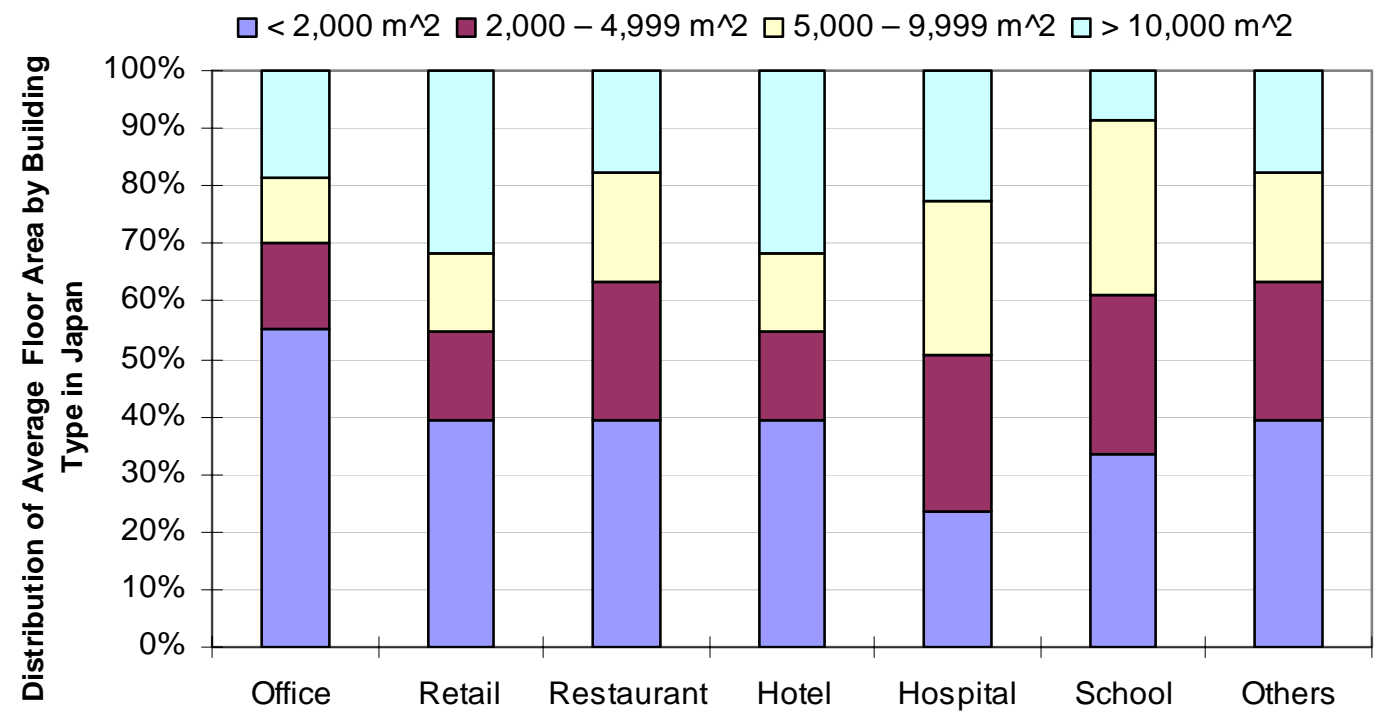

Figure 19: Distribution of Average Construction Floor Area by Building Type

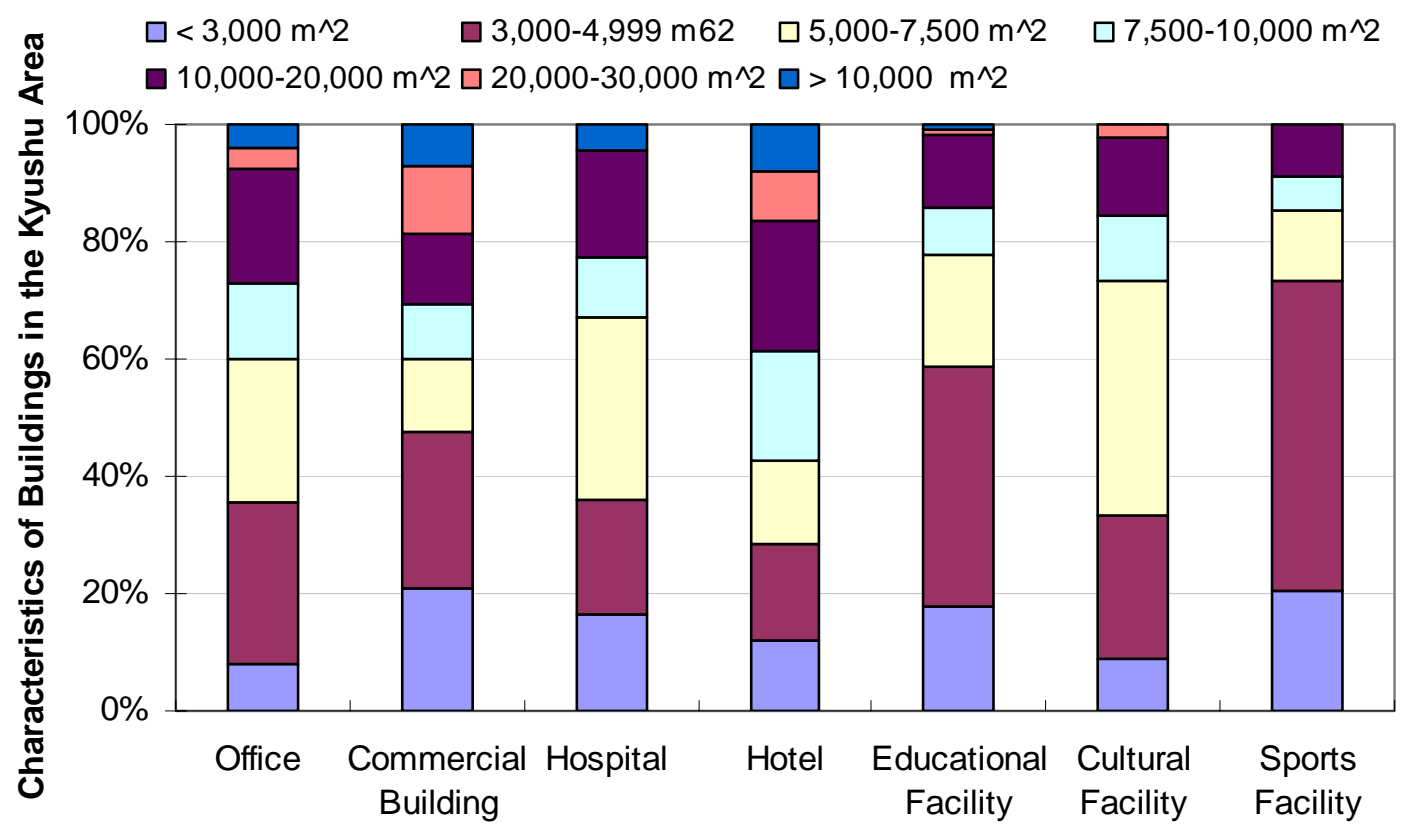

Figure 20: Characteristics of Buildings in the Kyushu Area

\subsection{Comparison of Utility Tariffs in Japan and the U.S.}

Utility electricity and gas tariffs are key factors determining the economic benefit of the CHP installation. In Japan, major electricity companies include Tokyo Electric Power Co,.INC, Kansai Electric Power Co,.INC and Kyushu Electric Power Co,.INC. Figure 21shows a map of electricity company service territories in Japan. Tokyo Gas, Osaka Gas, and Saibu Gas are the 
major natural gas companies. Unlike the U.S., tariff structures and rates do not vary much from utility to utility.

Electric Map

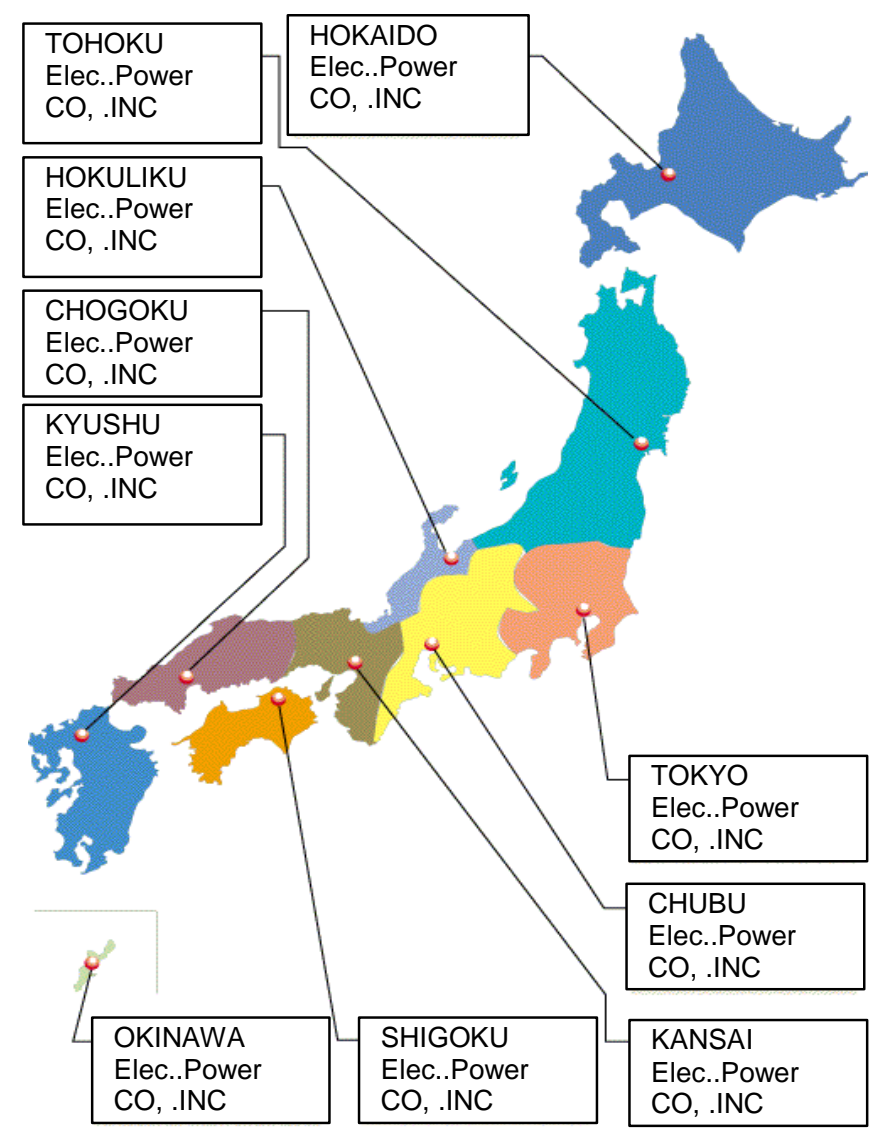

Figure 21: Japanese Electric Utility Service Territories

A comparison of Japan and U.S. energy rates was completed using Tokyo Electric Power Co,.INC and Kyushu Electric Power Co,.INC for Japanese electricity, and Tokyo Gas and Saibu Gas for Japanese natural gas. Bailey, 2003 reports a range of U.S. rates. Table 4 shows the electricity tariffs of several facilities in the U.S., and Table 8 shows equivalent tariffs for Tokyo Electricity and Kyushu Electricity. The exchange rate used was that of October, 2003: US\$1 = $120 ¥$. 
The Potential for Distributed Generation in Japanese Prototype Buildings: English Version

Table 4: Electricity Tariffs at Several Facilities in the U.S.

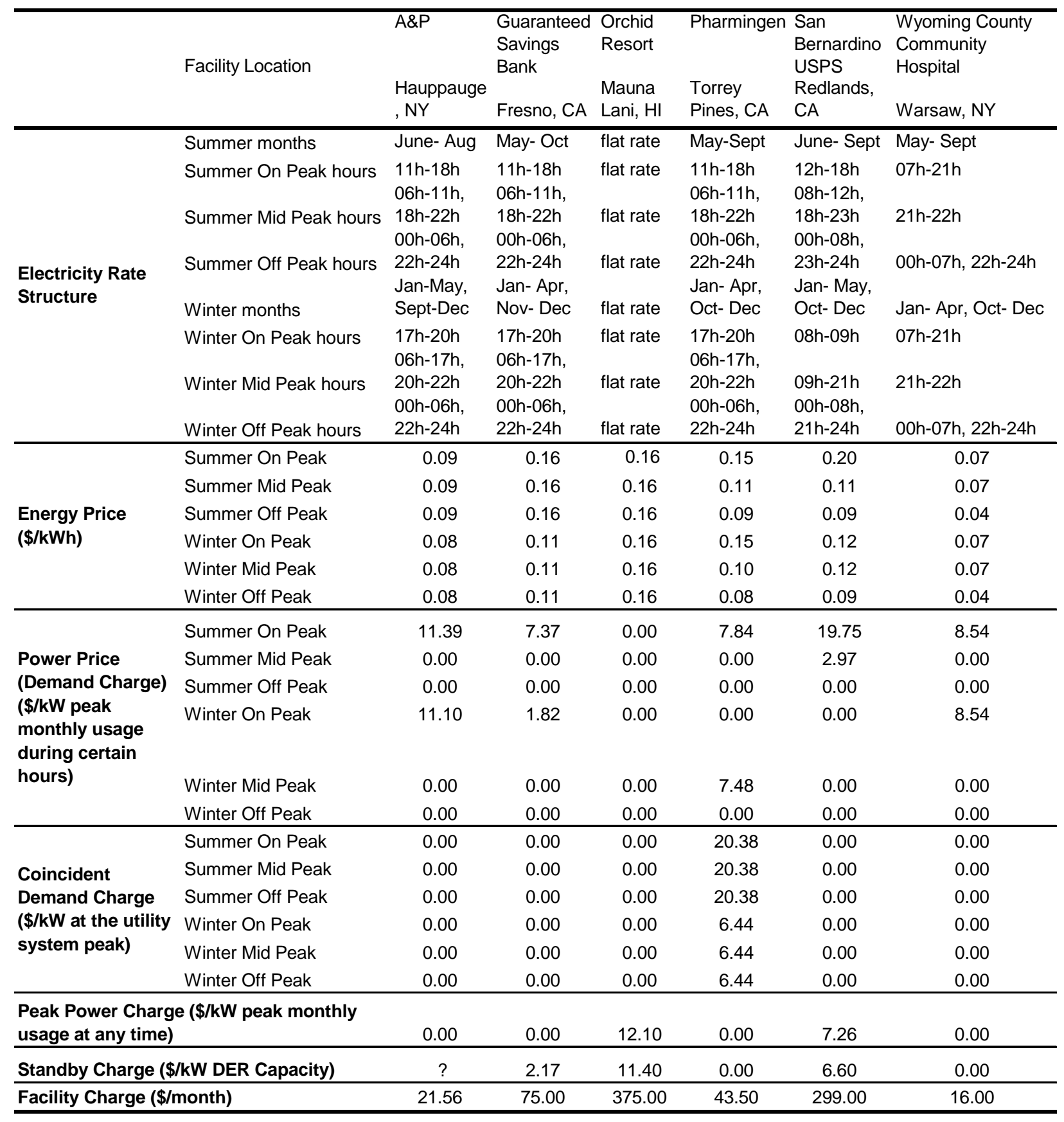


Table 5: Electricity Tariffs in Several Facilities in Two Japanese Utilities

\begin{tabular}{|c|c|c|c|c|c|c|c|c|c|}
\hline & & $\begin{array}{l}\text { Commercial } \\
\text { Electricity* }\end{array}$ & $\begin{array}{r}\text { Oomercial Tar } \\
\text { Elec.C } \\
\text { Commercial } \\
\text { Electricity II }\end{array}$ & $\begin{array}{l}\text { riff of KYUSH } \\
\text { Co,.INC } \\
\text { Commercial } \\
\text { Electricity } \\
\text { with Peak } \\
\text { Hour }\end{array}$ & $\begin{array}{l}\text { HU } \\
\text { Commercial } \\
\text { Electricity } \\
\text { with Peak } \\
\text { Hour II }\end{array}$ & $\begin{array}{l}\text { Commercial } \\
\text { Electricity }\end{array}$ & $\begin{array}{r}\text { Comercial Ta } \\
\text { Elec.C } \\
\text { Commercial } \\
\text { Electricity II }\end{array}$ & $\begin{array}{l}\text { ariff of TOKYC } \\
\text { Co,.INC } \\
\text { Commercial } \\
\text { Electricity } \\
\text { with Peak } \\
\text { Hour }\end{array}$ & $\begin{array}{l}\text { O } \\
\text { Commercial } \\
\text { Electricity } \\
\text { with Peak } \\
\text { Hour II }\end{array}$ \\
\hline $\begin{array}{l}\text { Electricity Rates } \\
\text { Structure }\end{array}$ & $\begin{array}{l}\text { Summer months } \\
\text { Summer On Peak hours } \\
\text { Summer Mid Peak hours } \\
\text { Summer Off Peak hours } \\
\text { Winter months } \\
\text { Winter On Peak hours } \\
\text { Winter Mid Peak hours } \\
\text { Winter Off Peak hours } \\
\end{array}$ & \multicolumn{4}{|c|}{$\begin{array}{l}\text { July- September } \\
13 \mathrm{~h}-16 \mathrm{~h} \\
8 \mathrm{~h}-13 \mathrm{~h}, 16 \mathrm{~h}-22 \mathrm{~h} \\
00 \mathrm{~h}-08 \mathrm{~h}, 22 \mathrm{~h}-24 \mathrm{~h} \\
\text { January-June, September-December } \\
13 \mathrm{~h}-16 \mathrm{~h} \\
8 \mathrm{~h}-13 \mathrm{~h}, 16 \mathrm{~h}-22 \mathrm{~h} \\
00 \mathrm{~h}-08 \mathrm{~h}, 22 \mathrm{~h}-24 \mathrm{~h} \\
\end{array}$} & \multicolumn{4}{|c|}{$\begin{array}{l}\text { July- September } \\
13 \mathrm{~h}-16 \mathrm{~h} \\
8 \mathrm{~h}-13 \mathrm{~h}, 16 \mathrm{~h}-22 \mathrm{~h} \\
00 \mathrm{~h}-08 \mathrm{~h}, 22 \mathrm{~h}-24 \mathrm{~h} \\
\text { January-June, September-December } \\
13 \mathrm{~h}-16 \mathrm{~h} \\
8 \mathrm{~h}-13 \mathrm{~h}, 16 \mathrm{~h}-22 \mathrm{~h} \\
00 \mathrm{~h}-08 \mathrm{~h}, 22 \mathrm{~h}-24 \mathrm{~h} \\
\end{array}$} \\
\hline \multirow{6}{*}{$\begin{array}{l}\text { Energy Price } \\
\text { (\$/kWh) }\end{array}$} & Summer On Peak & 0.12 & 0.08 & 0.18 & 0.11 & 0.10 & 0.09 & 0.13 & 0.12 \\
\hline & Summer Mid Peak & 0.12 & 0.08 & 0.15 & 0.09 & 0.10 & 0.09 & 0.12 & 0.11 \\
\hline & Summer Off Peak & 0.12 & 0.08 & 0.04 & 0.04 & 0.10 & 0.09 & 0.05 & 0.05 \\
\hline & Winter On Peak & 0.11 & 0.07 & 0.18 & 0.11 & 0.09 & 0.08 & 0.13 & 0.12 \\
\hline & Winter Mid Peak & 0.11 & 0.07 & 0.14 & 0.08 & 0.09 & 0.08 & 0.11 & 0.93 \\
\hline & Winter Off Peak & 0.11 & 0.07 & 0.04 & 0.04 & 0.09 & 0.08 & 0.05 & 0.05 \\
\hline \multicolumn{10}{|l|}{$\begin{array}{l}\text { Power Price } \\
\text { (Demand Charge) }\end{array}$} \\
\hline hours) & Winter & 10.00 & 18.58 & 10.00 & 18.58 & 13.00 & 15.50 & 13.00 & 15.50 \\
\hline
\end{tabular}

Electricity rates vary by season and by time of day, but in both countries, there are three main components to each monthly bill.

- $\quad$ Fixed monthly charge (\$)

- Demand charge: proportional to maximum power consumption during the month $(\$ / \mathrm{kW})$

- Energy charge: proportional to the amount of energy consumed ( $\$ / \mathrm{kWh})$

Table 9 shows the gas tariffs of six different U.S. facilities. Table 7 shows CHP rates and seasonal rates for Saibu Gas and Tokyo Gas. For a general facility without CHP installation, if monthly consumption for any month is less than 75\% of the maximum consumption for any month, the General Rate is applied. Otherwise, the less expensive seasonal rate will be applied. Accurately comparing the cost of natural gas in Japan and the United States is difficult because of the complex Japan gas tariff structure. However, costs in Japan are roughly two to three times higher than in the U.S. Even the cogeneration rate, which is much lower than other rates, is still higher than rates in the United States. 
The Potential for Distributed Generation in Japanese Prototype Buildings: English Version

Table 6: Gas Tariffs at Several U.S. Facilities

\begin{tabular}{|c|c|c|c|c|c|c|}
\hline & & $\begin{array}{l}\text { Guaranteed } \\
\text { Savings Bank }\end{array}$ & Orchid Resort* & Pharmingen & $\begin{array}{l}\text { San Bernardino } \\
\text { USPS }\end{array}$ & $\begin{array}{l}\text { Wyoming County } \\
\text { Community Hospital }\end{array}$ \\
\hline & Hauppauge, NY & Fresno, CA & Mauna Lani, $\mathrm{HI}$ & Torrey Pines, CA & Redlands, CA & Warsaw, NY \\
\hline month & cost $(\$ / k J)$ & cost $(\$ / k J)$ & cost $(\$ / \mathrm{kJ})$ & cost $(\$ / k J)$ & cost $(\$ / k J)$ & cost $(\$ / k J)$ \\
\hline January & 8.29E-06 & 8.76E-06 & 9.94E-06 & 5.26E-06 & $6.27 E-06$ & 4.19E-06 \\
\hline February & 7.85E-06 & 8.33E-06 & 9.94E-06 & 4.99E-06 & 5.30E-06 & 4.19E-06 \\
\hline March & 8.17E-06 & 8.07E-06 & 9.94E-06 & 5.14E-06 & $5.28 \mathrm{E}-06$ & 4.19E-06 \\
\hline April & 8.40E-06 & 7.10E-06 & 9.94E-06 & 4.40E-06 & 5.40E-06 & 4.19E-06 \\
\hline May & 8.50E-06 & $6.85 \mathrm{E}-06$ & 9.94E-06 & 4.94E-06 & 6.09E-06 & 4.19E-06 \\
\hline June & 8.71E-06 & 5.84E-06 & 9.94E-06 & 4.71E-06 & 5.64E-06 & 4.19E-06 \\
\hline July & $8.46 \mathrm{E}-06$ & 6.47E-06 & 9.94E-06 & 4.82E-06 & 4.19E-06 & 4.19E-06 \\
\hline August & 7.80E-06 & $5.75 E-06$ & 9.94E-06 & $5.28 \mathrm{E}-06$ & 3.91E-06 & 4.19E-06 \\
\hline September & 7.27E-06 & 5.55E-06 & 9.94E-06 & 5.39E-06 & 4.19E-06 & 4.19E-06 \\
\hline October & 6.69E-06 & 6.10E-06 & 9.94E-06 & 5.31E-06 & 3.73E-06 & 4.19E-06 \\
\hline November & 8.14E-06 & $6.77 \mathrm{E}-06$ & 9.94E-06 & 5.60E-06 & 4.06E-06 & 4.19E-06 \\
\hline December & 7.81E-06 & $7.56 \mathrm{E}-06$ & 9.94E-06 & 5.99E-06 & 5.94E-06 & 4.19E-06 \\
\hline
\end{tabular}

Table 7: Gas Tariffs at Several Facilities in two Japanese Utilities

\begin{tabular}{|c|c|c|c|c|c|c|c|c|c|c|c|c|c|}
\hline \multirow[b]{3}{*}{ month } & \multicolumn{4}{|c|}{ Comercial Gas Tariff of SAIBU Gas CO. } & \multicolumn{9}{|c|}{ Comercial Gas Tariff of SAIBU Gas CO. } \\
\hline & & CHP Systen & n Program & & & CHP Syste & n Program & & Commerci & al Seasona & A Program & Gen & eral $F$ \\
\hline & $\begin{array}{c}\text { Flow Rate } \\
(\$ / \mathrm{kJ})\end{array}$ & $\begin{array}{c}\text { Maxmum } \\
\text { Demand } \\
\text { Season } \\
\text { Charge } \\
(\$ / \mathrm{kJ})\end{array}$ & $\begin{array}{c}\text { Energy } \\
\text { Charge } \\
(\$ / \mathrm{kJ})\end{array}$ & $\begin{array}{c}\text { Demand } \\
\text { Charge } \\
(\$ / \text { mon })\end{array}$ & $\begin{array}{l}\text { Flow } \\
\text { Rate } \\
(\$ / k J)\end{array}$ & $\begin{array}{c}\text { Maxmum } \\
\text { Demand } \\
\text { Season } \\
\text { Charge } \\
(\$ / \mathrm{kJ})\end{array}$ & $\begin{array}{c}\text { Energy } \\
\text { Charge } \\
(\$ / \mathrm{kJ})\end{array}$ & $\begin{array}{l}\text { Demand } \\
\text { Charge } \\
(\$ / \text { mon })\end{array}$ & $\begin{array}{l}\text { Flow } \\
\text { Rate } \\
(\$ / k J)\end{array}$ & $\begin{array}{c}\text { Energy } \\
\text { Charge } \\
(\$ / \mathrm{kJ})\end{array}$ & $\begin{array}{l}\text { Demand } \\
\text { Charge } \\
(\$ / \text { mon })\end{array}$ & $\begin{array}{c}\text { Energy } \\
\text { Charge } \\
(\$ / \mathrm{kJ})\end{array}$ & $\begin{array}{l}\text { Demand } \\
\text { Charge } \\
(\$ / \text { mon })\end{array}$ \\
\hline January & $1.72 \mathrm{E}-04$ & $2.28 \mathrm{E}-07$ & $9.62 \mathrm{E}-06$ & $2.50 E+02$ & 2.15E-04 & $2.28 \mathrm{E}-07$ & 8.50E-06 & $1.79 \mathrm{E}+02$ & 2.15E-04 & $1.38 \mathrm{E}-05$ & $1.42 \mathrm{E}+02$ & $1.93 \mathrm{E}-05$ & $8.01 E+01$ \\
\hline February & $1.72 \mathrm{E}-04$ & $2.28 \mathrm{E}-07$ & $9.62 \mathrm{E}-06$ & $2.50 E+02$ & 2.15E-04 & $2.28 \mathrm{E}-07$ & $8.50 \mathrm{E}-06$ & $1.79 E+02$ & 2.15E-04 & $1.38 \mathrm{E}-05$ & $1.42 \mathrm{E}+02$ & $1.93 \mathrm{E}-05$ & $8.01 E+01$ \\
\hline March & $1.72 \mathrm{E}-04$ & $2.28 \mathrm{E}-07$ & $9.62 \mathrm{E}-06$ & $2.50 \mathrm{E}+02$ & $2.15 \mathrm{E}-04$ & $2.28 \mathrm{E}-07$ & $8.50 \mathrm{E}-06$ & $1.79 \mathrm{E}+02$ & 2.15E-04 & $1.38 \mathrm{E}-05$ & $1.42 \mathrm{E}+02$ & 1.93E-05 & $8.01 \mathrm{E}+01$ \\
\hline April & $1.72 \mathrm{E}-04$ & $2.28 \mathrm{E}-07$ & $9.62 \mathrm{E}-06$ & $2.50 \mathrm{E}+02$ & 2.15E-04 & $2.28 \mathrm{E}-07$ & $8.58 \mathrm{E}-06$ & $1.79 \mathrm{E}+02$ & 2.15E-04 & 1.17E-05 & $1.42 \mathrm{E}+02$ & 1.99E-05 & $8.01 E+01$ \\
\hline May & $1.72 \mathrm{E}-04$ & $2.28 \mathrm{E}-07$ & $9.62 \mathrm{E}-06$ & $2.50 \mathrm{E}+02$ & 2.15E-04 & $2.28 \mathrm{E}-07$ & $8.58 \mathrm{E}-06$ & $1.79 \mathrm{E}+02$ & $2.15 \mathrm{E}-04$ & 1.17E-05 & $1.42 \mathrm{E}+02$ & $1.99 \mathrm{E}-05$ & $8.01 \mathrm{E}+01$ \\
\hline June & $1.72 \mathrm{E}-04$ & $2.28 \mathrm{E}-07$ & $9.62 \mathrm{E}-06$ & $2.50 \mathrm{E}+02$ & 2.15E-04 & $2.28 \mathrm{E}-07$ & $8.58 \mathrm{E}-06$ & $1.79 \mathrm{E}+02$ & 2.15E-04 & 1.17E-05 & $1.42 \mathrm{E}+02$ & $1.99 \mathrm{E}-05$ & $8.01 \mathrm{E}+01$ \\
\hline July & $1.72 \mathrm{E}-04$ & $2.28 \mathrm{E}-07$ & $9.62 \mathrm{E}-06$ & $2.50 \mathrm{E}+02$ & 2.15E-04 & $2.28 \mathrm{E}-07$ & $8.68 \mathrm{E}-06$ & $1.79 \mathrm{E}+02$ & 2.15E-04 & $1.18 \mathrm{E}-05$ & $1.42 \mathrm{E}+02$ & 1.98E-05 & $8.01 E+01$ \\
\hline August & $1.72 \mathrm{E}-04$ & $2.28 \mathrm{E}-07$ & $9.62 \mathrm{E}-06$ & $2.50 \mathrm{E}+02$ & 2.15E-04 & $2.28 \mathrm{E}-07$ & $8.68 \mathrm{E}-06$ & $1.79 E+02$ & 2.15E-04 & 1.18E-05 & $1.42 \mathrm{E}+02$ & $1.98 \mathrm{E}-05$ & $8.01 E+01$ \\
\hline September & $1.72 \mathrm{E}-04$ & $2.28 \mathrm{E}-07$ & $9.62 \mathrm{E}-06$ & $2.50 \mathrm{E}+02$ & 2.15E-04 & $2.28 \mathrm{E}-07$ & $8.68 \mathrm{E}-06$ & $1.79 \mathrm{E}+02$ & 2.15E-04 & 1.18E-05 & $1.42 \mathrm{E}+02$ & 1.98E-05 & $8.01 E+01$ \\
\hline October & $1.72 \mathrm{E}-04$ & $2.28 \mathrm{E}-07$ & 9.62E-06 & $2.50 \mathrm{E}+02$ & 2.15E-04 & $2.28 \mathrm{E}-07$ & $8.59 \mathrm{E}-06$ & $1.79 \mathrm{E}+02$ & 2.15E-04 & 1.17E-05 & $1.42 \mathrm{E}+02$ & 1.97E-05 & $8.01 \mathrm{E}+01$ \\
\hline November & $1.72 \mathrm{E}-04$ & $2.28 \mathrm{E}-07$ & $9.62 \mathrm{E}-06$ & $2.50 \mathrm{E}+02$ & 2.15E-04 & $2.28 \mathrm{E}-07$ & $8.59 \mathrm{E}-06$ & $1.79 \mathrm{E}+02$ & 2.15E-04 & 1.17E-05 & $1.42 \mathrm{E}+02$ & 1.97E-05 & $8.01 \mathrm{E}+01$ \\
\hline December & $1.72 \mathrm{E}-04$ & $2.28 \mathrm{E}-07$ & $9.62 \mathrm{E}-06$ & $2.50 \mathrm{E}+02$ & 2.15E-04 & $2.28 \mathrm{E}-07$ & $8.59 \mathrm{E}-06$ & $1.79 \mathrm{E}+02$ & 2.15E-04 & 1.38E-05 & $1.42 \mathrm{E}+02$ & 1.93E-05 & $8.01 E+01$ \\
\hline
\end{tabular}

The structure of natural gas tariffs in DER-CAM is different than that of Tokyo Gas, so rates had to be approximated. The monthly maximum demand charge was estimated and added to the energy charge. The flow rate charge depends on capacity of the equipment. It was converted into $\$ / \mathrm{kW}$ and input as a standby charge ${ }^{2}$.

\footnotetext{
${ }^{2}$ Standby charges are charges proportional to the electrical capacity of the installed DER system. Utilities assert that this is the cost of providing access to additional utility electrical capacity for use during DER outages.
} 
In this report, commercial electricity and natural gas rates in Tokyo were used as the representative Japanese rates.

\subsection{DER Technology Information in Japan and the U.S.}

Table 8 shows United States DER technology data collected by Firestone (2004). It is itemized by natural gas engine (GE), gas turbine (GT), microturbine (MT), fuel cell (FC), and photovoltaic (PV). All equipment (besides PV) can be purchased for electricity generation only, and with heat recovery for heating $(\mathrm{HX})$, or with heat recovery for heating and absorption cooling (ABSHX). Numbers at the end of each name in Table 8 refer to the rated capacity of the equipment. Data includes capacity, lifetime (in years), turnkey capital costs, maintenance costs, heat rate, and electrical efficiency. 
The Potential for Distributed Generation in Japanese Prototype Buildings: English Version

Table 8: DER Technology Information for the U.S.

\begin{tabular}{|c|c|c|c|c|c|c|c|c|}
\hline Technology & Name & $\begin{array}{c}\text { Capacity } \\
\text { kW }\end{array}$ & $\begin{array}{l}\text { Lifetime } \\
\text { a }\end{array}$ & $\begin{array}{l}\text { Capital } \\
\text { Cost } \\
\$ / k W\end{array}$ & $\begin{array}{c}\text { Fixed Annual } \\
\text { Cost } \\
\$ / k W\end{array}$ & $\begin{array}{c}\text { Variable } \\
\text { Annual Cost } \\
\$ / \mathrm{kW}\end{array}$ & $\begin{array}{l}\text { Heat Rate } \\
\mathrm{kJ} / \mathrm{kWh}\end{array}$ & $\begin{array}{c}\text { HHV } \\
\text { Efficiency } \\
\%\end{array}$ \\
\hline \multirow[t]{5}{*}{ Fuel Cell } & FC--00200 & 200 & 10 & 5005 & 0 & 0.029 & 10000 & $36.00 \%$ \\
\hline & GT--01000 & 1000 & 20 & 1403 & 0 & 0.0096 & 16438 & $21.90 \%$ \\
\hline & GT--05000 & 5000 & 20 & 779 & 0 & 0.0059 & 13284 & $27.10 \%$ \\
\hline & GT--10000 & 10000 & 20 & 716 & 0 & 0.0055 & 12414 & $29.00 \%$ \\
\hline & GT--25000 & 25000 & 20 & 659 & 0 & 0.0049 & 10496 & $34.30 \%$ \\
\hline \multirow[t]{5}{*}{ Gas Turbine } & GT--40000 & 40000 & 20 & 592 & 0 & 0.0042 & 9730 & $37.00 \%$ \\
\hline & MT--00028 & 28 & 10 & 2263 & 0 & 0.015 & 15929 & $22.60 \%$ \\
\hline & MT--00060 & 60 & 10 & 1828 & 0 & 0.015 & 14400 & $25.00 \%$ \\
\hline & MT--00067 & 67 & 10 & 1708 & 0 & 0.015 & 14286 & $25.20 \%$ \\
\hline & MT--00076 & 76 & 10 & 1713 & 0 & 0.015 & 14876 & $24.20 \%$ \\
\hline \multirow{3}{*}{ Microturbine } & MT--00100 & 100 & 10 & 1576 & 0 & 0.015 & 13846 & $26.00 \%$ \\
\hline & NG--00030 & 30 & 20 & 1044 & 0 & 0.02 & 13080 & $27.52 \%$ \\
\hline & NG--00060 & 60 & 20 & 991 & 0 & 0.018 & 12528 & $28.74 \%$ \\
\hline \multirow{7}{*}{$\begin{array}{l}\text { Natual Gas } \\
\text { Reciprocating } \\
\text { Engine }\end{array}$} & NG--00075 & 75 & 20 & 974 & 0 & 0.017 & 12360 & $29.13 \%$ \\
\hline & NG--00100 & 100 & 20 & 1030 & 0 & 0.018 & 12000 & $30.00 \%$ \\
\hline & NG--00300 & 300 & 20 & 790 & 0 & 0.013 & 11613 & $31.00 \%$ \\
\hline & NG--01000 & 1000 & 20 & 720 & 0 & 0.009 & 10588 & $34.00 \%$ \\
\hline & NG--03000 & 3000 & 20 & 710 & 0 & 0.009 & 10286 & $35.00 \%$ \\
\hline & NG--05000 & 5000 & 20 & 695 & 0 & 0.008 & 9730 & $37.00 \%$ \\
\hline & PV--00010 & 10 & 30 & 8740 & 12 & 0 & 0 & $100.00 \%$ \\
\hline \multirow{3}{*}{ Photovoltaic } & PV--00025 & 25 & 30 & 8140 & 12 & 0 & 0 & $100.00 \%$ \\
\hline & PV--00050 & 50 & 30 & 7940 & 12 & 0 & 0 & $100.00 \%$ \\
\hline & PV--00100 & 100 & 30 & 7840 & 12 & 0 & 0 & $100.00 \%$ \\
\hline \multicolumn{9}{|l|}{ Fuel Cell with } \\
\hline \multirow[t]{2}{*}{$\begin{array}{l}\text { Heat Recovery } \\
\text { for Heating }\end{array}$} & FC--HX--00200 & 200 & 10 & 5200 & 0 & 0.029 & 10000 & $36.00 \%$ \\
\hline & GT--HX--01000 & 1000 & 20 & 1910 & 0 & 0.0096 & 16438 & $21.90 \%$ \\
\hline \multirow{5}{*}{$\begin{array}{l}\text { Gas Turbine } \\
\text { with Heat } \\
\text { Recovery for } \\
\text { Heating }\end{array}$} & GT--HX--05000 & 5000 & 20 & 1024 & 0 & 0.0059 & 13284 & $27.10 \%$ \\
\hline & GT--HX--10000 & 10000 & 20 & 928 & 0 & 0.0055 & 12414 & $29.00 \%$ \\
\hline & GT--HX--25000 & 25000 & 20 & 800 & 0 & 0.0049 & 10496 & $34.30 \%$ \\
\hline & GT--HX--40000 & 40000 & 20 & 702 & 0 & 0.0042 & 9730 & $37.00 \%$ \\
\hline & MT--HX--00028 & 28 & 10 & 2636 & 0 & 0.015 & 15929 & $22.60 \%$ \\
\hline \multirow{4}{*}{$\begin{array}{l}\text { Microturbine } \\
\text { with Heat } \\
\text { Recovery for } \\
\text { Heating }\end{array}$} & MT--HX--00060 & 60 & 10 & 2082 & 0 & 0.015 & 14400 & $25.00 \%$ \\
\hline & MT--HX--00067 & 67 & 10 & 1926 & 0 & 0.015 & 14286 & $25.20 \%$ \\
\hline & MT--HX--00076 & 76 & 10 & 1932 & 0 & 0.015 & 14876 & $24.20 \%$ \\
\hline & MT--HX--00100 & 100 & 10 & 1769 & 0 & 0.015 & 13846 & $26.00 \%$ \\
\hline \multirow{8}{*}{$\begin{array}{l}\text { Gas Engine } \\
\text { Heat Recovery } \\
\text { for Heating }\end{array}$} & NG--HX--00030 & 30 & 20 & 1442 & 0 & 0.02 & 13080 & $27.52 \%$ \\
\hline & NG--HX--00060 & 60 & 20 & 1362 & 0 & 0.018 & 12528 & $28.74 \%$ \\
\hline & NG--HX--00075 & 75 & 20 & 1336 & 0 & 0.017 & 12360 & $29.13 \%$ \\
\hline & NG--HX--00100 & 100 & 20 & 1350 & 0 & 0.018 & 12000 & $30.00 \%$ \\
\hline & NG--HX--00300 & 300 & 20 & 1160 & 0 & 0.013 & 11613 & $31.00 \%$ \\
\hline & NG--HX--01000 & 1000 & 20 & 945 & 0 & 0.009 & 10588 & $34.00 \%$ \\
\hline & NG--HX--03000 & 3000 & 20 & 935 & 0 & 0.009 & 10286 & $35.00 \%$ \\
\hline & NG--HX--05000 & 5000 & 20 & 890 & 0 & 0.008 & 9730 & $37.00 \%$ \\
\hline \multicolumn{9}{|l|}{$\begin{array}{l}\text { Fuel Cell with } \\
\text { Heating and }\end{array}$} \\
\hline \multirow[t]{3}{*}{ Cooling } & FC--ABSHX--00200 & 200 & 10 & 5366 & 9.69 & 0.029 & 10000 & $36.00 \%$ \\
\hline & GT--ABSHX--01000 & 1000 & 20 & 2137 & 10.37 & 0.0096 & 16438 & $21.90 \%$ \\
\hline & GT--ABSHX--05000 & 5000 & 20 & 1149 & 4.03 & 0.0059 & 13284 & $27.10 \%$ \\
\hline \multirow{4}{*}{$\begin{array}{l}\text { Gas Turbine } \\
\text { with Heating } \\
\text { and Cooling }\end{array}$} & GT--ABSHX--10000 & 10000 & 20 & 1025 & 2.76 & 0.0055 & 12414 & $29.00 \%$ \\
\hline & GT--ABSHX--25000 & 25000 & 20 & 859 & 2.12 & 0.0049 & 10496 & $34.30 \%$ \\
\hline & GT--ABSHX--40000 & 40000 & 20 & 746 & 1.88 & 0.0042 & 9730 & $37.00 \%$ \\
\hline & MT--ABSHX--00028 & 28 & 10 & 3046 & 23.49 & 0.015 & 15929 & $22.60 \%$ \\
\hline & MT--ABSHX--00060 & 60 & 10 & 2420 & 19.5 & 0.015 & 14400 & $25.00 \%$ \\
\hline Microturbine & MT--ABSHX--00067 & 67 & 10 & 2201 & 15.87 & 0.015 & 14286 & $25.20 \%$ \\
\hline with Heating & MT--ABSHX--00076 & 76 & 10 & 2225 & 16.92 & 0.015 & 14876 & $24.20 \%$ \\
\hline and Cooling & MT--ABSHX--00100 & 100 & 10 & 2015 & 14.27 & 0.015 & 13846 & $26.00 \%$ \\
\hline & NG--ABSHX--00030 & 30 & 20 & 2029 & 22.56 & 0.02 & 13080 & $27.52 \%$ \\
\hline & NG--ABSHX--00060 & 60 & 20 & 1851 & 18.93 & 0.018 & 12528 & $28.74 \%$ \\
\hline & NG--ABSHX--00075 & 75 & 20 & 1796 & 17.84 & 0.017 & 12360 & $29.13 \%$ \\
\hline Gas Engine & NG--ABSHX--00100 & 100 & 20 & 1774 & 16.51 & 0.018 & 12000 & $30.00 \%$ \\
\hline and Cooling & NG--ABSHX--00300 & 300 & 20 & 1465 & 12.08 & 0.013 & 11613 & $31.00 \%$ \\
\hline & NG--ABSHX--01000 & 1000 & 20 & 1117 & 6.97 & 0.009 & 10588 & $34.00 \%$ \\
\hline & NG--ABSHX--03000 & 3000 & 20 & 1038 & 4.37 & 0.009 & 10286 & $35.00 \%$ \\
\hline & NG--ABSHX--05000 & 5000 & 20 & 967 & 3.45 & 0.008 & 9730 & $37.00 \%$ \\
\hline
\end{tabular}


For this study, data was collected on Japanese DER equipment (Table 9). Figure 22 compares DER turnkey costs in Japan and the U.S. There is little difference in the range 3,000 kW to $5,000 \mathrm{~kW}$. At higher capacities Japanese prices are lower, while at the lower capacities, Japanese prices are significantly higher.

Table 9: Japanese DER Technology Information (Only With Waste Heat Recovery)

\begin{tabular}{|c|c|c|c|c|c|c|c|c|c|}
\hline & Technology & $\begin{array}{l}\text { Capacity } \\
\text { (kW) }\end{array}$ & $\begin{array}{l}\text { Lifetime } \\
\text { (a) }\end{array}$ & $\begin{array}{c}\text { CapCost } \\
(\$ / k W)\end{array}$ & $\begin{array}{l}\text { Maintenance } \\
\text { Cost }(\$ / \mathrm{kW})\end{array}$ & $\begin{array}{c}\text { Power } \\
\text { Generation } \\
\text { Efficiency } \\
(\%)\end{array}$ & $\begin{array}{c}\text { Total } \\
\text { Efficiency } \\
(\%)\end{array}$ & $\begin{array}{c}\text { Heat } \\
\text { Recovery } \\
\text { Efficiency } \\
(\%)\end{array}$ & $\begin{array}{l}\text { Annual } \\
\text { Operation } \\
\text { Hour(h) }\end{array}$ \\
\hline \multirow{6}{*}{ Average } & \multirow{5}{*}{ Gas Engine } & 10 & 15 & 3333.33 & 0.02 & 26 & 82.5 & 56.5 & 4000 \\
\hline & & 210 & 15 & 2083.33 & 0.03 & 32.6 & 86.8 & 54.2 & 4000 \\
\hline & & 610 & 15 & 1666.67 & 0.02 & 40.8 & 75 & 34.2 & 4000 \\
\hline & & 815 & 15 & 1500.00 & 0.02 & 40.8 & 74 & 33.2 & 4000 \\
\hline & & 2383 & 15 & 1083.33 & 0.02 & 41.1 & 74.8 & 33.7 & 4000 \\
\hline & Gas Turbine & 3770 & 15 & 916.67 & 0.01 & 27.5 & 72.1 & 44.6 & 7000 \\
\hline \multirow{8}{*}{$\begin{array}{l}\text { Company } \\
\text { MITSUYI }\end{array}$} & \multirow{8}{*}{$\begin{array}{c}\text { Gas Turbine } \\
\text { CHP }\end{array}$} & 3370 & 15 & 1186.94 & 0.01 & & & 47.8 & \\
\hline & & 4420 & 15 & 980.39 & 0.01 & & & 51.4 & \\
\hline & & 5300 & 15 & 864.78 & 0.01 & & & 50.9 & \\
\hline & & 7260 & 15 & 757.58 & 0.01 & & & 47.5 & \\
\hline & & 9090 & 15 & 687.57 & 0.01 & & & 48.7 & \\
\hline & & 10310 & 15 & 646.62 & 0.01 & & & 49.4 & \\
\hline & & 1090 & 15 & 1529.05 & 0.01 & & & 46.2 & \\
\hline & & 1270 & 15 & 1377.95 & 0.01 & & & 30.4 & \\
\hline
\end{tabular}

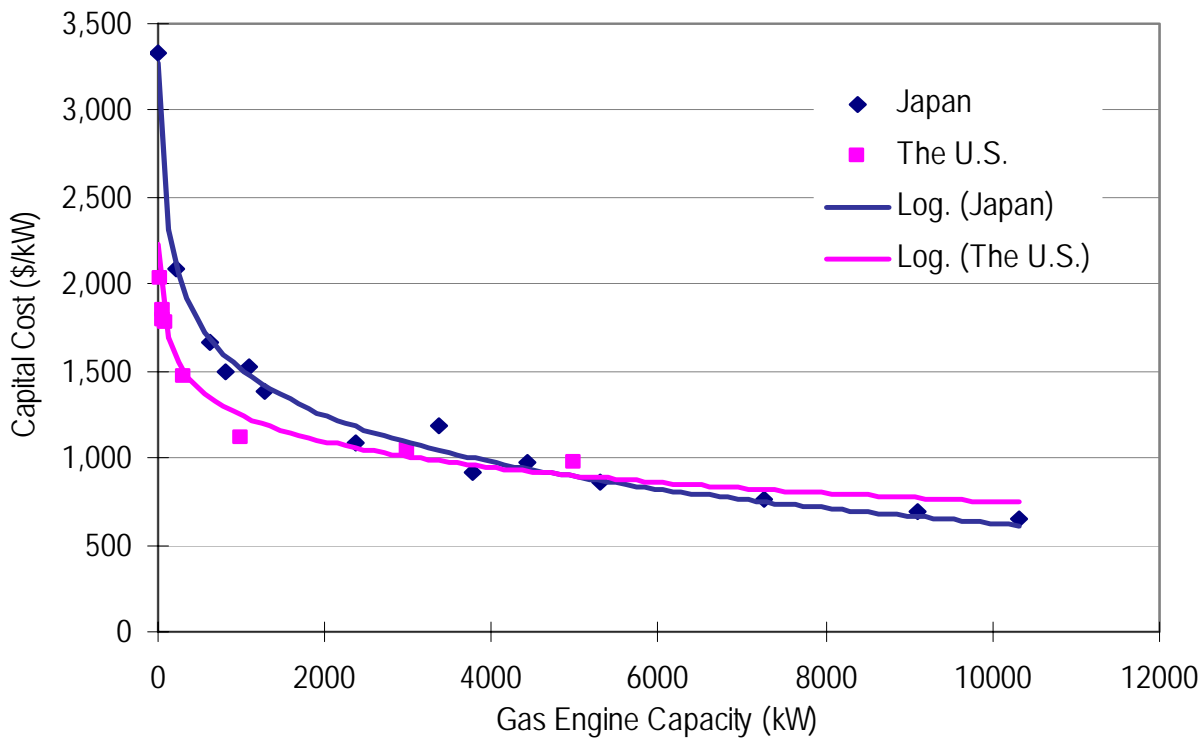

Figure 22: Comparison of turnkey CHP costs in Japan and the U.S. 
Because CHP subsidies of 1/3 of turnkey costs are available throughout Japan, making DER costs become similar to those in the United States. U.S. technology information was used. A sensitivity analysis was also done without the Japanese subsidy, for which the United States costs were multiplied by 1.5 .

\subsection{Incentives for DER Installation}

\subsubsection{The U.S. DER Incentives}

There is no single incentive for DER installation in the U.S., rather it varies by state and region, and can include rebates and low-interest loans. Historically under federal law and Federal Energy Regulatory Committee (FERC) regulations, individual states determine incentives for qualifying facilities (QFs) which includes larger (> 1 MW) CHP plants in their state. Small scale CHP is entirely under state and local jurisdiction on incentives may include rebates on DER project costs, energy tariff reductions, or utility purchase of excess electricity. Determining which incentives were available to each site proved difficult. In the work by Bailey (2003), organizations contacted included FERC, the New York State Public Service Commission (NYPSC), the Long Island Power Authority (LIPA), KeySpan, the California Energy Commission (CEC), the California Public Utilities Commission (CPUC), Pacific Gas and Electric (PG\&E), Southern California Edison (SCE), San Diego Gas and Electric (SDG\&E), and various energy consultants.

Clearly, presentation of any comprehensive picture of U.S. DER incentives is not possible here, so that example programs one from California, one from New York and one federal are described.

\subsubsection{CPUC}

As part of California Assembly Bill 970, the CPUC introduced a statewide self-generation incentive program in September 2000. It provides financial incentives to customers that install new qualifying self-generation equipment to provide all or a portion of their electricity needs. Funding of \$125 million annually statewide provided is for self-generation up to $1 \mathrm{MW}$. The program is administered by PG\&E, SCE, SoCalGas and the San Diego Regional Energy Office (SDREO, serving SDG\&E customers).

Eligible technologies include MTs, FCs, PVs, small GTs, wind turbines, and internal combustion engines that meet the following criteria:

- At least 5\% of the power system's total energy output is in the form of useful thermal energy.

- Where useful thermal energy results from power production, the useful annual electrical output plus one-half the annual useful thermal energy output equals not less than $42.5 \%$ of any natural gas and oil energy input.

- In the case of microturbines, small gas turbines, and internal combustion engines, the following power quality and reliability requirements must be met:

- The self-generating facility must be designed to operate at a power factor between 0.95 power factor loading and 0.90 power factor leading. 
- Sites with greater than $200 \mathrm{~kW}$ generating capability must coordinate maintenance schedules with the local utility, and in general, can only schedule maintenance from October to March, or only during off peak or weekend hours between April and September.

Funding from this program is available as a secondary source after other sources have been fully tapped. The CPUC funding limits are decreased by the amount of alternate funding. In other words, the limits set out by the CPUC represent a cap to funding available to qualifying sites in California. It is assumed, therefore, that the test sites located in California that indicated they are applying for or have received CPUC self-generation funding are qualifying facilities, and will receive funding up to the limits set by the CPUC in this program (Table 10) .

Table 10: CPUC DER Incentives

\begin{tabular}{|c|c|c|c|c|l|}
\hline $\begin{array}{c}\text { Incentive } \\
\text { Category }\end{array}$ & $\begin{array}{c}\text { Incentive } \\
\text { Offered }\end{array}$ & $\begin{array}{c}\text { Maximum } \\
\text { \% of } \\
\text { Project }\end{array}$ & $\begin{array}{c}\text { Minimum } \\
\text { System Size }\end{array}$ & $\begin{array}{c}\text { Maximum } \\
\text { System } \\
\text { Size* }\end{array}$ & $\begin{array}{c}\text { Eligible } \\
\text { Technologies }\end{array}$ \\
\hline Level 1 & $\$ 4500 / \mathrm{kW}$ & $50 \%$ & $30 \mathrm{~kW}$ & $1.5 \mathrm{MW}$ & $\begin{array}{l}\text { PVs, FCs operating on renewable fuel, } \\
\text { and wind turbines }\end{array}$ \\
\hline Level 2 & $\$ 2500 / \mathrm{kW}$ & $40 \%$ & None & $1.5 \mathrm{MW}$ & $\begin{array}{l}\text { FCs operating on non-renewable fuel } \\
\text { and utilizing sufficient waste heat } \\
\text { recovery }\end{array}$ \\
\hline Level 3 & $\$ 1000 / \mathrm{kW}$ & $30 \%$ & None & $1.5 \mathrm{MW}$ & $\begin{array}{l}\text { MTs, small GTs, internal } \\
\text { combustion engines, using sufficient } \\
\text { waste heat recovery and meeting } \\
\text { reliability criteria }\end{array}$ \\
\hline
\end{tabular}

\subsubsection{New York State Funding for Energy Efficiency and DER}

In New York State, the NYPSC has implemented a system benefits charge (SBC) applied to all electric rates to provide a fund for the purposes of increasing energy efficiency and providing public goods programs. The program has been expanded to include transmission and distribution issues due to the increasing difficulty of providing energy services to "load pockets." $75 \%$ if funds collected by the SBC are distributed to the New York State Energy Research and Development Authority (NYSERDA), and the remainder goes electric utilities for their own programs. NYSERDA's programs are called “Energy\$mart” and include low interest loans, and targeted energy efficiency programs for schools, agriculture, homes, communities, and pollution control and monitoring for air water and solid waste emissions.

NYSERDA offers funding for projects that demonstrate the use of DER technologies in industrial, commercial, municipal, and institutional organizations. NYSERDA's DER programs provide approximately $\$ 12$ million annually statewide for 2002 through 2006 (Table 11). 
Table 11: NYSERDA's DER program

\begin{tabular}{|l|l|l|l|}
\hline Funding Allocation & $\mathbf{2 0 0 1}$ & $\mathbf{2 0 0 2 - 2 0 0 6}$ & Total \\
\hline $\begin{array}{l}\text { Distributed Generation } \\
\text { Combined Heat and Power }\end{array}$ & $\$ 8,637,233$ & $\$ 58,445,839$ & $\$ 67,083,072$ \\
\hline
\end{tabular}

\subsubsection{Climate Change Fuel Cell program}

The DOD’s Climate Change Fuel Cell program was initiated in 1995 and provides up to $\$ 1,000 / \mathrm{kW}$ for fuel cell installations with a capacity of at least $3 \mathrm{~kW}$. The fund is administered through the US Army Corps of Engineers Construction Engineering Research Lab (CERL). The funding level for fiscal year 2002 was expected to be $\$ 3$ million.

Table 12 shows several incentives that apply to different sites as shown above. Although overall numbers cannot be cited, many sites still can receive incentives. 


\subsubsection{Incentives in Japan}

\begin{tabular}{|c|c|c|c|c|}
\hline & $\begin{array}{l}\text { Installed } \\
\text { Technology }\end{array}$ & Project Cost & $\begin{array}{l}\text { Grants } \\
\text { Received }\end{array}$ & Grants Rate \\
\hline$A \& P$ & $\begin{array}{l}60 \mathrm{~kW} \text { Capstone } \\
\text { microturbine,CHP for space } \\
\text { heating \&desiccant } \\
\text { dehumidification } \\
\end{array}$ & $\$ 145,000$ & $\$ 95,000$ & $66 \%$ \\
\hline $\begin{array}{l}\text { USPS } \\
\text { Absorption } \\
\text { Cooling }\end{array}$ & & $\$ 680,000$ & $\begin{array}{l}\$ 0 \text { (project not porsued) } \\
(\$ 204,000 \\
\text { potential) }\end{array}$ & $30 \%$ \\
\hline $\begin{array}{l}\text { Guarantee } \\
\text { Savings } \\
\text { Building }\end{array}$ & $\begin{array}{l}3 \times 200 \mathrm{~kW} \text { Phosphoric Acid } \\
\text { Fuel Cells, CHP,350 kW } \\
\text { (100ton) adsorption chiller }\end{array}$ & $\$ 4,353,375$ & $\begin{array}{l}\text { SELFGEN, CPUC benefits } \\
\text { through PG\&E } \$ 1.5 \text { million } \\
\text { DODCCFC Grant } \\
\$ 600,000 \text {, loan for } \$ 2.6 \text { million } \\
\text { from UTC }\end{array}$ & $48 \%$ \\
\hline AA Dairy & $\begin{array}{l}\text { Digester biogas system } \\
\text { converted 130kW diesel } \\
\text { engine }\end{array}$ & $\begin{array}{l}\$ 363,000 \$ 61,000 \\
\text { without digester } \\
\text { system }\end{array}$ & $\begin{array}{l}\text { EPA Ag Star } \$ 24,000, \text { local } \\
\text { Soil Conservation District } \\
\$ 120,000\end{array}$ & $40 \%$ \\
\hline $\begin{array}{l}\text { East Bay } \\
\text { Municipal } \\
\text { Utility } \\
\text { District }\end{array}$ & $\begin{array}{l}10 \times 60 \mathrm{~kW} \text { Capstone } \\
\text { microturbines,150 ton } \\
\text { absorption chiller and CHP }\end{array}$ & $\begin{array}{l}\$ 3,900,000 \text { (total } \\
\text { funding) } \\
\$ 184,522 \text { for } \\
\text { absorption chiller and } \\
\text { heat exchanger }\end{array}$ & $\begin{array}{l}\$ 855,000 \text { rebate, and } \\
\$ 1.9 \text { million low interest loan }\end{array}$ & $22 \%$ \\
\hline $\begin{array}{l}\text { Wyoming } \\
\text { County } \\
\text { Community } \\
\text { Hospital }\end{array}$ & $\begin{array}{l}560 \mathrm{~kW} \text { natural gas engine } \\
\text { with CHP and absorption } \\
\text { cooling }\end{array}$ & $\$ 1,013,690$ & $\begin{array}{l}\text { NYSERD A funded } 50 \% \text { of } \\
\$ 25,000 \text { feasibility study }\end{array}$ & \\
\hline $\begin{array}{l}\text { Byron } \\
\text { Bergen } \\
\text { (upstate NY } \\
\text { school) }\end{array}$ & $\begin{array}{l}8 \text { different engines. 7diesel, } \\
1 \text { natural gas, 2absorption } \\
\text { chillers, onsite natural gas } \\
\text { well andtwo boilers.1450 kW } \\
\text { total Grid independent }\end{array}$ & $\$ 3$ million & $\begin{array}{l}\$ 2,760,000 \text { State rebates for } \\
\text { capital projects } \\
\text { atschools. Taxpayer direct } \\
\text { cost was } \$ 240,000\end{array}$ & $92 \%$ \\
\hline
\end{tabular}

Table 13 shows interest rates as low as $1.65 \%$ for CHP installation. Table 15 shows details of available subsidies. In general, 1/3 of the installation cost will be subsidized. 
Table 12: Grants for DG in Selected Site in the U.S.

\begin{tabular}{|c|c|c|c|c|}
\hline & $\begin{array}{l}\text { Installed } \\
\text { Technology }\end{array}$ & Project Cost & $\begin{array}{l}\text { Grants } \\
\text { Received }\end{array}$ & Grants Rate \\
\hline$A \& P$ & $\begin{array}{l}60 \mathrm{~kW} \text { Capstone } \\
\text { microturbine,CHP for space } \\
\text { heating \&desiccant } \\
\text { dehumidification }\end{array}$ & $\$ 145,000$ & $\$ 95,000$ & $66 \%$ \\
\hline $\begin{array}{l}\text { USPS } \\
\text { Absorption } \\
\text { Cooling }\end{array}$ & & $\$ 680,000$ & $\begin{array}{l}\$ 0 \text { (project not porsued) } \\
(\$ 204,000 \\
\text { potential) }\end{array}$ & $30 \%$ \\
\hline $\begin{array}{l}\text { Guarantee } \\
\text { Savings } \\
\text { Building }\end{array}$ & $\begin{array}{l}3 \times 200 \text { kW Phosphoric Acid } \\
\text { Fuel Cells, CHP, } 350 \text { kW } \\
\text { (100ton) adsorption chiller }\end{array}$ & $\$ 4,353,375$ & $\begin{array}{l}\text { SELFGEN, CPUC benefits } \\
\text { through PG\&E } \$ 1.5 \text { million } \\
\text { DODCCFC Grant } \\
\$ 600,000 \text {, loan for } \$ 2.6 \text { million } \\
\text { from UTC }\end{array}$ & $48 \%$ \\
\hline AA Dairy & $\begin{array}{l}\text { Digester biogas system } \\
\text { converted } 130 \mathrm{~kW} \text { diesel } \\
\text { engine }\end{array}$ & $\begin{array}{l}\$ 363,000 \$ 61,000 \\
\text { without digester } \\
\text { system }\end{array}$ & $\begin{array}{l}\text { EPA Ag Star } \$ 24,000, \text { local } \\
\text { Soil Conservation District } \\
\$ 120,000\end{array}$ & $40 \%$ \\
\hline $\begin{array}{l}\text { East Bay } \\
\text { Municipal } \\
\text { Utility } \\
\text { District }\end{array}$ & $\begin{array}{l}10 \times 60 \mathrm{~kW} \text { Capstone } \\
\text { microturbines, } 150 \text { ton } \\
\text { absorption chiller and CHP }\end{array}$ & $\begin{array}{l}\$ 3,900,000 \text { (total } \\
\text { funding) } \\
\$ 184,522 \text { for } \\
\text { absorption chiller and } \\
\text { heat exchanger }\end{array}$ & $\begin{array}{l}\$ 855,000 \text { rebate, and } \\
\$ 1.9 \text { million low interest loan }\end{array}$ & $22 \%$ \\
\hline $\begin{array}{l}\text { Wyoming } \\
\text { County } \\
\text { Community } \\
\text { Hospital }\end{array}$ & $\begin{array}{l}560 \mathrm{~kW} \text { natural gas engine } \\
\text { with } \mathrm{CHP} \text { and absorption } \\
\text { cooling }\end{array}$ & $\$ 1,013,690$ & $\begin{array}{l}\text { NYSERD A funded } 50 \% \text { of } \\
\$ 25,000 \text { feasibility study }\end{array}$ & \\
\hline $\begin{array}{l}\text { Byron } \\
\text { Bergen } \\
\text { (upstate NY } \\
\text { school) }\end{array}$ & $\begin{array}{l}8 \text { different engines. 7diesel, } \\
\text { 1natural gas, 2absorption } \\
\text { chillers, onsite natural gas } \\
\text { well andtwo boilers.1450 kW } \\
\text { total Grid independent }\end{array}$ & $\$ 3$ million & $\begin{array}{l}\$ 2,760,000 \text { State rebates for } \\
\text { capital projects } \\
\text { atschools. Taxpayer direct } \\
\text { cost was } \$ 240,000\end{array}$ & $92 \%$ \\
\hline
\end{tabular}

Table 13 Financial Loan for CHP Installation in Japan

\begin{tabular}{|c|c|c|}
\hline Program Name & Objective & Content \\
\hline New Energy Installation Promotion & $\begin{array}{l}\text { equipment over } 100 \mathrm{~kW} \text {, efficiency } \\
\text { greater than } 60 \% \mathrm{FC}\end{array}$ & $\begin{array}{l}\text { Interest rate } 1.65 \% \\
\text { Subsidy } 40 \% \text { of investment }\end{array}$ \\
\hline Energy Conservation Promotion & $\begin{array}{l}\text { equipment over } 50 \mathrm{~kW} \text {, efficiency } \\
\text { greater than } 60 \%, \mathrm{CHP} \text { (any type of } \\
\text { fuel) }\end{array}$ & $\begin{array}{l}\text { Interest rate } 1.65 \% \\
\text { Subsidy } 50 \% \text { of investment }\end{array}$ \\
\hline $\begin{array}{l}\text { New Power Generation/Distribution } \\
\text { Enterprises }\end{array}$ & $\begin{array}{l}\text { Electricity generation, transmission, } \\
\text { distribution enterprise }\end{array}$ & $\begin{array}{l}\text { Interest rate } 1.55-1.65 \% \\
\text { Subsidy } 50 \% \text { of investment }\end{array}$ \\
\hline
\end{tabular}


Table 14: Subsidy for CHP in Japan

\begin{tabular}{|c|c|c|}
\hline Policy & Objective & Content \\
\hline $\begin{array}{l}\text { The New Energy and Industrial } \\
\text { Technology Development Organization } \\
\text { (NEDO) : } \\
\text { Rational Energy Utilization Enterprise } \\
\text { Support Project }\end{array}$ & $\begin{array}{l}\text { Office building ESCO project and using } \\
\text { Natural Gas with CHP installation } \\
\text { project, must be conducted by private } \\
\text { enterprise }\end{array}$ & $\begin{array}{l}\text { Subsidy: no more than } 1 / 3 \text { of } \\
\text { cost, up to } 500 \text { million } ¥ \text { ( } 5 \\
\text { million dollars) }\end{array}$ \\
\hline $\begin{array}{l}\text { Minister of Economy, Trade and } \\
\text { Industry (METI): } \\
\text { New Energy Enterprise Support Project }\end{array}$ & $\begin{array}{l}\text { High efficiency natural gas CHP } \\
\text { system, Natural gas co-gen utilization } \\
\text { energy supply equipment }\end{array}$ & $\begin{array}{l}\text { Subsidy: no more than } 1 / 3 \text { of } \\
\text { cost, bond covered up to } \\
90 \%\end{array}$ \\
\hline $\begin{array}{l}\text { NEDO: } \\
\text { Local New Energy Installation } \\
\text { Promotion Enterprise }\end{array}$ & $\begin{array}{l}\text { Local govt. (public) organization: } \\
\text { project conducted by local public org. } \\
\text { and high efficiency CHP system, } \\
\text { Natural gas CHP utilization energy } \\
\text { supply equipment }\end{array}$ & $\begin{array}{l}\text { Subsidy: no more than } 1 / 2 \text { of } \\
\text { cost }\end{array}$ \\
\hline $\begin{array}{l}\text { NEDO: } \\
\text { Local Energy Conservation Promotion } \\
\text { Enterprise }\end{array}$ & $\begin{array}{l}\text { Local govt .(public) organization:: high } \\
\text { effectiveness demonstration, energy } \\
\text { conservation promotion measure }\end{array}$ & $\begin{array}{l}\text { Subsidy: no more than } 1 / 2 \text { of } \\
\text { cost }\end{array}$ \\
\hline $\begin{array}{l}\text { NEDO: } \\
\text { Global Warming Prevention Support } \\
\text { Enterprise }\end{array}$ & $\begin{array}{l}\text { New energy equipment and energy } \\
\text { conservation equipment and the } \\
\text { combination - installation of multiple } \\
\text { equipment such as new energy } \\
\text { equipment and energy conservation } \\
\text { equipment }\end{array}$ & $\begin{array}{l}\text { Subsidy: no more than } 1 / 2 \text { of } \\
\text { cost }\end{array}$ \\
\hline $\begin{array}{l}\text { METI: } \\
\text { Disaster Response Oil Supply Facility } \\
\text { Promotion }\end{array}$ & $\begin{array}{l}\text { Gasoline station generator more than } 10 \\
\mathrm{~kW} \text { Internal combustion power } \\
\text { generator }\end{array}$ & $\begin{array}{l}\text { Subsidy: } 1 / 5 \text { of the capital } \\
\text { cost (installation and equip), } \\
\text { up to } 500 \text { million } ¥ \text { ( } 5 \\
\text { million dollars) }\end{array}$ \\
\hline $\begin{array}{l}\text { LP (Liquefied Petroleum Gas } \\
\text { Promotion Center) (this is an } \\
\text { organization): } \\
\text { Petroleum gas energy utilization system } \\
\text { installation enterprise (the company that } \\
\text { installs these systems) }\end{array}$ & $\begin{array}{l}\text { Civic (non-industrial) sector: office } \\
\text { building/facility used for civic sector or } \\
\text { office, gas turbine, gas engine, single } \\
\text { unit with more than } 250 \mathrm{~kW} \text {. FCs over } \\
100 \mathrm{~kW} \text {. }\end{array}$ & $\begin{array}{l}\text { Subsidy: for GT, NG, } 1 / 2 \text { of } \\
\text { the expenses up to } 60 \\
\text { million } ¥ \text { ( } 600 \mathrm{~K} \text { dollars), } \\
\text { Fuel Cell } 1 / 2 \text { up to } 52 \text { million } \\
¥ \text { ( } 520 \mathrm{~K} \text { dollars) }\end{array}$ \\
\hline $\begin{array}{l}\text { Petroleum Industry Activation Center: } \\
\text { Advanced Petroleum Gas Energy } \\
\text { Utilization System Enterprise }\end{array}$ & $\begin{array}{l}\text { Single unit over } 500 \mathrm{~kW} \text { total unit over } \\
1000 \mathrm{~kW} \text { for non-industrial use } \\
\text { (petroleum cogeneration equipment) }\end{array}$ & $\begin{array}{l}1 / 2 \text { of capital cost up to } 400 \\
\text { million } ¥ \text { ( } 4 \text { million dollars) }\end{array}$ \\
\hline $\begin{array}{l}\text { Ministry of Land, Infrastructure and } \\
\text { Transport: } \\
\text { Ecological Housing District } \\
\text { (neighborhood) Model Enterprise }\end{array}$ & $\begin{array}{l}\text { Housing area- must have more than } 50 \\
\text { households qualify the guidelines of an } \\
\text { ecological housing district, have } \\
\text { cogeneration system }\end{array}$ & $\begin{array}{l}1 / 3 \text { of the facility } \\
\text { infrastructure expense }\end{array}$ \\
\hline $\begin{array}{l}\text { Local Goverment (Ministry of Health, } \\
\text { Labour and Welfare): } \\
\text { Emergency medical security disaster } \\
\text { infrastructure/establishment for hospital } \\
\text { to ensure emergency medical care } \\
\text { during disasters }\end{array}$ & $\begin{array}{l}\text { Disaster medical center, local disaster } \\
\text { medical center that use independent } \\
\text { energy system (like self generator). }\end{array}$ & $\begin{array}{l}\text { national or local govt } \\
\text { subsidizes } 1 / 3 \text { of the capital } \\
\text { cost up to } 1 \text { facility: } 178 \\
\text { million } ¥ \text { (1.8 million } \\
\text { dollars) }\end{array}$ \\
\hline
\end{tabular}




\section{Results}

This chapter presents results of the DER-CAM optimizations. As described in Section 3.2, the five prototype buildings considered are office building, hospital, hotel, retail and sports facility. All buildings were considered in 5,000 $\mathrm{m}^{2}$ and $10,000 \mathrm{~m}^{2}$ floor area sizes. Customer end use load data is from Kashiwagi (2002). For all DER-CAM scenarios, a real interest rate of 5\% is used. In many cases, sites would be eligible for loans with lower interest rates.

For all building types and sizes, separate DER-CAM optimizations were done using subsidized and non-subsidized DER capital costs. Commercial electricity and natural gas rates in Tokyo were used as the representative Japanese rates. The average efficiency of the Japanese macrogrid was assumed to be $36.6 \%{ }^{3}$. $\mathrm{CO}_{2}$ emissions were assumed to be $0.66 \mathrm{~kg} / \mathrm{kWh}$ (fossil fuels, only) ${ }^{4}$. This is equivalent to carbon emissions of $0.18 \mathrm{~kg} / \mathrm{kWh}$.

In the results whole system efficiency is the percentage of energy from fuel used by the DER system that is applied to an end use in the form of electricity or heat. In the United States, the Federal Energy Regulatory Commission (FERC) uses an alternative definition of efficiency, herein referred to as the FERC efficiency, which is defined as:

FERC Efficiency $=\frac{[\text { Electrical Energy Produced }]+\frac{1}{2}[\text { Recovered Heat Utilized }]}{[\text { HHU of Fuel Consumed }]} \times 100 \%$

\section{1 $10,000 \mathrm{~m}^{2}$ Buildings}

For each building type modeled, three DER-CAM scenarios were considered:

- Do-Nothing: No DER investments are considered. This scenario provides the annual energy cost, consumption, and emissions prior to DER investment.

- DER: DER investment in electricity generation only, no CHP.

- DER with CHP: DER investment in any of the electricity generation and heat recovery and utilization devices mentioned in Chapter 3.4

The results of these studies are described below.

\subsubsection{Office Building}

Table 15 shows the DER-CAM results for the office building. The Do-Nothing total energy bill is $\$ 317,400$. In the DER without heat recovery scenario, a $300 \mathrm{~kW}$ natural gas engine was selected, resulting in decreased electricity purchase and increased natural gas purchase. Total annual fuel costs (electricity and natural gas) are reduced by $16.2 \%$ and the total annual energy costs (including the capital and maintenance costs) are reduced by $4.7 \%(\$ 15,000)$. The payback period is 6 years.

\footnotetext{
3 According to Nippon Engine Generator Association (NEGA), http://www.nega.or.jp/

${ }^{4}$ Based on the assumption of Japan Ministry of Environment, http://www.env.go.jp/council/06earth/r062-01/index.html.
} 
For the DER with CHP scenario, the $300 \mathrm{~kW}$ natural gas engine with heat recovery for heating and absorption cooling was chosen. Compared with the Do-Nothing case, the total annual energy bill savings are $12.3 \%(\$ 40,000)$ with a payback period of 4.7 years. Total annual fuel costs are reduced by $30.3 \%$. CHP installation has sufficient economic benefit.

\section{Table 15: Office Building DER-CAM Results}

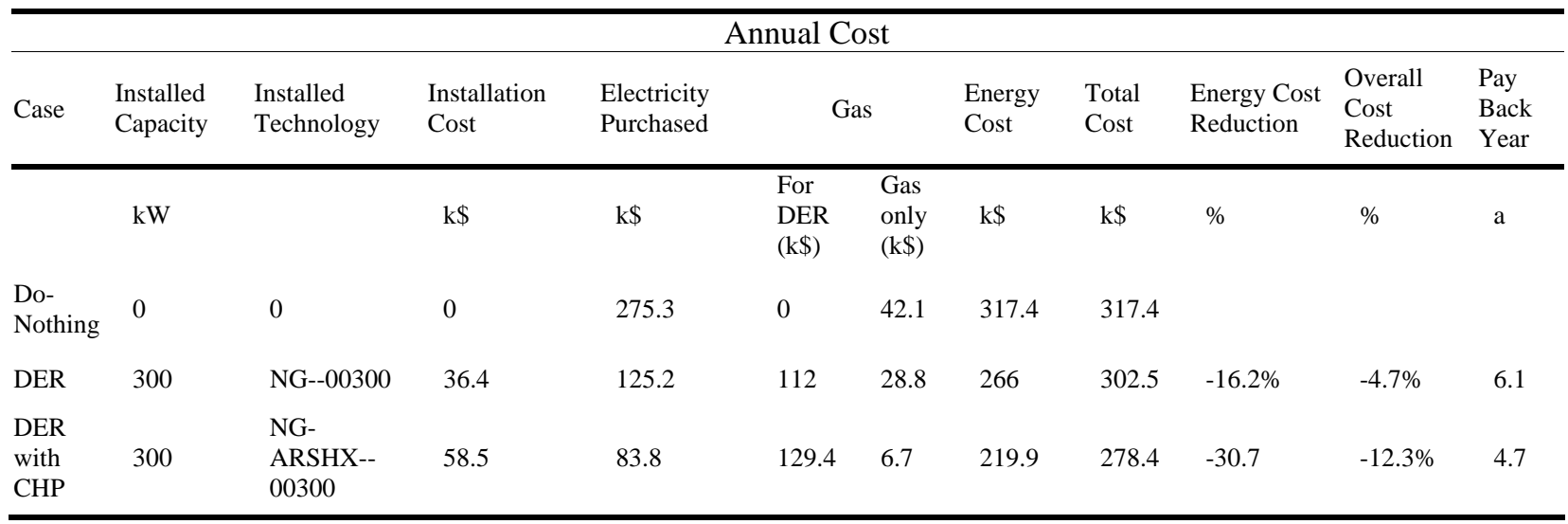

Figure 23 and Figure 24 show how the CHP system meets electricity loads in January. The daytime electricity load is a constant $380 \mathrm{~kW}, 300 \mathrm{~kW}$ of which is met by DER. The remainder $(80 \mathrm{~kW})$ is met by electricity purchase. Figure 25 and Figure 26 show the electricity loads in the summer (July). The electricity load is $569 \mathrm{~kW}, 300 \mathrm{~kW}$ of which is met by DER. The peak cooling electricity load (177 $\mathrm{kW})$ is offset by absorption cooling, and the electricity purchase from the macrogrid is reduced to $198 \mathrm{~kW}$.

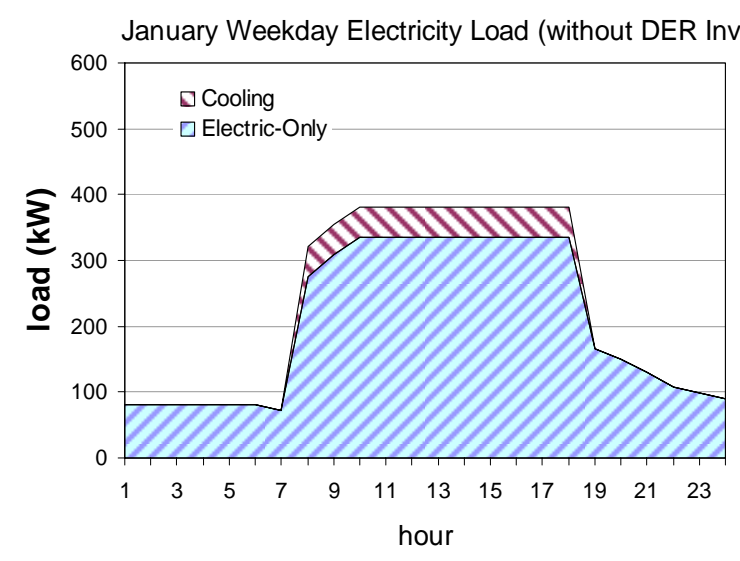

Figure 23: Office Building January Electricity Loads

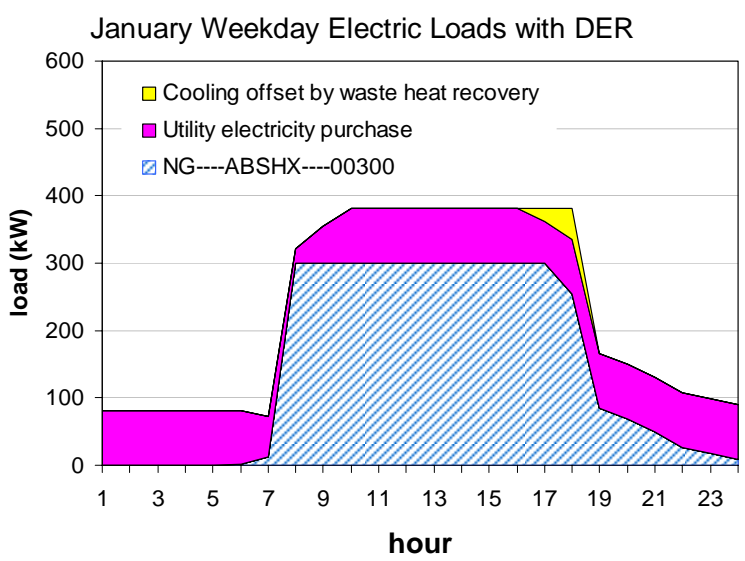

Figure 24: Office Building January Electricity Provisions with CHP System 


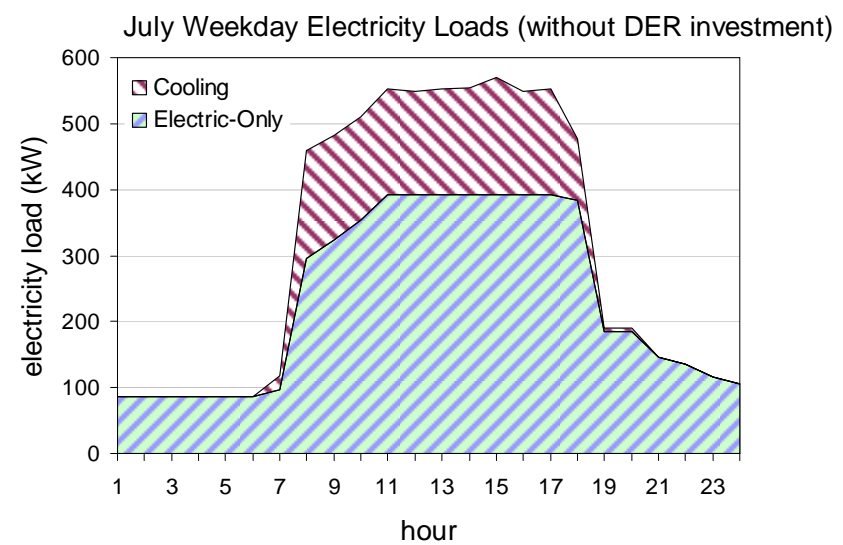

Figure 25: Office Building July Electricity Loads

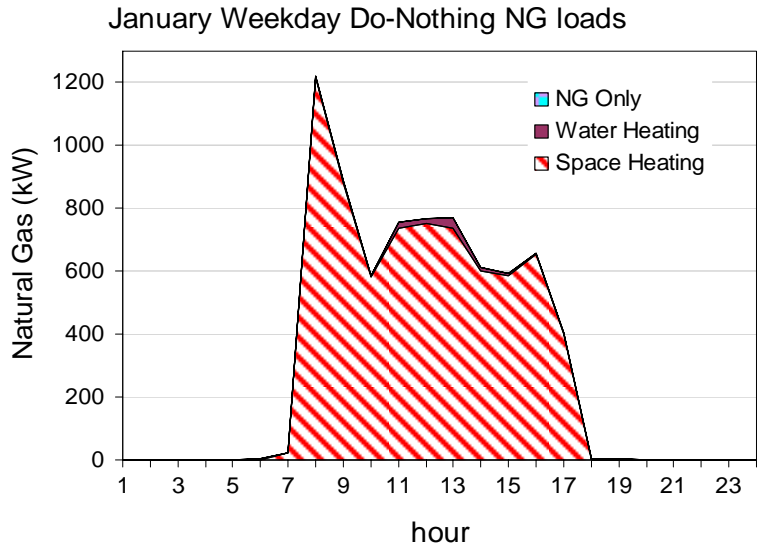

Figure 27: Office Building January Natural Gas Loads

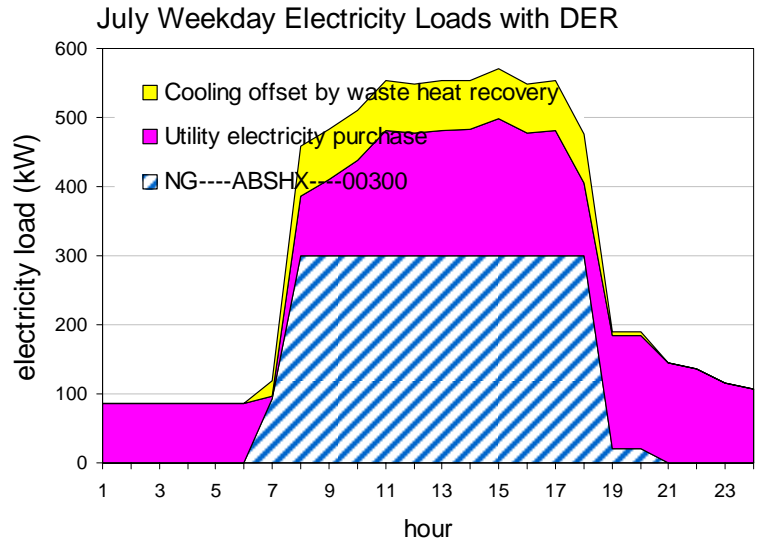

Figure 26: Office Building July Electricity Provision with CHP

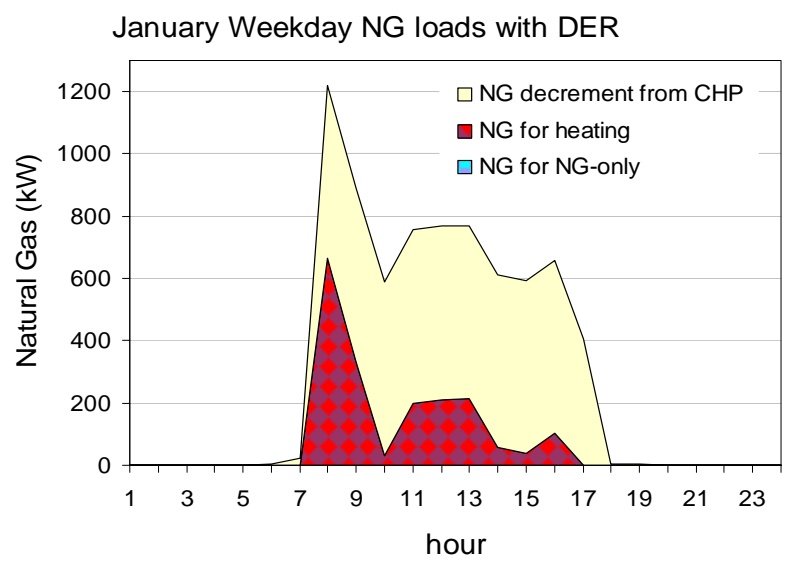

Figure 28: Office Building January Natural Gas Load Provisions with CHP

In addition, Figure 25 and Figure 26 show the January weekday natural gas loads and how they are met by the CHP system.

Furthermore, fuel consumption and carbon emissions resulting from the three scenarios were analyzed (Figure 29, Figure 30, and Table 16). Fuel consumption for DER without CHP is increased by $8 \%$ and carbon emissions are reduced 6.5\%. For the DER with CHP case, fuel consumption is reduced by $8 \%$ and carbon emissions are reduced by $22.7 \%$.

Table 17 states the system efficiency for the three scenarios. In the Do-Nothing scenario, the total efficiency is $42.1 \%$. For DER without CHP, the system efficiency is 31\%, even lower than macrogrid efficiency. For DER with CHP, system efficiency reaches 63.1\%. DER without CHP does not seem to be appropriate for office building 

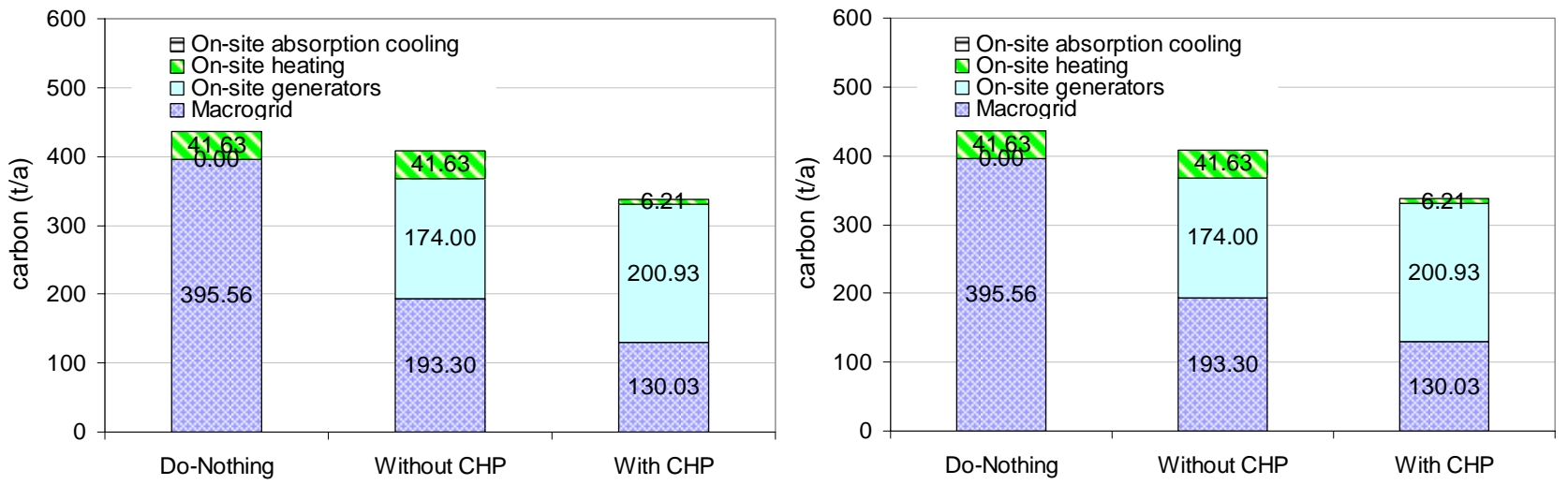

Figure 29: Office Building Annual Carbon Emissions for the Three DER-CAM Scenarios

Figure 30: Office Building Annual Fuel Consumption for the Three DER-CAM Scenarios

Table 16: Office Building Annual Carbon Emissions and Fuel Consumption

\begin{tabular}{ccccc}
\hline Case & $\begin{array}{c}\text { Fuel } \\
\text { Consumption } \\
(\mathrm{TJ} / \mathrm{a})\end{array}$ & $\begin{array}{c}\text { Reduction from } \\
\text { Do-Nothing case }\end{array}$ & $\begin{array}{c}\text { Carbon } \\
\text { Emission } \\
(\mathrm{t} / \mathrm{a})\end{array}$ & $\begin{array}{c}\text { Reduction from } \\
\text { Do-Nothing case }\end{array}$ \\
\hline Do-Nothing & 24.8 & & 437 & $-6.5 \%$ \\
\hline DER & 26.7 & $8 \%$ & 409 & $-22.7 \%$ \\
\hline DER with CHP & 22.7 & $-8.2 \%$ & 338 & \\
\hline
\end{tabular}

Table 17: Office Building System Efficiency

\begin{tabular}{lc}
\hline Macrogrid Electrical Efficiency & $36.6 \%$ \\
Natural Gas to Heat Efficiency & $80 \%$ \\
Do-Nothing System Efficiency & $42.1 \%$ \\
& \\
DER Electrical Efficiency & $31 \%$ \\
DER with CHP System Efficiency & $75 \%$ \\
DER with CHP System Efficiency (FERC) & $53 \%$ \\
Whole System (DER \& Util.) Efficiency & $63.1 \%$ \\
\hline
\end{tabular}




\subsubsection{Hospital}

Table 18 shows the results for the hospital: for the Do-Nothing scenario, the total cost is \$332,920. For DER without CHP, no equipment was selected: there is no change in cost or efficiency from the Do-Nothing case. For DER with CHP, a $300 \mathrm{~kW}$ natural gas engine with heat recovery for heating and absorption cooling was chosen. Compared with the Do-Nothing case, the total annual energy savings are $21.1 \%(\$ 70,310)$ with a payback period of 3.4 years. The annual fuel costs are reduced by $40 \%$. Figure 32 shows the January electricity loads and how the CHP system meets these loads. The winter (January) daytime electricity load is $270 \mathrm{~kW}$, all of which is met by DER. Figure 33 and Figure 34 show the electricity loads in summer (July). The electricity load at 10 A.M. is $311 \mathrm{~kW} ; 300 \mathrm{~kW}$ is met by DER and $44 \mathrm{~kW}$ of the peak cooling electricity load (161 kW) is offset by absorption cooling, reducing the macrogrid electricity purchase to only $128 \mathrm{~kW}$. Figure 35 and Figure 36 show the gas load the natural gas loads for winter (January) - the peak load is $1252 \mathrm{~kW}$, of which $438 \mathrm{~kW}$ is met by the CHP system.

Fuel consumption and carbon emissions were analyzed Figure 37, Figure 38, and Table 19), Fuel consumption for DER with CHP is reduced by $16.6 \%$ and carbon emissions are reduced by $32.4 \%$.

Table 20 shows the system efficiencies. In the Do-Nothing scenario, the total efficiency is $49.5 \%$. For the DER with CHP scenario, the CHP system efficiency is $74.1 \%$ and the total system efficiency (including electricity purchase) is $72.2 \%$.

\section{Table 18: Hospital Building DER-CAM Results}

\begin{tabular}{|c|c|c|c|c|c|c|c|c|c|c|c|}
\hline \multicolumn{12}{|c|}{ Annual Cost } \\
\hline \multirow[t]{2}{*}{ Case } & Installed & Installed & Installation & Electricity & \multicolumn{2}{|c|}{ Gas } & Energy & Total & Energy Cost & Overall Cost & Pay Back \\
\hline & $\mathrm{kW}$ & & $\mathrm{k} \$$ & $\mathrm{k} \$$ & $\begin{array}{l}\text { For } \\
\text { DER } \\
(\mathrm{k} \$)\end{array}$ & $\begin{array}{l}\text { Gas } \\
\text { only } \\
(\mathrm{k} \$)\end{array}$ & $\mathrm{k} \$$ & $\mathrm{k} \$$ & $\%$ & $\%$ & $\mathrm{a}$ \\
\hline $\begin{array}{l}\text { Do- } \\
\text { Nothing }\end{array}$ & 0 & 0 & 0 & 229.9 & 0 & 103.1 & 332.9 & 332.9 & & & \\
\hline DER & 0 & 0 & 0 & 229.9 & 0 & 103.1 & 332.9 & 332.9 & & & \\
\hline $\begin{array}{l}\text { DER } \\
\text { with } \\
\text { CHP }\end{array}$ & 300 & $\begin{array}{l}\text { NG- } \\
\text { ARSHX-- } \\
00300\end{array}$ & 62.9 & 18.6 & 163 & 18 & 199.7 & 262.6 & $-40.01 \%$ & $-21.1 \%$ & 3.4 \\
\hline
\end{tabular}


The Potential for Distributed Generation in Japanese Prototype Buildings: English Version

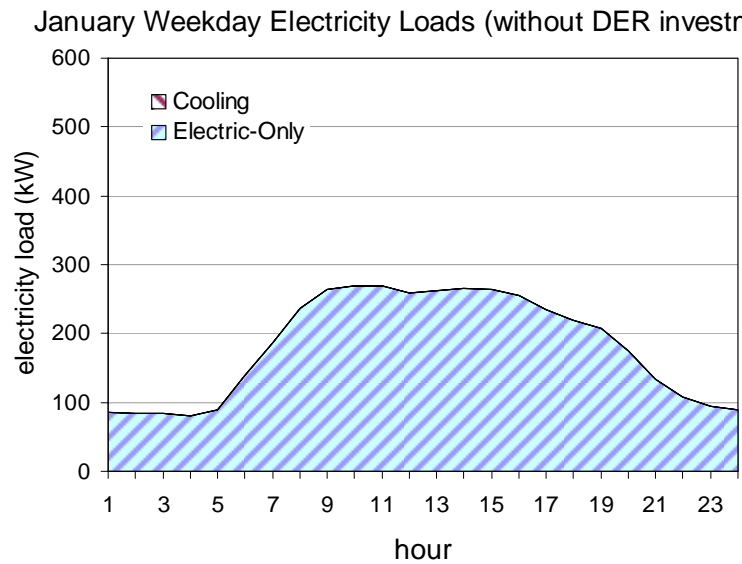

Figure 31: Hospital January Electricity Load

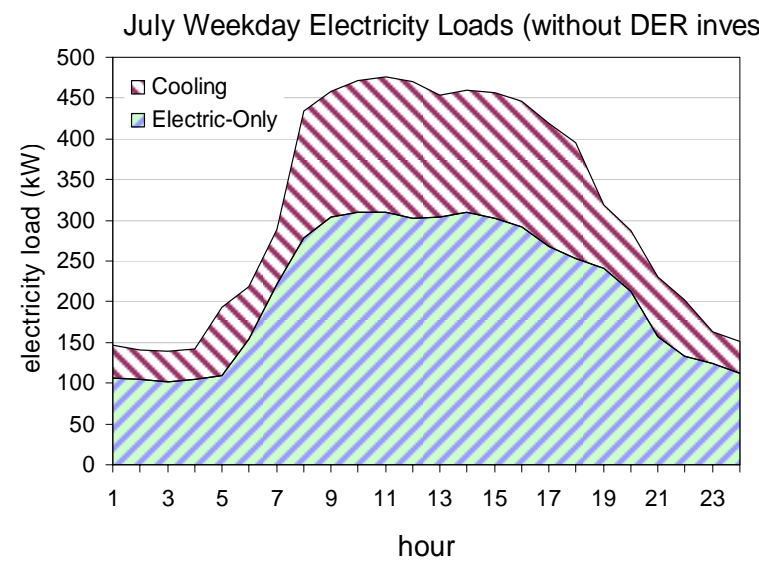

Figure 33: Hospital July Electricity Load

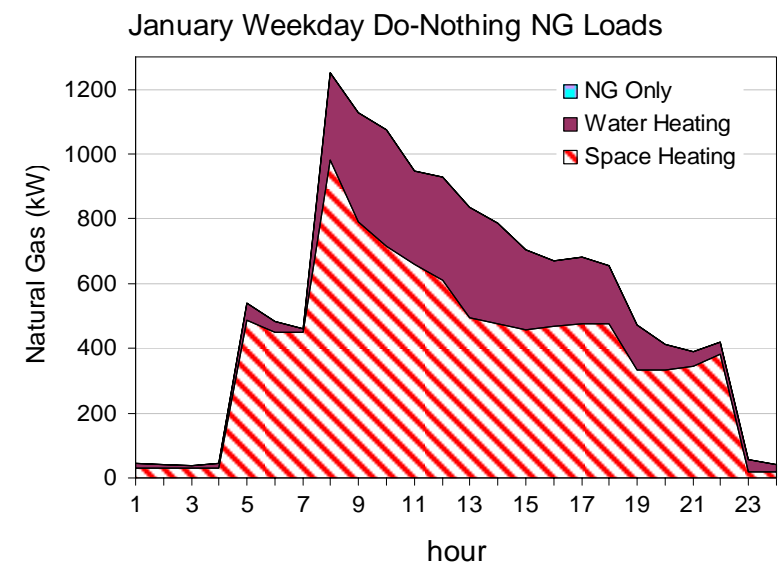

Figure 35: Hospital January Natural Gas Load

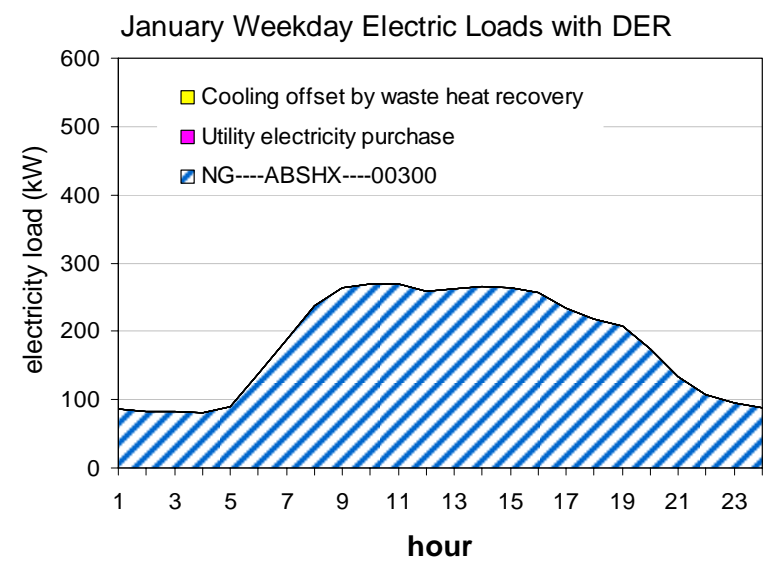

Figure 32: Hospital January Electricity Load Provision with CHP

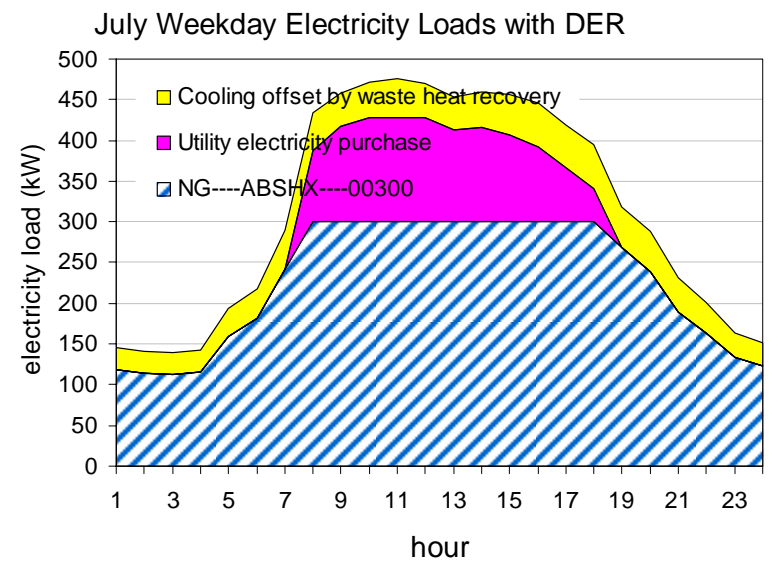

Figure 34: Hospital July Electricity Load Provision with CHP

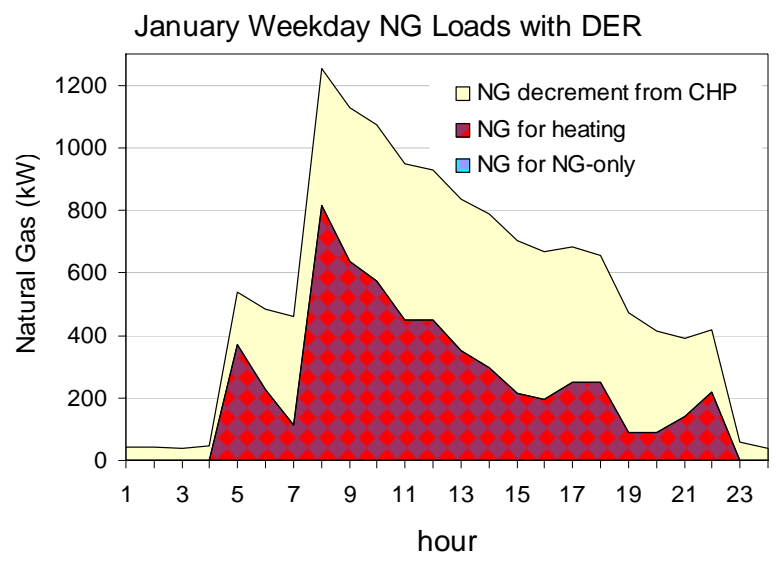

Figure 36: Hospital January Natural Gas Load Provision with CHP 


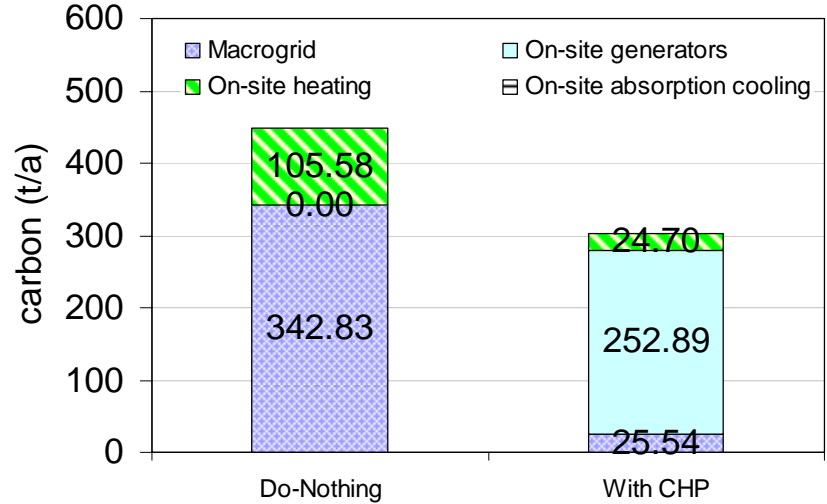

Figure 37: Hospital Annual Carbon Emissions

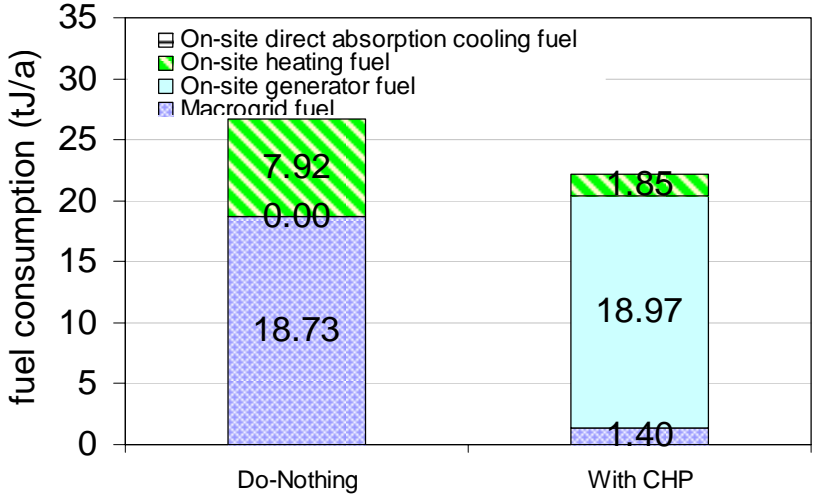

Figure 38: Hospital Annual Fuel Consumption

Table 19: Hospital Annual Carbon Emissions and Fuel Consumption

\begin{tabular}{ccccc}
\hline Case & $\begin{array}{c}\text { Fuel } \\
\text { Consumption } \\
(\mathrm{TJ} / \mathrm{a})\end{array}$ & $\begin{array}{c}\text { Reduction from } \\
\text { Do-Nothing case }\end{array}$ & $\begin{array}{c}\text { Carbon } \\
\text { Emission } \\
(\mathrm{t} / \mathrm{a})\end{array}$ & $\begin{array}{c}\text { Reduction from } \\
\text { Do-Nothing case }\end{array}$ \\
\hline Do-Nothing & 26.7 & & 448 & \\
\hline DER & & & & $-32.4 \%$ \\
\hline CHP & 22.2 & $-16.6 \%$ & 303 & \\
\hline
\end{tabular}

Table 20: Hospital System Efficiencies

Macrogrid Electrical Efficiency

Natural Gas to Heat Efficiency

Do-Nothing System Efficiency

DER Electrical Efficiency

DER with CHP System Efficiency

DER with CHP System Efficiency (FERC)

Whole System (DER \& Util.) Efficiency
$74.1 \%$

$36.6 \%$

$80 \%$

$49.5 \%$

$52.5 \%$

$72.2 \%$

\subsubsection{Hotel}

Table 21 shows the results for the hotel. For the Do-Nothing scenario, the total annual energy bill is $\$ 374,580$. For DER without CHP, a $30 \mathrm{~kW}$ natural gas engine was selected; electricity purchase decreases, gas consumption increases, and the total annual fuel costs are reduced by $10 \%$. The total annual energy savings (including the cost of capital and maintenance) are $9 \quad(\$ 33,470)$. The payback period is less than 1 year, because of the small capacity of the DER selected. Most energy is purchased from the macrogrid. The impact of DG without CHP is limited. 
Table 21: Hotel DER-CAM Results

\begin{tabular}{|c|c|c|c|c|c|c|c|c|c|c|c|}
\hline \multicolumn{12}{|c|}{ Annual Cost } \\
\hline Case & $\begin{array}{l}\text { Installed } \\
\text { Capacity }\end{array}$ & $\begin{array}{l}\text { Installed } \\
\text { Technology }\end{array}$ & $\begin{array}{c}\text { Installation } \\
\text { Cost }\end{array}$ & $\begin{array}{l}\text { Electricity } \\
\text { Purchased }\end{array}$ & & & $\begin{array}{l}\text { Energy } \\
\text { Cost }\end{array}$ & $\begin{array}{l}\text { Total } \\
\text { Cost }\end{array}$ & $\begin{array}{c}\text { Energy } \\
\text { Cost } \\
\text { Reduction }\end{array}$ & $\begin{array}{c}\text { Overall } \\
\text { Cost } \\
\text { Reduction }\end{array}$ & $\begin{array}{l}\text { Pay } \\
\text { Back } \\
\text { Year }\end{array}$ \\
\hline & $\mathrm{kW}$ & & $\mathrm{k} \$$ & $\mathrm{k} \$$ & $\begin{array}{l}\text { For } \\
\text { DER } \\
(\mathrm{k} \$)\end{array}$ & $\begin{array}{l}\text { Gas } \\
\text { only } \\
\text { (k\$) }\end{array}$ & $\mathrm{k} \$$ & $\mathrm{k} \$$ & $\%$ & $\%$ & $\mathrm{a}$ \\
\hline $\begin{array}{l}\text { Do- } \\
\text { Nothin } \\
\text { g }\end{array}$ & 0 & 0 & 0 & 268.9 & 0 & 105.7 & 374.6 & 374.6 & & & \\
\hline DER & 30 & $\begin{array}{l}\text { NG-- } \\
0030\end{array}$ & 3.5 & 260.8 & 4.2 & 72.5 & 337.5 & 341.0 & $-9.9 \%$ & $-9 \%$ & 0.8 \\
\hline $\begin{array}{l}\text { DER } \\
\text { with } \\
\text { CHP }\end{array}$ & 300 & $\begin{array}{l}\text { NG- } \\
\text { ARSHX- } \\
-00300\end{array}$ & 66.3 & 24.9 & 189.1 & 9.5 & 223.5 & 289.8 & $-40.3 \%$ & $-22.6 \%$ & 3.0 \\
\hline
\end{tabular}

For the DER with CHP scenario, a $300 \mathrm{~kW}$ natural gas engine with heat recovery for heating and absorption cooling was chosen. Compared with the Do-Nothing scenario, the total annual energy savings are $21.6 \%(\$ 84,760)$ with a payback period of 3 years. The total annual fuel costs are reduced by $40.3 \%$. Figure 39 and Figure 40 show how the CHP system meets electricity load. In the winter (January) the day time peak electricity load is $278 \mathrm{~kW}$ at 12 P.M. The entire load is met by the CHP system. Figure 41 and Figure 42 shows the case in the summer. The peak electricity load is $321 \mathrm{~kW}$ at 2 P.M. $300 \mathrm{~kW}$ of this is met by the CHP system and $72 \mathrm{~kW}$ of the $174 \mathrm{~kW}$ peak cooling load is offset by absorption cooling, and the electricity purchase from the macrogrid is reduced to $123 \mathrm{~kW}$.

Figure 43 and Figure 44 show the gas load. $480 \mathrm{~kW}$ of the peak winter load is met by the CHP system and $179 \mathrm{~kW}$ are provided by natural gas purchase. Fuel consumption and carbon emissions of CHP system were analyzed (Figure 45, Figure 46, and Table 22 ). No difference is seen in the DER without CHP scenario. Fuel consumption for DER with CHP is reduced by $18.7 \%$ and carbon emissions are reduced by $34.3 \%$.

Table 23 shows the system efficiency. For the Do- nothing scenario, the total efficiency is $48.3 \%$. For the DER without CHP scenario, the total system efficiency (including macrogrid electricity purchase) is $27.5 \%$. For the DER with CHP scenario, the CHP system efficiency is $78 \%$ and the total system efficiency (including macrogrid electricity purchase) is $75 \%$. The total system efficiency using the FERC definition is 54.5\%. 
The Potential for Distributed Generation in Japanese Prototype Buildings: English Version

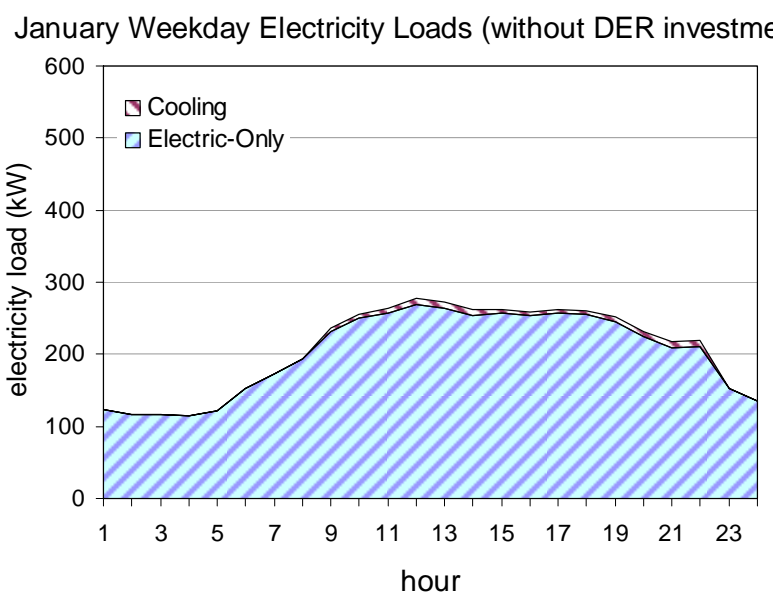

Figure 39: Hotel January Electricity Loads

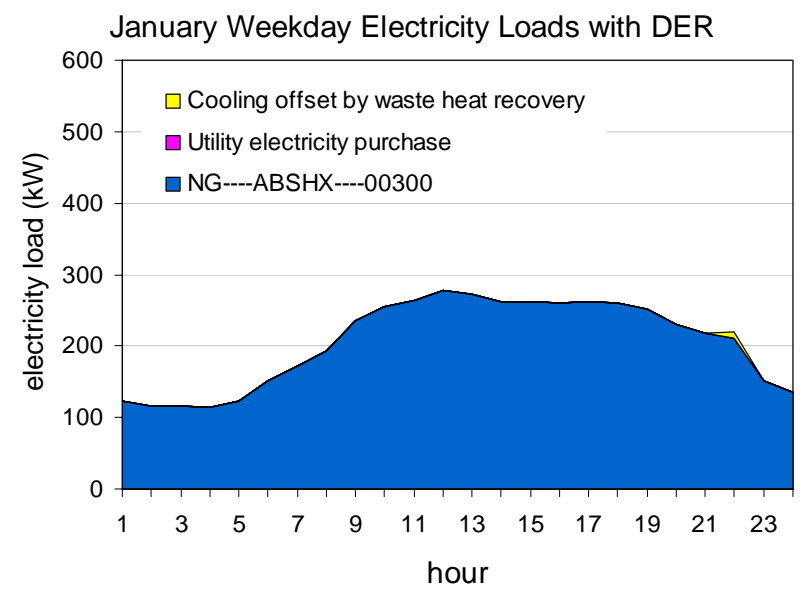

Figure 40: Hotel January Electricity Load Provision

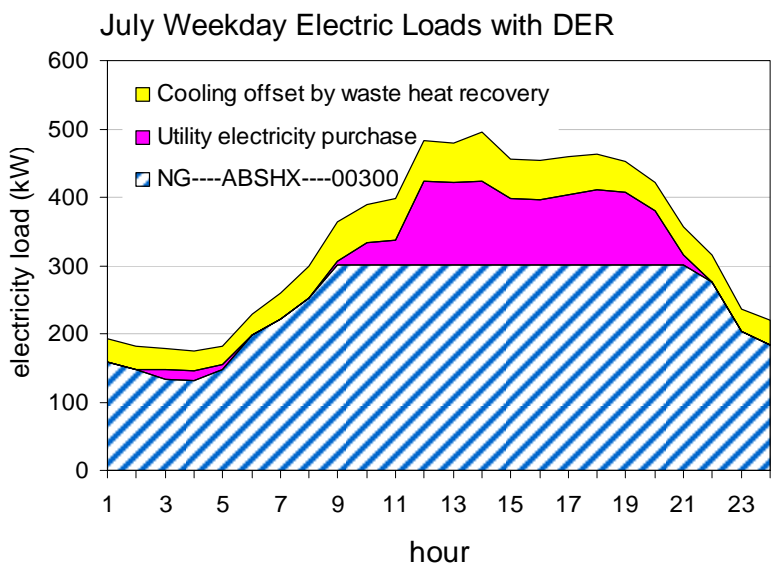

Figure 42: Hotel July Electricity Load Provision with CHP

January Weekday NG loads with DER

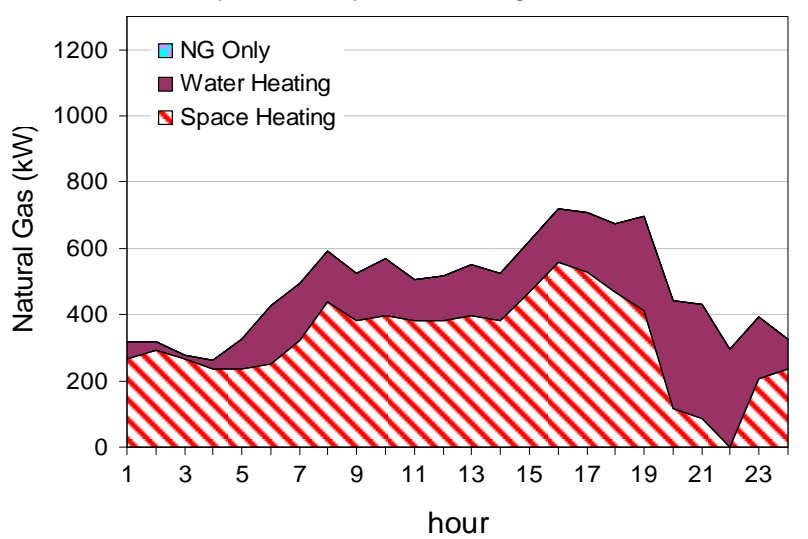

Figure 43: Hotel January Natural Gas Loads
Figure 44: Hotel January Natural Gas Load Provisions with CHP 


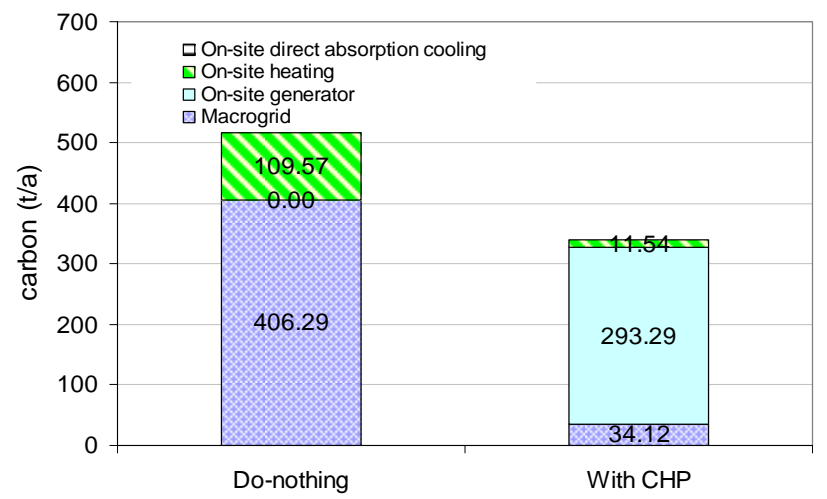

Figure 45: Hotel Annual Carbon Emissions

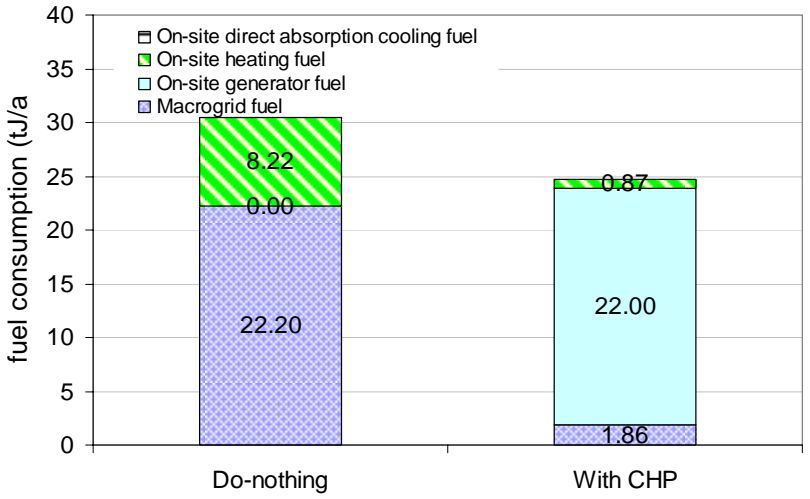

Figure 46: Hotel Annual Fuel Consumption

Table 22: Hotel Annual Carbon Emissions and Fuel Consumption

\begin{tabular}{ccccc}
\hline Case & $\begin{array}{c}\text { Fuel } \\
\text { Consumption } \\
(\mathrm{TJ} / \mathrm{a})\end{array}$ & $\begin{array}{c}\text { Reduction from } \\
\text { Do-Nothing case }\end{array}$ & $\begin{array}{c}\text { Carbon Emission } \\
(\mathrm{t} / \mathrm{a})\end{array}$ & $\begin{array}{c}\text { Reduction from } \\
\text { Do-Nothing case }\end{array}$ \\
\hline Do-Nothing & 30.4 & & 516 & \\
\hline DER & 30.5 & 0 & 516 & 0 \\
\hline DER with CHP & 24.7 & $-18.7 \%$ & 339 & $-34.3 \%$ \\
\hline
\end{tabular}

Table 23: Hotel System Efficiencies

Macrogrid Electrical Efficiency

Natural Gas to Heat Efficiency

Do-Nothing System Efficiency

DER Electrical Efficiency

DER with CHP System Efficiency

DER with CHP System Efficiency (FERC)

Whole System (DER \& Util.) Efficiency
$36.6 \%$

$80 \%$

$48.3 \%$

$27.5 \%$

$78 \%$

$54.5 \%$

$75 \%$ 


\subsubsection{Retail}

Table 24 shows the results for the retail building: For the Do-Nothing scenario, the total cost is $\$ 386,590$. For the DER without CHP scenario, a 1,000 kW natural gas engine is selected; annual fuel costs are reduced by $32 \%$ and the total annual energy cost (including capital and maintenance costs) are reduced by $8.6 \%(\$ 33,410)$. The payback period is less than 6 year.

For DER with CHP, a 1,000 kW natural gas engine with heat recovery for heating and absorption cooling was chosen. Relative to the Do-Nothing scenario, the savings are $11.4 \%(\$ 44,000)$ with a payback period of 7 years. The total annual fuel costs are reduced by $44.2 \%$.

Figure 47 and Figure 48 show the January electricity loads and how the CHP system meets these loads. The winter (January) daytime peak electricity load is $471 \mathrm{~kW}$ at 2 P.M., all of which is met by the CHP system. Figure 49 and Figure 50 show this for the summer (July). The summer peak electricity load is $639 \mathrm{~kW}$ at 2 P.M., all of which is met by the CHP system. $118 \mathrm{~kW}$ of the $253 \mathrm{~kW}$ peak cooling electricity load is offset by absorption cooling. No electricity is purchased from the grid.

Figure 51 and Figure 52 show the natural gas load. The winter (January) peak natural gas load is $920 \mathrm{~kW}$ at 9 A.M., of which $380 \mathrm{~kW}$ is met by the CHP system. During the daytime, natural gas loads, which range from $335 \mathrm{~kW}$ to $591 \mathrm{~kW}$, are almost all met by the CHP system.

Fuel consumption and carbon emissions were analyzed (Figure 53, Figure 54, and Table 25). For the DER system without CHP, fuel consumption is reduced by $7 \%$ and the carbon emissions by $19.9 \%$. For the DER system with CHP, fuel consumption is reduced by $12.5 \%$ and carbon emission by $34.4 \%$.

Table 26 shows the system efficiencies. For the Do-Nothing case, the total efficiency is $41.2 \%$. For DER without CHP, the total system efficiency (including electricity purchase) is 34\%. For DER with CHP, the system efficiency is $69.4 \%$ and the total system efficiency (including electricity purchase) is 69.4\%. Total FERC system efficiency is 51.7 .

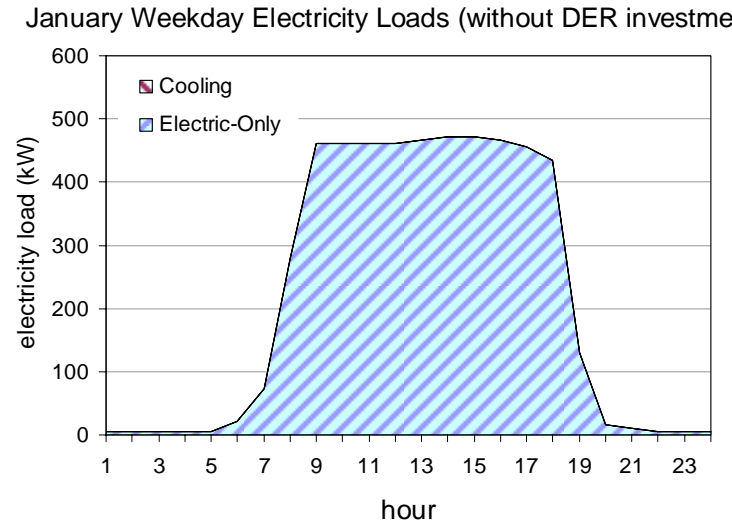

Figure 47: Retail January Weekday Electricity Loads

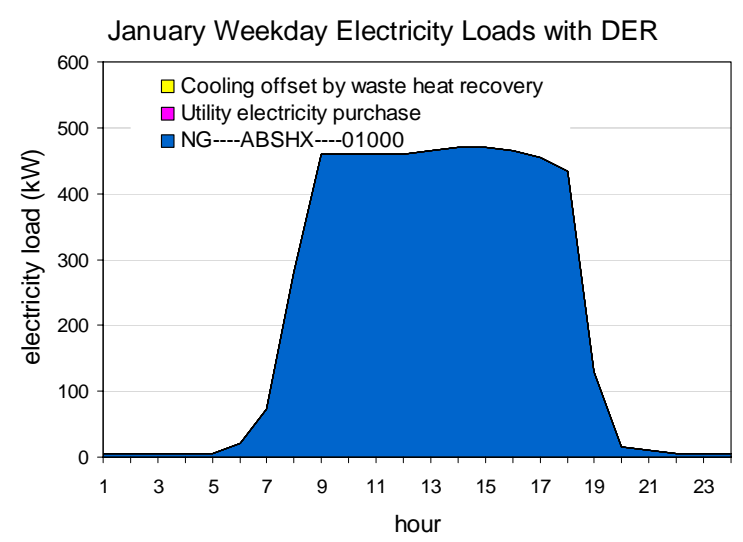

Figure 48: Retail January Weekday Electricity Load Provision 
Table 24: Retail DER-CAM Results

\begin{tabular}{|c|c|c|c|c|c|c|c|c|c|c|c|}
\hline \multicolumn{12}{|c|}{ Annual Cost } \\
\hline Case & $\begin{array}{l}\text { Installed } \\
\text { Capacity }\end{array}$ & $\begin{array}{l}\text { Installed } \\
\text { Technology }\end{array}$ & $\begin{array}{c}\text { Installation } \\
\text { Cost }\end{array}$ & $\begin{array}{l}\text { Electricity } \\
\text { Purchased }\end{array}$ & & & $\begin{array}{l}\text { Energy } \\
\text { Cost }\end{array}$ & $\begin{array}{l}\text { Total } \\
\text { Cost }\end{array}$ & $\begin{array}{c}\text { Energy } \\
\text { Cost } \\
\text { Reduction }\end{array}$ & $\begin{array}{c}\text { Overall } \\
\text { Cost } \\
\text { Reduction }\end{array}$ & $\begin{array}{l}\text { Pay } \\
\text { Back } \\
\text { Year }\end{array}$ \\
\hline & $\mathrm{kW}$ & & $\mathrm{k} \$$ & $\mathrm{k} \$$ & $\begin{array}{l}\text { For } \\
\text { DER } \\
(\mathrm{k} \$)\end{array}$ & $\begin{array}{l}\text { Gas } \\
\text { only } \\
\text { (k\$) }\end{array}$ & $\mathrm{k} \$$ & $\mathrm{k} \$$ & $\%$ & $\%$ & $\mathrm{a}$ \\
\hline $\begin{array}{l}\text { Do- } \\
\text { Nothin } \\
\text { g }\end{array}$ & 0 & 0 & 0 & 347.1 & 0 & 39.5 & 386.6 & 386.6 & & & \\
\hline DER & 1000 & $\begin{array}{l}\text { NG-- } \\
01000\end{array}$ & 90.3 & 0 & 235.3 & 27.6 & 262.9 & 353.2 & $-32 \%$ & $-8.6 \%$ & 5.8 \\
\hline $\begin{array}{l}\text { DER } \\
\text { with } \\
\text { CHP }\end{array}$ & 1000 & $\begin{array}{c}\text { NG- } \\
\text { ARSHX-- } \\
01000\end{array}$ & 126.7 & 0 & 212.3 & 3.4 & 215.7 & 342.6 & $-44.2 \%$ & $-11.4 \%$ & 6.8 \\
\hline
\end{tabular}

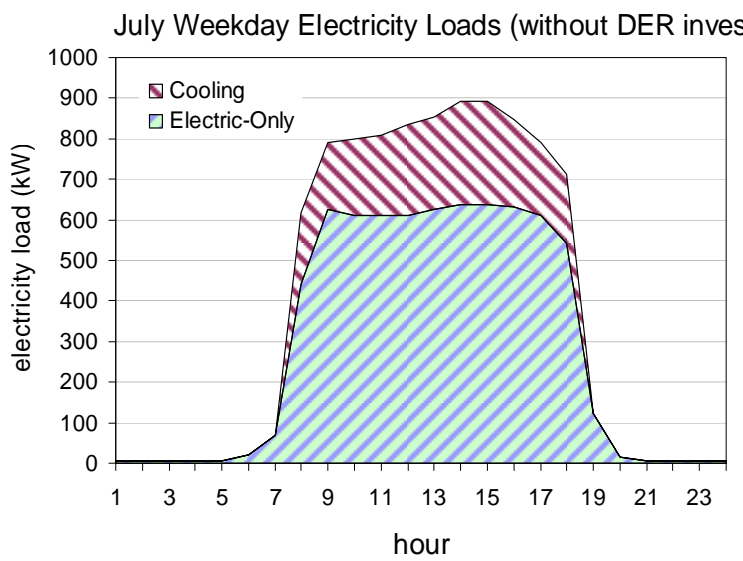

Figure 49: Retail July Weekday Electricity Loads

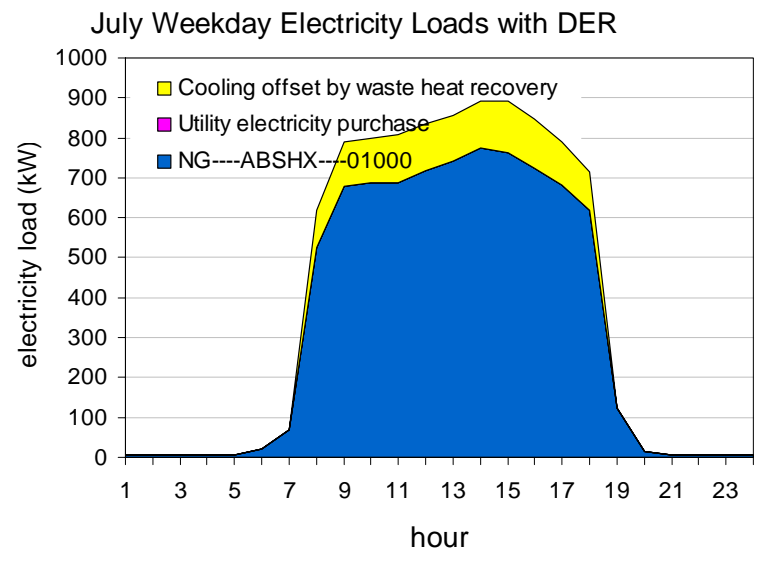

Figure 50: Retail July Weekday Electricity Load Provision with CHP

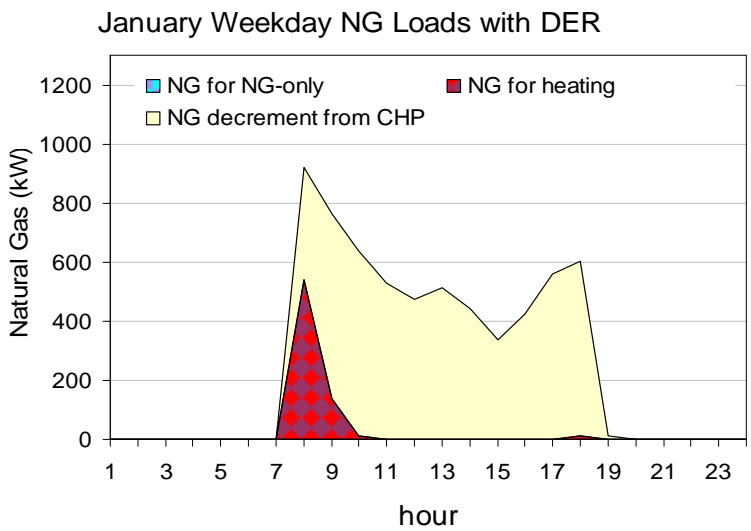

Figure 52: Retail January Weekday Natural Gas Load Provision with CHP 


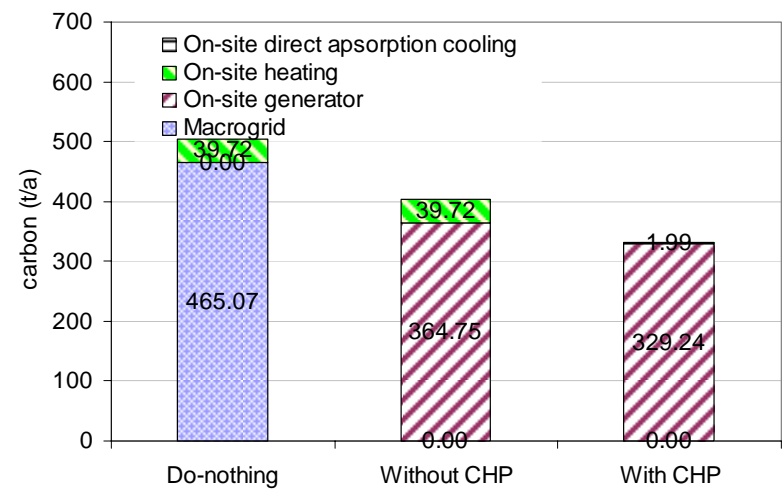

Figure 53: Retail Annual Carbon Emissions

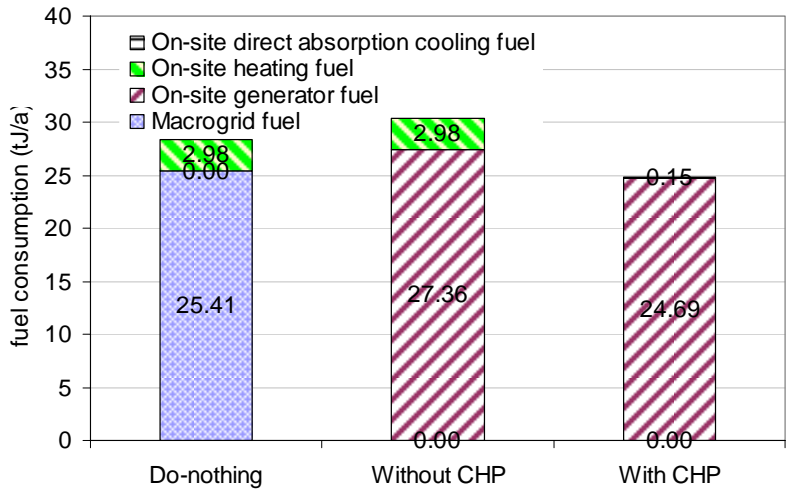

Figure 54: Retail Annual Fuel Consumption

Table 25: Retail Annual Carbon Emissions and Fuel Consumption

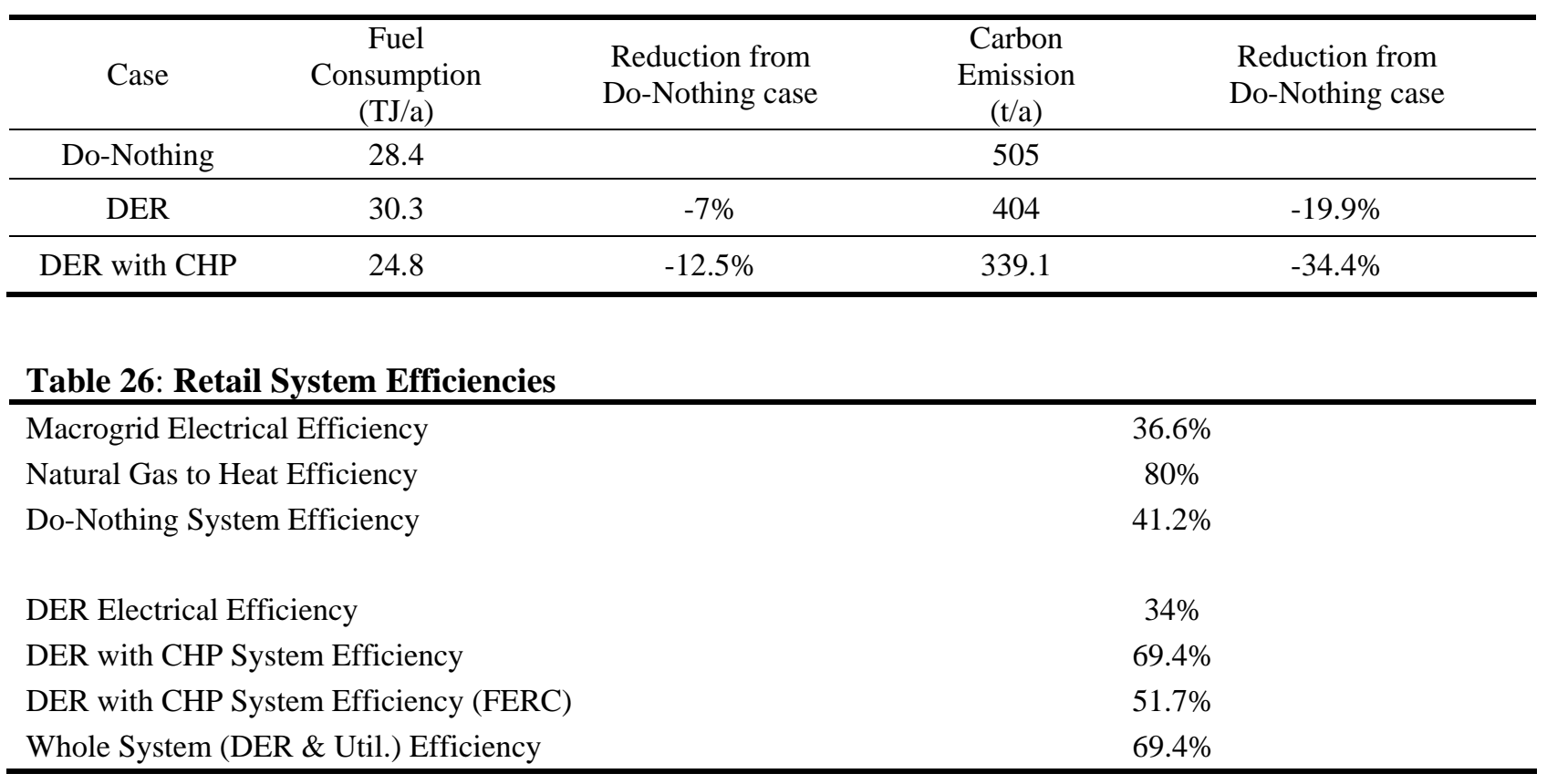




\subsubsection{Sports Facility}

Sports facility includes pool, tennis court, gym etc...Table 27 shows the DER-CAM results for the sports facility. For the Do-Nothing scenario, the total cost is $\$ 988,140$. For DG without CHP a 30 $\mathrm{kW}$ natural gas engine was selected; annual fuel costs are reduced by $20.89 \%$ and total annual energy costs (including the capital and maintenance costs) are reduced by $20.6 \%(\$ 205,200)$. The payback period is less than 3 months.

For the DER with CHP scenario, two $300 \mathrm{~kW}$ natural gas engines with heat recovery for heating were selected. Compared with the Do-Nothing case, the total annual energy savings are 32.5\% $(\$ 324,300)$ with a payback period of 3.5 years. The total annual fuel costs are reduced by $42.5 \%$.

Figure 55 and Figure 56 show the winter (January) electricity loads and how the CHP system meets them. The peak winter electricity load is $500 \mathrm{~kW}$ at 2 P.M., all of which is met by CHP. Figure 57 and Figure 58 show this data for the summer. The peak electricity load is $594 \mathrm{~kW}$ at 8 P.M., all of which is met by the CHP system. No electricity is purchased from the macrogrid.

Figure 59 and Figure 60 show the winter (January) natural gas loads and how the CHP system meets them. The winter peak load is $4020 \mathrm{~kW}$ at 9 P.M., of which $860 \mathrm{~kW}$ is met by the CHP system.

Carbon emissions and fuel consumption were analyzed (Figure 61, Figure 62, and Table 28). For the DER without CHP scenario, there is little difference from the Do-Nothing scenario because the installed generator is small. For the DER with CHP scenario, fuel consumption is reduced by $16.4 \%$ and carbon emissions by $26.3 \%$.

Table 29 shows the system efficiency. In the Do-Nothing scenario, the total efficiency is $64.1 \%$. For the DER without CHP scenario, the total DER system efficiency (including electricity purchase) is $27.5 \%$. For the DER with CHP scenario, the CHP system efficiency is $73.6 \%$ and the total system efficiency (including electricity purchase) is 76\%. Total FERC system efficiency is 52.3 .

Table 27: Sports Facility DER-CAM Results

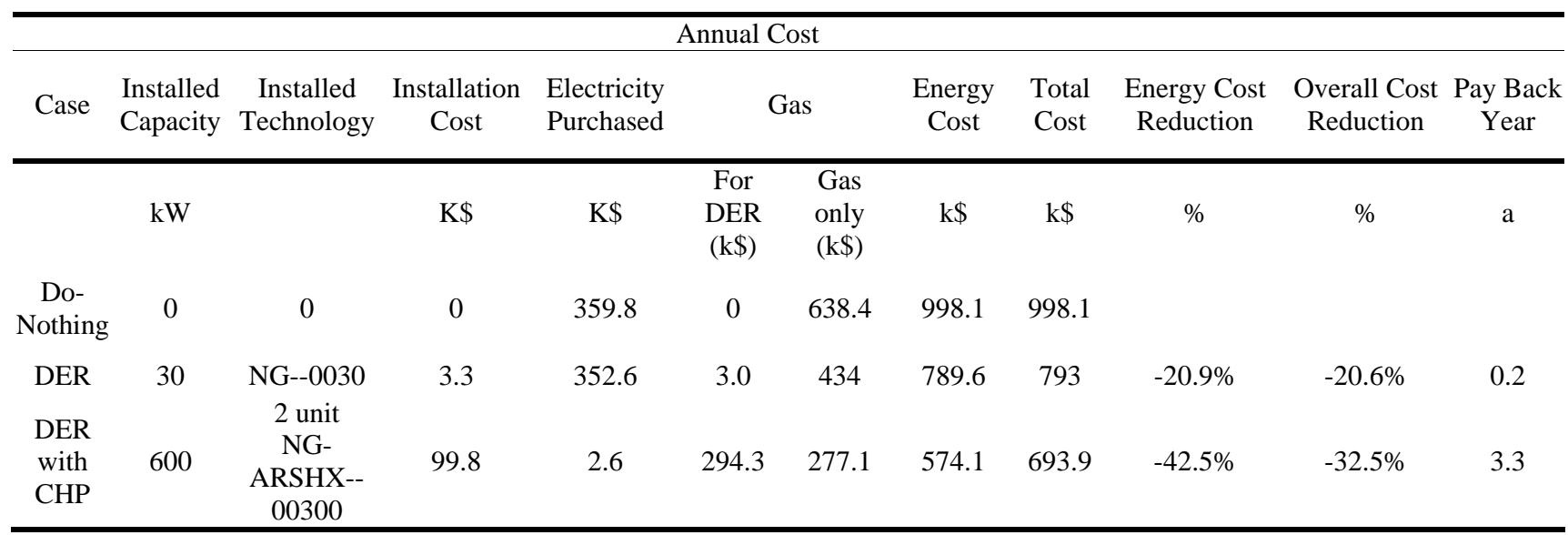




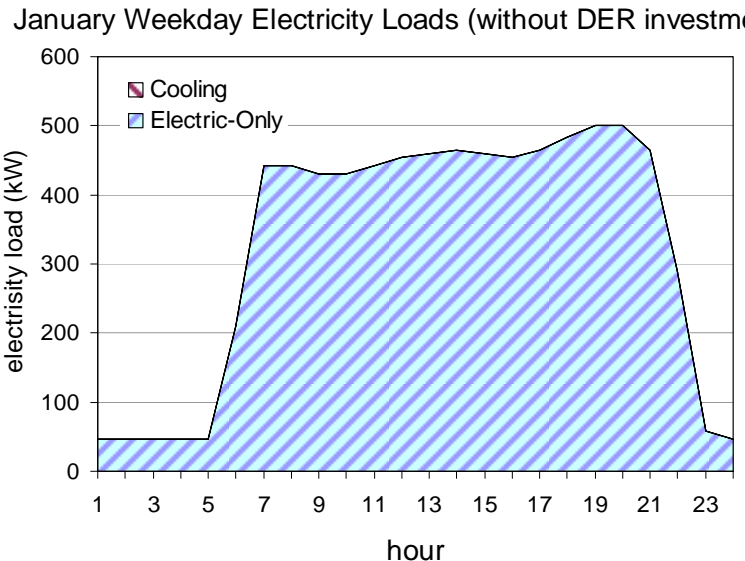

Figure 55: Sports Facility January Electricity Loads

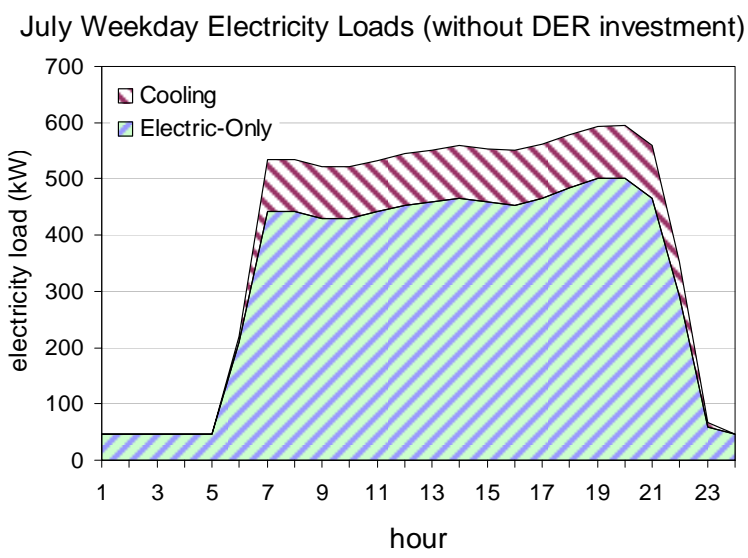

Figure 57: Sports Facility July Electricity Loads

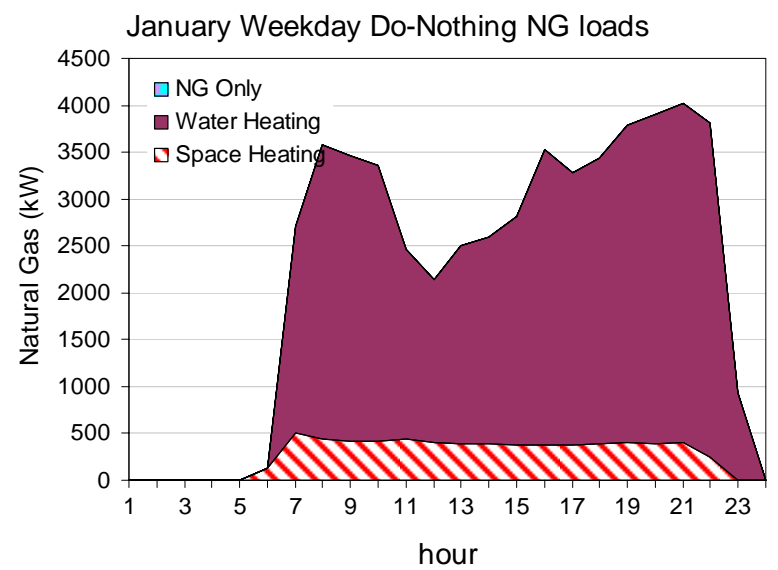

Figure 59: Sports Facility January Natural Gas Loads

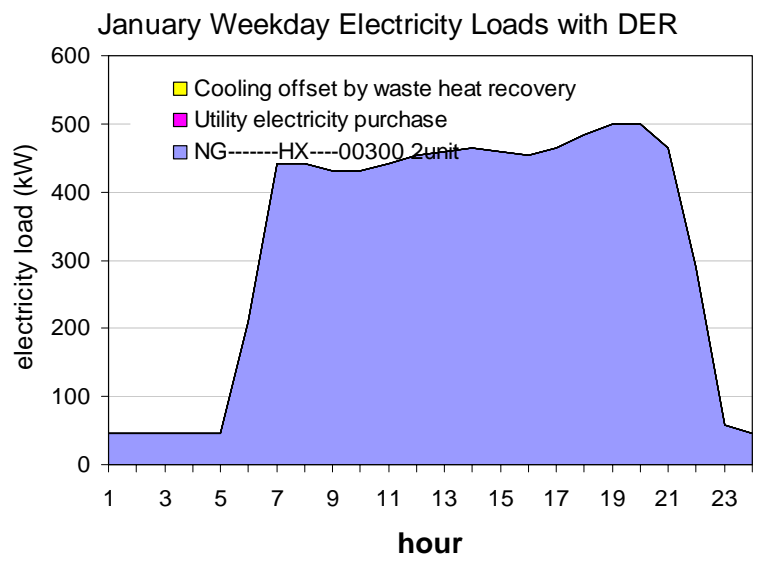

Figure 56: Sports Facility January Electricity Load Provision with CHP

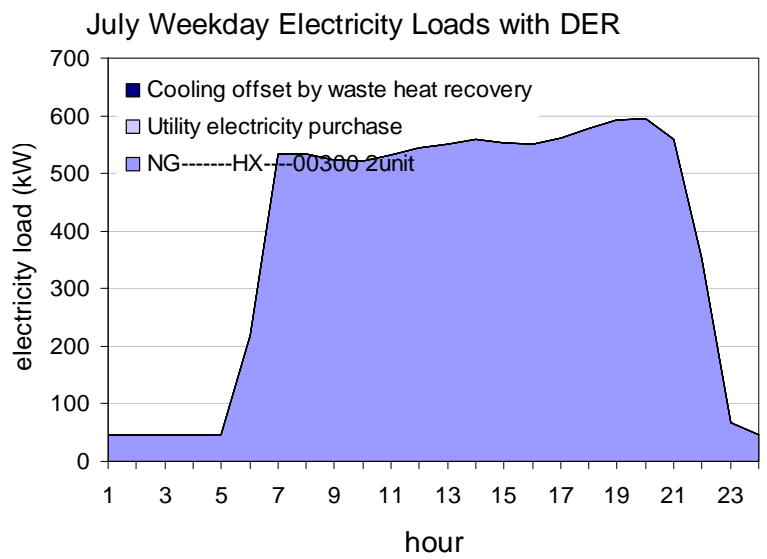

Figure 58: Sports Facility July Electricity Load Provision with CHP

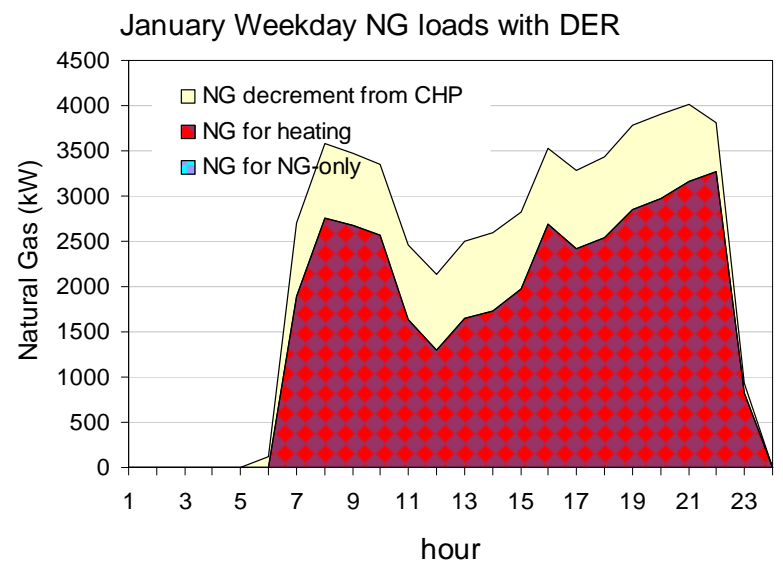

Figure 60: Sports Facility January Natural Gas Load Provision with CHP 


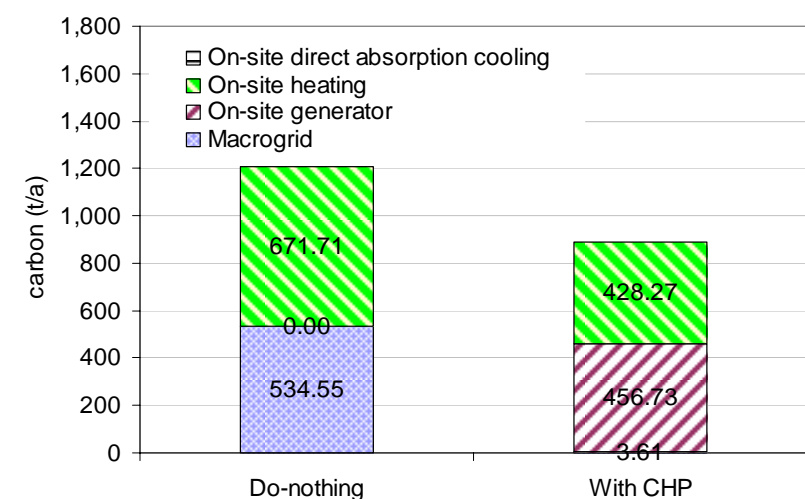

Figure 61: Sports Facility Annual Carbon Emissions

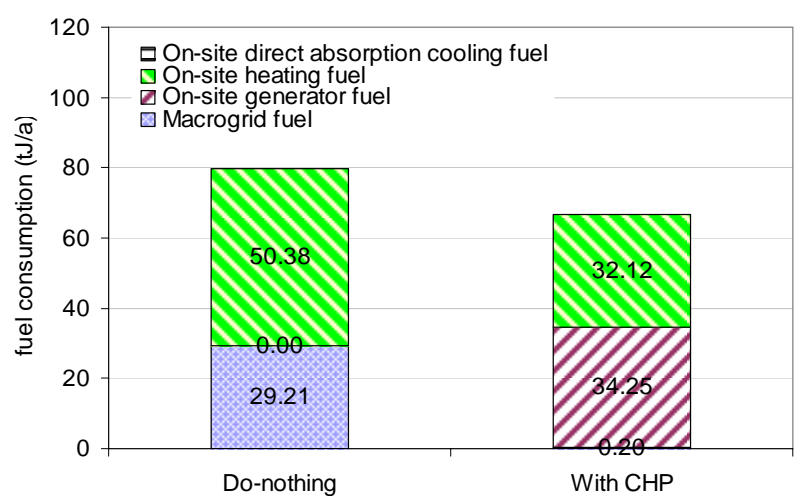

Figure 62: Sports Facility Annual Fuel Consumption

Table 28: Sports Facility Annual Carbon Emissions and Fuel Consumption

\begin{tabular}{ccccc}
\hline Case & $\begin{array}{c}\text { Fuel } \\
\text { Consumption } \\
(\mathrm{TJ} / \mathrm{a})\end{array}$ & $\begin{array}{c}\text { Reduction from } \\
\text { Do-Nothing case }\end{array}$ & $\begin{array}{c}\text { Carbon } \\
\text { Emission } \\
(\mathrm{t} / \mathrm{a})\end{array}$ & $\begin{array}{c}\text { Reduction from } \\
\text { Do-Nothing case }\end{array}$ \\
\hline Do-Nothing & 79.6 & & 1206 & 0 \\
\hline DER & 79.7 & 0 & 1206 & $-26.3 \%$ \\
\hline DER with CHP & 66.6 & $-16.4 \%$ & 889 & \\
\hline
\end{tabular}

Table 29: Sports Facility System Efficiencies

\begin{tabular}{lc}
\hline Macrogrid Electrical Efficiency & $36.6 \%$ \\
Natural Gas to Heat Efficiency & $80 \%$ \\
Do-Nothing System Efficiency & $64.1 \%$ \\
& \\
DER Electrical Efficiency & $27.5 \%$ \\
DER with CHP System Efficiency & $73.6 \%$ \\
DER with CHP System Efficiency (FERC) & $52.3 \%$ \\
Whole System (DER \& Util.) Efficiency & $76.6 \%$ \\
\hline
\end{tabular}




\subsubsection{Conclusions for $10,000 \mathrm{~m}^{2}$ Buildings}

CHP shifts the balance of utility purchase of electricity and natural gas in several ways. Operating generation equipment reduces utility electricity purchase and increases natural gas purchase. Recovered heat from the equipment can be used to offset natural gas used for heating and/or electricity used for cooling. Figure 63 shows the peak load shift effect of CHP in the prototype buildings in both winter and summer. In the winter, the heating peak load of the sports facility is most significant, followed by hospital and office buildings. The biggest peak load reduction is seen in the sports facility (900 kWh), followed by the office building (550 kWh).

In the summer, the retail building shows the biggest utility electricity reduction; all peak loads can be economically met by the generated power and waste heat recovery from CHP. The effect of air conditioning by heat recovery is seen in all of the building except the sports facility. Heat recovery for cooling is not economic for the sports facility.

CHP also shifts the amounts and sources of carbon emissions. Figure 64 shows the carbon emissions reductions. CHP installation reduces these emissions for all of the prototype buildings. This reduction is most significant for the hospital (61.4\% reduction), followed by hotel (34\% reduction) and retail building (34\% reduction).

Furthermore, CHP shifts the amounts and sources of annual energy costs. Figure 65 shows the economics of CHP installation. For the sports facility, costs are reduced by $32 \%$, followed by hotel (23\% reduction) and hospital (21\% reduction). The hotel has the shortest payback period (3.0 years), followed by sports facility (3.3 years) and hospital (3.4 years).

CHP installation benefits the entire prototype buildings considered. Hospitals, hotels, and sports facilities have the potential for benefiting the most. Although benefits are not as great as for other building types, office buildings - which are traditionally not considered DER candidates - can also benefit. 


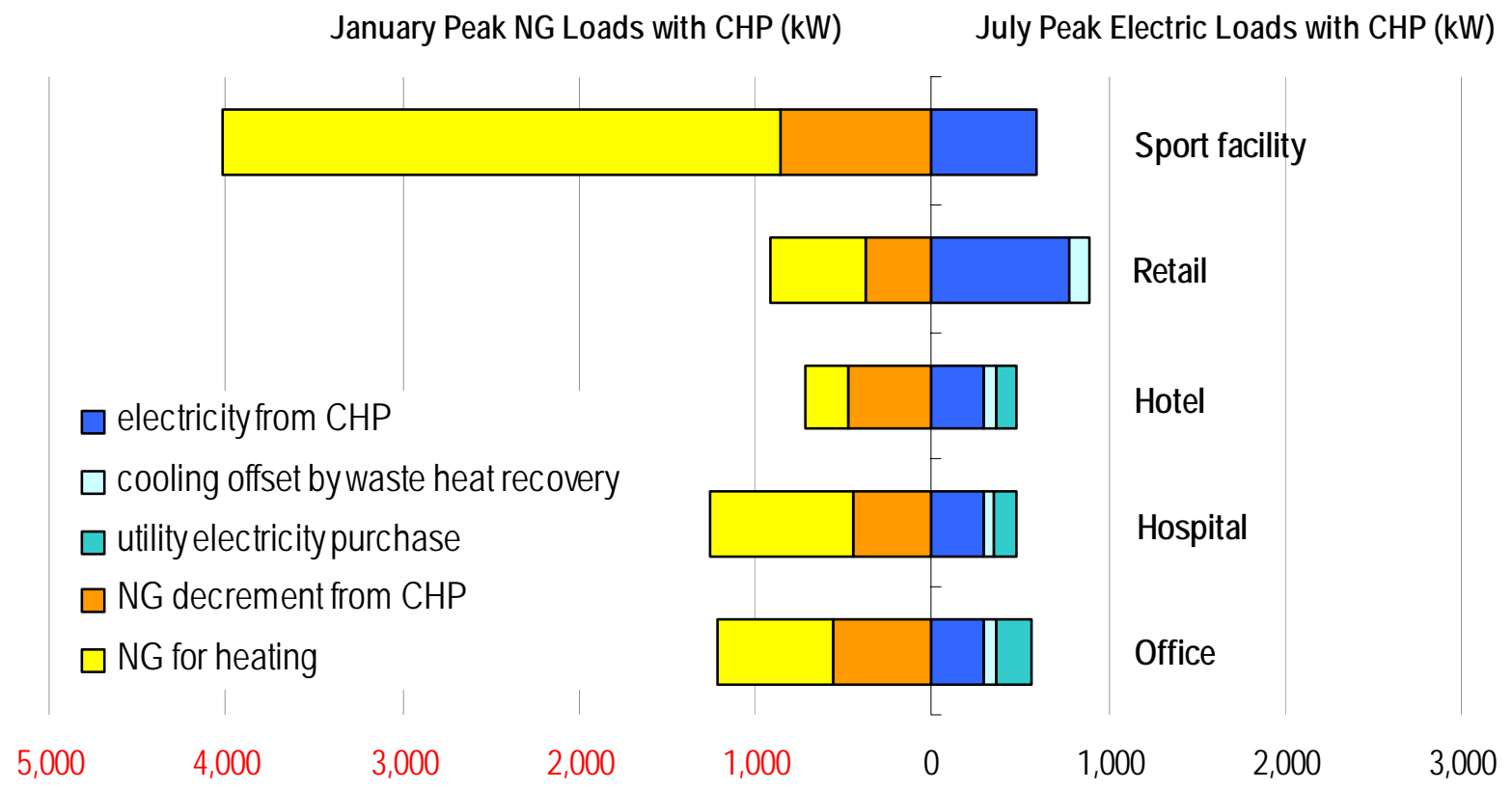

Figure 63: The Peak Load Shift Effect of Prototype Building

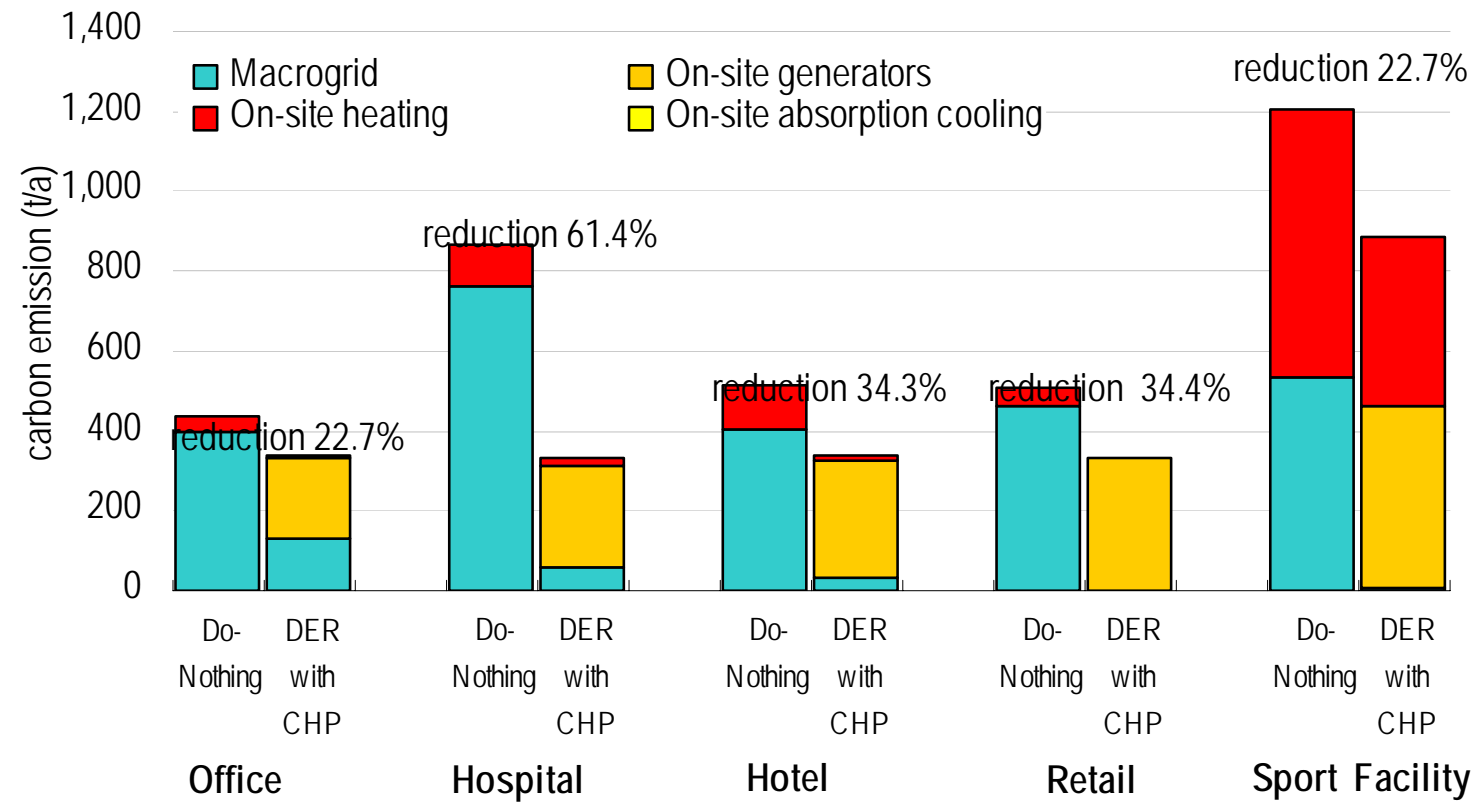

Figure 64 :The Effect of Prototype Building Carbon Emission Reduction 


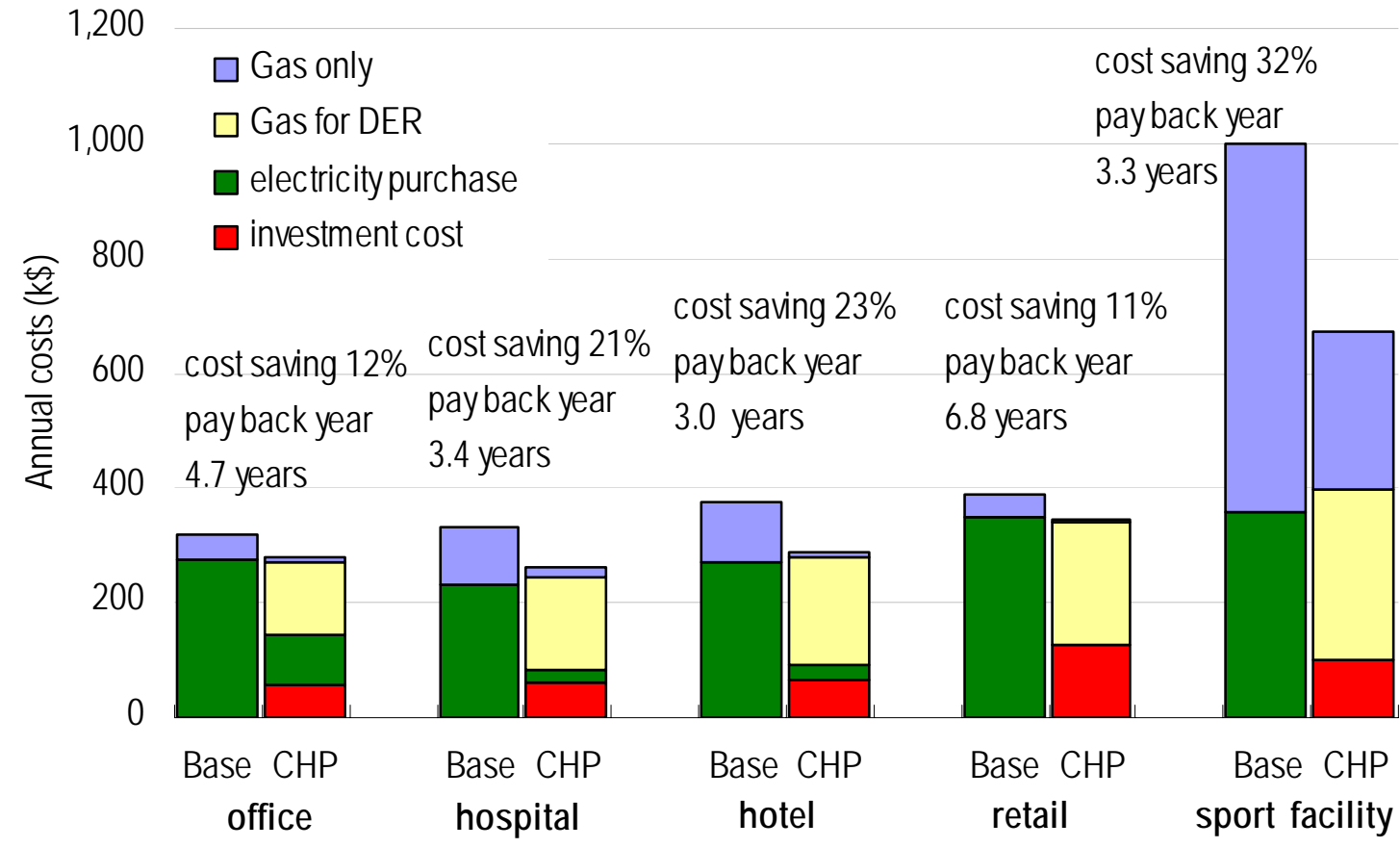

Figure 65: The Economic Effect of Prototype Building 



\section{$4.25,000 \mathrm{~m}^{2}$ Buildings}

All the above results are for $10,000 \mathrm{~m}^{2}$ buildings, but smaller buildings are also common. In this section, 5,000 $\mathrm{m}^{2}$ buildings of the same types were also evaluated to clarify the DER potential for smaller buildings. Loads are calculated from the building energy intensity, and Table 30 shows results. The hotel was the only building type to select DER in the DER without CHP scenario.

Table 30: Economic Results for 5000 m$^{2}$ Prototype Buildings

\begin{tabular}{|c|c|c|c|c|c|c|c|c|c|c|c|}
\hline & & & & & Annual Co & & & & & & \\
\hline Case & $\begin{array}{l}\text { Installed } \\
\text { Capacity }\end{array}$ & $\begin{array}{l}\text { Installed } \\
\text { Technology }\end{array}$ & Installation & Electricity & $\mathrm{Gas}$ & & Energy & Total & Energy Cost & Overall Cost & Pay Back \\
\hline & $\mathrm{kW}$ & & $\mathrm{k} \$$ & $\mathrm{k} \$$ & $\begin{array}{c}\text { For DER } \\
(\mathrm{k} \$)\end{array}$ & $\begin{array}{l}\text { Gas } \\
\text { only } \\
(\mathrm{k} \$)\end{array}$ & $\mathrm{k} \$$ & $\mathrm{k} \$$ & $\%$ & $\%$ & $\mathrm{a}$ \\
\hline Office & & & & & & & & & & & \\
\hline $\begin{array}{r}\text { Do- } \\
\text { Nothing }\end{array}$ & 0 & 0 & 0 & 137.6 & 0 & 21.1 & 158.7 & 158.7 & & & \\
\hline DER & 0 & 0 & 0 & - & - & - & - & - & - & - & - \\
\hline $\begin{array}{r}\text { DER with } \\
\text { CHP }\end{array}$ & 100 & $\begin{array}{c}\text { NG- } \\
\text { ARSHX-- } \\
00100\end{array}$ & 24 & 76.2 & 41 & 6.4 & 123.6 & 147.5 & $-22.1 \%$ & $-7 \%$ & 6 \\
\hline Hospital & & & & & & & & & & & \\
\hline $\begin{array}{r}\text { Do- } \\
\text { Nothing }\end{array}$ & 0 & 0 & 0 & 114.9 & 0 & 51.5 & 166.5 & 166.5 & & & \\
\hline DER & 0 & 0 & 0 & - & - & - & - & - & - & - & - \\
\hline $\begin{array}{r}\text { DER with } \\
\text { CHP }\end{array}$ & 100 & $\begin{array}{l}\text { NG--HX-- } \\
00100\end{array}$ & 20.4 & 55.6 & 49.2 & 11.1 & 115.8 & 136.2 & $-30.4 \%$ & $-18.2 \%$ & 2.7 \\
\hline Hotel & & & & & & & & & & & \\
\hline $\begin{array}{r}\text { Do- } \\
\text { Nothing }\end{array}$ & 0 & 0 & 0 & 173.6 & 0 & 19.7 & 193.3 & 193.3 & & & \\
\hline DER & 300 & NG--00300 & 35.4 & 32.3 & 104.1 & 14.9 & 151.3 & 186.6 & $-21.7 \%$ & $-3.4 \%$ & 5.6 \\
\hline $\begin{array}{r}\text { DER with } \\
\text { CHP }\end{array}$ & 300 & $\begin{array}{l}\text { NG-ARSHX- } \\
-00300\end{array}$ & 55.7 & 9 & 107.4 & 3.28 & 119.7 & 175.4 & $-38.1 \%$ & $-9.3 \%$ & 6.3 \\
\hline Retail & & & & & & & & & & & \\
\hline $\begin{array}{r}\text { Do- } \\
\text { Nothing }\end{array}$ & 0 & 0 & 0 & 134.5 & 0 & 52.8 & 187.3 & 187.3 & & & \\
\hline DER & 0 & 0 & 0 & - & - & - & - & - & - & - & - \\
\hline $\begin{array}{r}\text { DER with } \\
\text { CHP }\end{array}$ & 130 & $\begin{array}{c}1 \text { unit NG- } \\
\text { HX-0030 } \\
1 \text { unit NG- } \\
\text { ABSHX-- } \\
00100\end{array}$ & 35.2 & 30 & 83.5 & 4.32 & 117.86 & 153.03 & $-37.1 \%$ & $-18.3 \%$ & 3.3 \\
\hline Sports facility & & & & & & & & & & & \\
\hline $\begin{array}{r}\text { Do- } \\
\text { Nothing }\end{array}$ & 0 & 0 & 0 & 179.9 & 0 & 319.2 & 499.1 & 499.1 & & & \\
\hline DER & 0 & 0 & 0 & - & - & - & - & - & - & - & - \\
\hline $\begin{array}{r}\text { DER with } \\
\text { CHP }\end{array}$ & 300 & $\begin{array}{l}\text { NG--HX-- } \\
00300\end{array}$ & 49.88 & 1.3 & 147.2 & 139.7 & 288.1 & 338 & $-42.3 \%$ & $-32.3 \%$ & 1.6 \\
\hline
\end{tabular}


In the DER with CHP scenario, for the office building, at $100 \mathrm{~kW}$ natural gas engine with heat recovery for heating and cooling was selected. The total annual energy cost (including capital and maintenance costs) is reduced by $7 \%$ from the do nothing scenario. The payback period is 6 years. Total annual fuel costs are reduced by $22.1 \%$.

For the hospital, a $100 \mathrm{~kW}$ natural gas engine with heat recovery for heating was selected, reducing the total annual energy cost by $18.2 \%$ from the Do-Nothing scenario, with a payback period of 2.7 years. Total annual fuel costs are reduced by $30.4 \%$.

For the hotel, a $300 \mathrm{~kW}$ natural gas engine with heat recovery for heating and cooling is selected. Total annual energy costs are reduced by $9.3 \%$ and the payback period is 6.3 years. Total annual fuel costs are reduced by $38.1 \%$.

For the retail building, a $100 \mathrm{~kW}$ natural gas engine with heat recovery for heating and cooling and a $30 \mathrm{~kW}$ natural gas engine with heat recovery only for heating are selected. The total annual energy costs are reduced by $18.3 \%$. The payback period is 3.3 years. Total annual fuel costs are reduced by $37.1 \%$.

For the sports facility, a $300 \mathrm{~kW}$ natural gas engine with heat recovery for heating is selected. Total annual energy costs are reduced by $32.3 \%$ and the payback period is 1.6 years. Total annual fuel costs are reduced by $42.3 \%$.

Although the installation capacity is smaller than for $10,000 \mathrm{~m}^{2}$ buildings, CHP installations for smaller scale buildings still have significant economic benefits (Figure 66 and Figure 67). Sports facilities have the highest economic potential for CHP installation, followed by hotels.

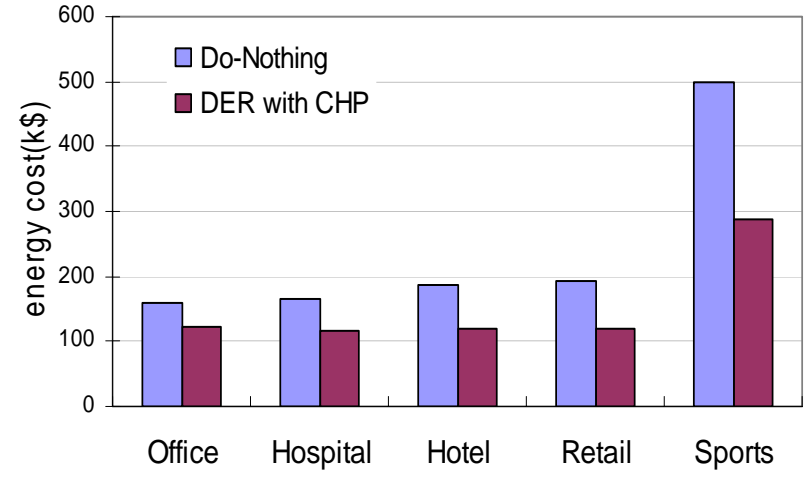

Figure 66: 5,000 $\mathrm{m}^{2}$ Building Total Annual Fuel Costs

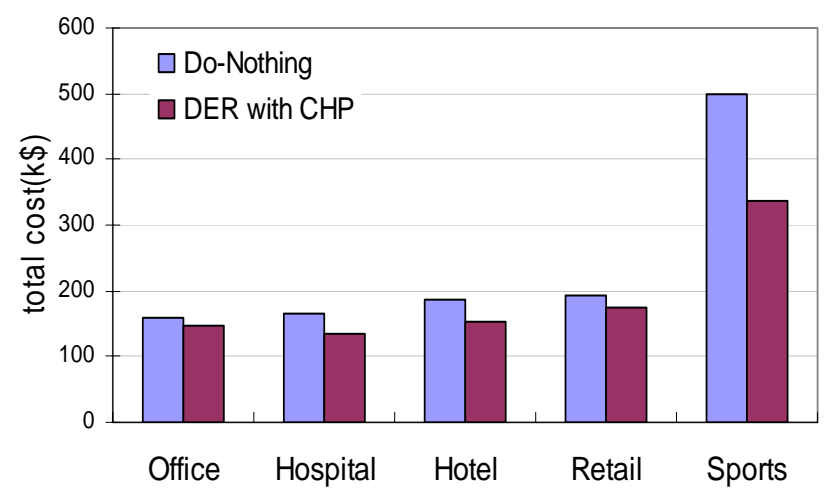

Figure 67: 5,000 $\mathrm{m}^{2}$ Building Total Annual Energy Costs 


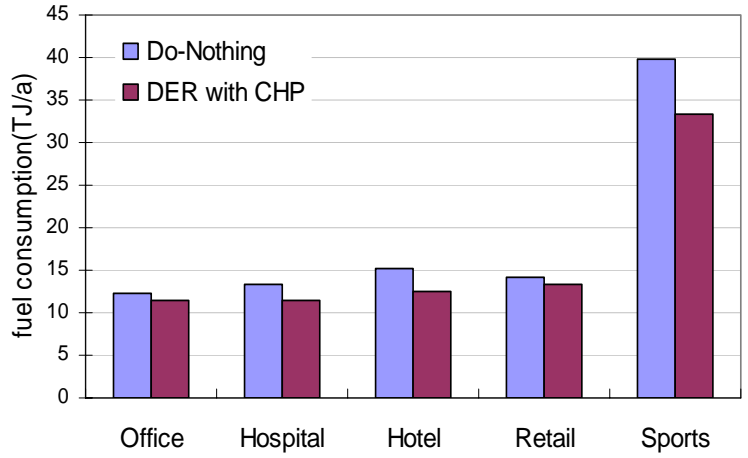

Figure 68 : 5,000 $\mathrm{m}^{2}$ Building Fuel Consumption

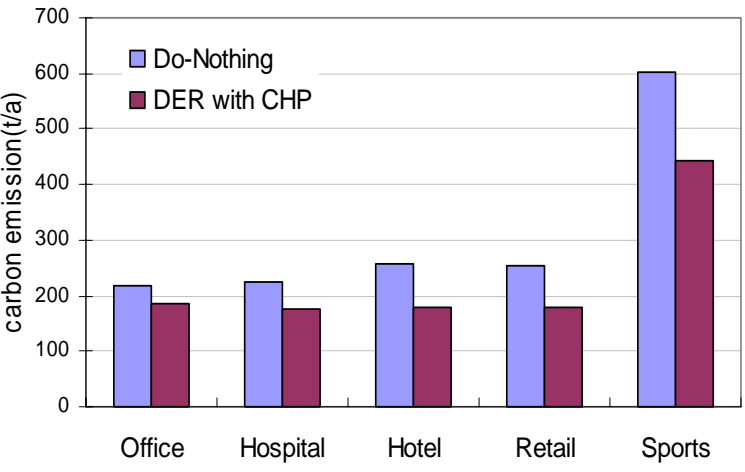

Figure 69: 5,000 $\mathrm{m}^{2}$ Building Carbon Emissions

Figure 68 and Figure 69 show energy conservation and carbon emissions for the 5,000 $\mathrm{m}^{2}$ buildings. For office buildings with CHP, fuel consumption is reduced by $6.5 \%$ and carbon emissions by $15.2 \%$. For the hospital, fuel consumption is reduced by $14.1 \%$ and carbon emissions by $21.6 \%$. For the hotel, fuel consumption is reduced by $18.2 \%$ and carbon emissions by $30.9 \%$. For the retail building, fuel consumption is reduced by $6.3 \%$ and carbon emissions by $28.5 \%$. For the sports facilities, fuel consumption is reduced by $16.4 \%$ and carbon emissions by 26.3\%. Sports facilities have the largest fuel and carbon reductions, followed by hotels.

As shown above, even for 5,000 $\mathrm{m}^{2}$ buildings, CHP adoption can have an economic benefit and result in fuel savings and carbon emission reductions.

Table 31: Fuel Consumption and Carbon Emissions for $5000 \mathrm{~m}^{2}$ Buildings

\begin{tabular}{|c|c|c|c|c|c|}
\hline & & \begin{tabular}{|l|} 
Fuel \\
Comsumption(TJ/a)
\end{tabular} & \begin{tabular}{|l|} 
Reduction from \\
Do-Nothing
\end{tabular} & \begin{tabular}{|l} 
Carbon \\
Emission(t/a)
\end{tabular} & \begin{tabular}{|l|} 
Reduction from \\
Do-Nothing
\end{tabular} \\
\hline \multirow[b]{2}{*}{ Office } & Do-Nothing & 12.37 & & 218.60 & \\
\hline & DER with $\mathrm{CHP}$ & 11.56 & $-6.5 \%$ & 185.39 & $-15.2 \%$ \\
\hline \multirow[b]{2}{*}{ Hospital } & Do-Nothing & 13.33 & & 224.20 & \\
\hline & DER with $\mathrm{CHP}$ & 11.45 & $-14.1 \%$ & 175.82 & $-21.6 \%$ \\
\hline \multirow[b]{2}{*}{ Hotel } & Do-Nothing & 15.21 & & 257.93 & \\
\hline & DER with $\mathrm{CHP}$ & 12.44 & $-18.2 \%$ & 178.12 & $-30.9 \%$ \\
\hline \multirow[b]{2}{*}{ Retail } & Do-Nothing & 14.20 & & 252.39 & \\
\hline & DER with $\mathrm{CHP}$ & 13.30 & $-6.3 \%$ & 180.56 & $-28.5 \%$ \\
\hline \multirow[b]{2}{*}{ Sports } & Do-Nothing & 39.79 & & 603.13 & \\
\hline & DER with CHP & 33.29 & $-16.4 \%$ & 444.31 & $-26.3 \%$ \\
\hline
\end{tabular}




\section{$4.3 \quad 10,000 M^{2}$ Buildings with Unsubsidized Technology Costs}

The analyses in Chapters 4 and 4.2 are based on the technology cost with the grants applied. The $10,000 \mathrm{~m}^{2}$ buildings were also examined with no DER equipment subsidy. This was done by increasing the DER capital costs by 50\%. Economic results are shown in Table 32, Figure 70, and Figure 71

Table 32: The Economic Results For Unsubsidized Technology Costs

\begin{tabular}{|c|c|c|c|c|c|c|c|c|c|c|c|}
\hline \multirow{2}{*}{ Case } & \multicolumn{11}{|c|}{ Annual Cost } \\
\hline & $\mathrm{kW}$ & & $\mathrm{K} \$$ & $\mathrm{~K} \$$ & $\begin{array}{c}\text { For } \\
\text { DER } \\
(\mathrm{k} \$)\end{array}$ & $\begin{array}{l}\text { Gas } \\
\text { only } \\
(\mathrm{k} \$) \\
\end{array}$ & $\mathrm{k} \$$ & $\mathrm{k} \$$ & $\%$ & $\%$ & $\mathrm{Y}$ \\
\hline \multicolumn{12}{|l|}{ Office } \\
\hline $\begin{array}{r}\text { Do- } \\
\text { Nothing }\end{array}$ & 0 & 0 & 0 & 275.3 & 0 & 42.1 & 317.4 & 317.4 & & & \\
\hline DER & 0 & 0 & 0 & - & - & - & - & - & - & - & - \\
\hline $\begin{array}{r}\text { DER with } \\
\text { CHP }\end{array}$ & 300 & $\begin{array}{c}\text { NG- } \\
\text { ABSHX-- } \\
00300\end{array}$ & 76.2 & 83.8 & 129.4 & 6.7 & 219.9 & 296.1 & $-30.7 \%$ & $-6.7 \%$ & 7 \\
\hline \multicolumn{12}{|l|}{ Hospital } \\
\hline $\begin{array}{r}\text { Do- } \\
\text { Nothing }\end{array}$ & 0 & 0 & 0 & 229.85 & 0 & 103.1 & 332.9 & 332.9 & & & \\
\hline DER & 0 & 0 & 0 & - & - & - & - & - & - & - & - \\
\hline $\begin{array}{r}\text { DER with } \\
\text { CHP }\end{array}$ & 300 & $\begin{array}{c}\text { NG--HX-- } \\
00300\end{array}$ & 62.4 & 62.1 & 135.9 & 17.9 & 215.9 & 278.3 & $-35.2 \%$ & $-16.4 \%$ & 4.5 \\
\hline \multicolumn{12}{|l|}{ Hotel } \\
\hline $\begin{array}{r}\text { Do- } \\
\text { Nothing }\end{array}$ & 0 & 0 & 0 & 268.9 & 0 & 105.7 & 374.6 & 374.6 & & & \\
\hline DER & 0 & 0 & 0 & - & - & - & - & - & - & - & - \\
\hline $\begin{array}{r}\text { DER with } \\
\text { CHP }\end{array}$ & 300 & $\begin{array}{c}\text { NG- } \\
\text { ABSHX-- } \\
00300 \\
\end{array}$ & 83.93 & 24.9 & 189.1 & 9.5 & 223.5 & 307.5 & $-40.3 \%$ & $-17.9 \%$ & 4.5 \\
\hline \multicolumn{12}{|l|}{ Retail } \\
\hline $\begin{array}{r}\text { Do- } \\
\text { Nothing }\end{array}$ & 0 & 0 & 0 & 268.9 & 0 & 105.7 & 374.6 & 374.6 & & & \\
\hline DER & 0 & 0 & 0 & - & - & - & - & - & - & - & - \\
\hline $\begin{array}{r}\text { DER with } \\
\text { CHP }\end{array}$ & 300 & $\begin{array}{l}\text { NG- } \\
\text { ABSHX-- } \\
00300\end{array}$ & 83.9 & 24.9 & 189.1 & 9.5 & 223.5 & 307.5 & $-40.3 \%$ & $-17.9 \%$ & 4.5 \\
\hline $\begin{array}{r}\text { Sports facilit } \\
\text { Do- } \\
\text { Nothing }\end{array}$ & ity & 0 & 0 & 359.8 & 0 & 638.7 & 998.1 & 998.1 & & & \\
\hline DER & 0 & 0 & 0 & - & - & - & - & - & - & - & - \\
\hline $\begin{array}{r}\text { DER with } \\
\text { CHP }\end{array}$ & 475 & $\begin{array}{c}\text { NG--HX- } \\
0075 \\
\text { NG--HX- } \\
00100 \\
\text { NG--HX- } \\
00300\end{array}$ & 114.2 & 29.8 & 277.1 & 278 & 584.9 & 699 & $-41.4 \%$ & $-30 \%$ & 2.1 \\
\hline
\end{tabular}




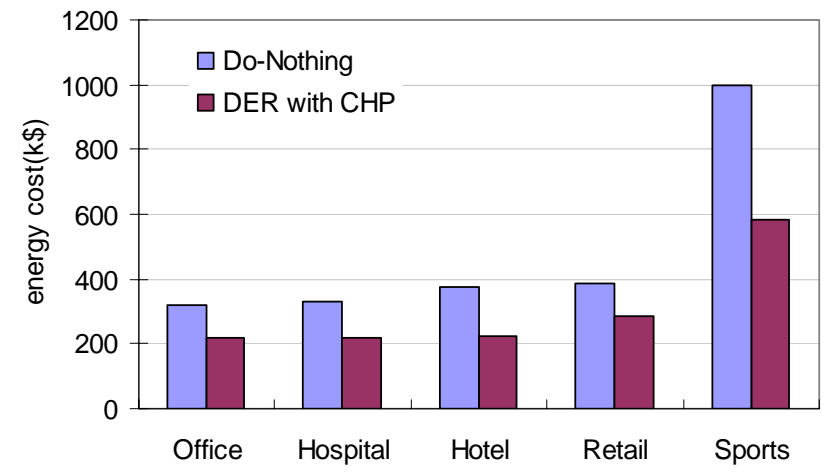

Figure 70: Total Annual Fuel Costs with Unsubsidized DER Capital Costs

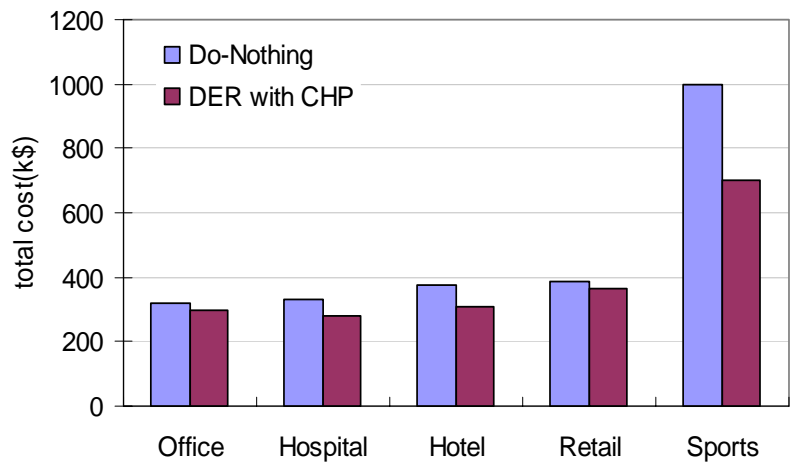

Figure 71: Total Annual Energy Costs with Unsubsidized DER Capital Costs

None of the prototype buildings invested in DER in the DER without CHP scenario. In the DER with CHP scenario, for the office building, a $300 \mathrm{~kW}$ natural gas engine with heat recovery for heating and cooling was selected. This reduces the total annual energy cost by $6.7 \%$. The payback period is 7 years. Total annual fuel costs are reduced by $30.7 \%$.

For the hospital, a $300 \mathrm{~kW}$ natural gas engine with heat recovery for heating was selected, resulting in a $16.4 \%$ reduction in total annual energy costs and a payback period of 4.5 years. Total annual fuels costs are reduced by $35.2 \%$.

For the hotel, a $300 \mathrm{~kW}$ natural gas engine with heat recovery for heating and cooling was selected, leading to a $17.9 \%$ reduction in total annual energy costs and a 4.5 year payback period. Total annual fuel costs are reduced by $40.3 \%$.

For the retail building, a $300 \mathrm{~kW}$ natural gas engine with heat recovery for heating and cooling was selected, resulting in a $6.3 \%$ reduction in total annual energy costs and a 4.5 year payback period. Total annual fuel costs are reduced by $25.6 \%$.

For the sports facility, three natural gas engines with heat recovery for heating are selected: 300 $\mathrm{kW}, 100 \mathrm{~kW}$, and $75 \mathrm{~kW}$. These investments lead to a 30\% reduction in total annual energy costs and a 2.1 year payback period. Total annual fuel costs are reduced by $41.4 \%$.

Figure 72, Figure 73, and Figure 33 show fuel consumption and carbon emissions. For office buildings with CHP installation fuel consumption is reduced by $8.2 \%$ and carbon emissions by $22.7 \%$. For the hospital, fuel consumption is reduced by $13.7 \%$ and carbon emissions by $25.7 \%$. For the hotel, fuel consumption is reduced by $18.7 \%$ and carbon emissions by $34.3 \%$. For the retail building, fuel consumption is reduced by $7.6 \%$ and carbon emissions by $18.9 \%$. For sports facilities, fuel consumption is reduced by $16.2 \%$ and carbon emissions by $25.3 \%$. Sports facilities have the most significant effect, followed by hotels. 


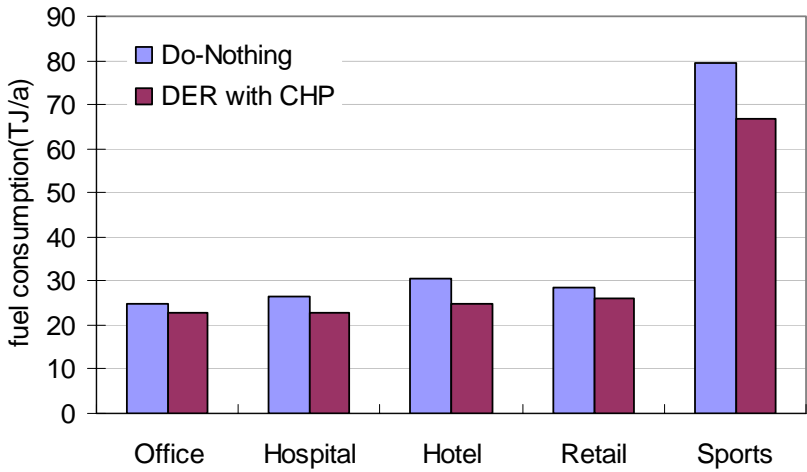

Figure 72: Total Annual Fuel Consumption with Unsubsidized DER Capital Costs

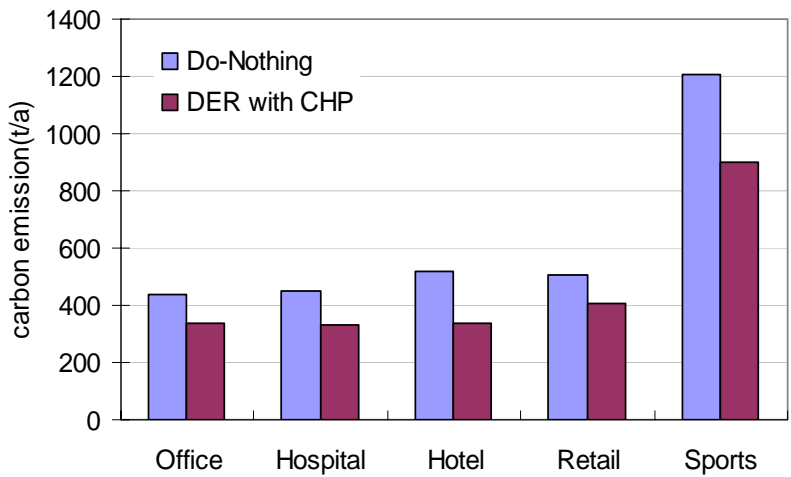

Figure 73: Total Annual Carbon Emissions With Unsubsidized DER Capital Costs

Table 33: Total Annual Fuel Consumption and Carbon Emission for the $10,000 \mathbf{~ m}^{2}$ Buildings with Unsubsidized DER Capital Costs

\begin{tabular}{|c|c|c|c|c|c|}
\hline & & $\begin{array}{l}\text { Fuel } \\
\text { Comsumption(TJ/a) }\end{array}$ & $\begin{array}{l}\text { from } \\
\text { Do-Nothing }\end{array}$ & $\begin{array}{l}\text { Carbon } \\
\text { Emission(t/a) }\end{array}$ & $\begin{array}{l}\text { Reduction from } \\
\text { Do-Nothing }\end{array}$ \\
\hline \multirow[b]{2}{*}{ Office } & Do-Nothing & 24.74 & & 437.19 & \\
\hline & DER with CHP & 22.71 & $-8.2 \%$ & 338.14 & $-22.7 \%$ \\
\hline \multirow[b]{2}{*}{ Hospital } & Do-Nothing & 26.65 & & 448.41 & \\
\hline & DER with CHP & 23.01 & $-13.7 \%$ & 333.23 & $-25.7 \%$ \\
\hline \multirow[b]{2}{*}{ Hotel } & Do-Nothing & 30.42 & & 515.86 & \\
\hline & DER with CHP & 24.73 & $-18.7 \%$ & 338.94 & $-34.3 \%$ \\
\hline \multirow[b]{2}{*}{ Retail } & Do-Nothing & 28.39 & & 504.78 & \\
\hline & DER with CHP & 26.24 & $-7.6 \%$ & 409.15 & $-18.9 \%$ \\
\hline \multirow[b]{2}{*}{ Sports } & Do-Nothing & 79.59 & & 1206.26 & \\
\hline & DER with CHP & 66.73 & $-16.2 \%$ & 900.92 & $-25.3 \%$ \\
\hline
\end{tabular}

As shown above, even without subsidy, all prototype buildings can benefit significantly from CHP installation as fuel consumption and environmental load reduction effects.

Compared to the cases with DER subsidy, installed CHP systems are smaller, as are the resulting effects. 


\section{Conclusions}

This research used DER-CAM to examine the potential for cogeneration in different Japanese prototype buildings.

Chapter 1 described the research background and purpose.

Chapter 2 described the related research regarding CHP assessment and details of DER-CAM.

Chapter3 described the DER-CAM structure and input data. For building energy consumption data, DOE2 was used for office building simulation and the results were compared with the load data used in Japan. Also, comparisons of fuel tariffs (electricity and natural gas) between Japan and the United States were made. Commercial electricity tariffs in the two countries are similar. However, the commercial natural gas tariffs in Japan are higher than in the United States.

Furthermore, differences in DG technology information between the two countries were discussed. In Japan, small-scale CHP installation costs are almost twice as much as in the United States, but this difference shrinks as CHP size increases. For large CHP system size, capital costs are lower in Japan than in the United States.

A comparison of DG subsidies in the two countries has also been made. In Japan, 1/3 of the capital costs of CHP systems is covered by subsidy. In the United States, subsidies vary by region. Subsidies range from $20 \%$ to $90 \%$.

Chapter 4 presents results from the examination 10,000 $\mathrm{m}^{2}$ office buildings, hotel, hospital, retail store and sports facility prototype buildings. Economically optimal DER investment for each was determined, and the resulting the annual energy cost savings, fuel savings, and carbon emissions reductions are quantified. The economic and environmental effect of CHP installation can be seen. Even though these studies conduct cost optimizations, fuel consumption and carbon emissions are noticeably reduced.

Sports facilities can benefit the most from CHP, followed by hospitals and hotels. Even for office buildings, which have not been considered in existing studies for CHP potential, CHP adoption potential is shown. For hospitals and sports facilities, using recovered heat for heating is effective. For the other buildings, using recovered heat for both heating and cooling is most effective.

Chapter 5 presents results from the examination of $5,000 \mathrm{~m}^{2}$ buildings. DER installation capacity is smaller than for the $10,000 \mathrm{~m}^{2}$ buildings, and payback periods are longer, but there are still economic, energy, and carbon emissions savings.

Chapter 6 presents results for the 10,000 $\mathrm{m}^{2}$ buildings without DER equipment subsidy. Even without subsidy, economic, energy, and carbon emissions savings are seen, although the magnitudes of the reductions are decreased. 



\section{References}

ANRE, Japan. 2004. The Energy and Resources Today, Agency for Natural Resources and Energy, http://www.meti.go.jp/report/downloadfiles/g01011gj.pdf

Bailey,Owen, Charles Creighton, Ryan Firestone,Chris Marnay, and Michael Stadler, 2003. Distributed Energy Resources in Practice: A Case Study Analysis and Validation of LBNL's Customer Adoption Model, LBNL -52753

Firestone, R. Distributed Energy Resources Customer Adoption Model Technology Data, Berkeley Lab, Berkeley, CA, January, 2004. Available online at http://der.lbl.gov/data/DERCAMTechDataOnline.pdf, http://www.cpuc.ca.gov/published/report/13690.htm and San Diego Regional Energy Office, San Diego SELFGEN Program Frequently Asked Questions, http://www.sdenergy.org/docs/SELFGEN_FAQs.pdf

Japan Ministry of the Environment, 2001. Estimation of Greenhouse Gas Emission in Residential and Commercial Sector, http://www.env.go.jp/earth/report/h12-03/4-4-2-1.pdf

Kashiwagi,Takao, 2002. Natural Gas Cogeneration Plan/ Design Manual 2002, Japan Industrial Publishing Co.,LTD

Matsuo, Yo, et al. 1980. An Introduction to Calculations for HVAC Dynamic Thermal Load, The Society of Heating,Air-Conditioning and Sanitary Engineers of Japan.

METI, Japan.2004. Trend of energy consumption in residential and commercial sector, The Ministry of Economy, Trade and Industry (METI), http://www.enecho.meti.go.jp/english/energy/index.html

Ministry of Environment, http://www.env.go.jp/council/06earth/r062-01/index.html.

Nagai, Tasuo. 2001. Optimized HVAC Operation Considering Building Thermal Storage and Analysis of the Effect on Energy Consumption, Journal of Architecture,Planning and Environmental Engineering, AIJ, No.540, pp. 45-52

NEGA, Japan Enegine Generator Association, http://www.nega.or.jp/

Nishida, Masaru, et al. 1997. Comprehensive Research on the Utilization of Un-utilized Energy in Building and Urban Scale in Kyushu Area, Report of JSPS 1995-1997 Grants-in-Aid for Scientific Research, pp. 78-81

Okuda, Hidenobu, et al. 2002. Evaluation of Cogeneration System Based on Performance Test Results of a Micro Gas Turbine, The Japan Society of Mechanical Engineers, No.02-7, The 8th National Symposium on Power and Energy Systems, pp.43-46

Source CPUC Self-Generation Incentive Program July-December 2001 Status Report,

The Ministry of Construction (present Ministry of Land, Infrastructure and Transport), Japan. 2000. Construction Data and Statistics Annual Report

DOE 2000. DOE-2 Program Manual

Yamaguchi, Yohei, et al. 2003. Development of District Energy System Simulation Model Based On Detailed Energy Demand Model, Proceeding of Eighth International IBPSA Conference, Eindhoven,Netherlands, pp.1443-1450

Yamaguchi, Yohei, et al.2003. Simulation of heat supply network connecting distributed cogeneration system and buildings, Proceeding of The 22th Annual Meeting Proceeding of The Japan Society of Energy and Resources, pp123-128 